\title{
Treatment of Hydrocarbon, Organic Residue and Production Chemical Damage Mechanisms Through the Application of Carbon Dioxide in Natural Gas Storage Wells
}

\author{
Final Report \\ 1 October 1999 - 30 September 2003
}

\author{
Submitted By: \\ Advanced Resources International \\ Stimlab, Inc. \\ Submission Date: \\ June 30, 2004
}

DOE Award Number:

DE-FC26-99FT-40702

\author{
Submitting Organizations: \\ Advanced Resources International, Inc. \\ 4501 Fairfax Drive, Suite 910 \\ Arlington, VA 22203 \\ Stimlab, Inc. \\ 7406 N. Highway 81 \\ Duncan, OK 73533
}




\section{Disclaimer}

This report was prepared as an account of work sponsored by an agency of the United States Government. Neither the United States Government nor any agency thereof, nor any of their employees, makes any warranty, expressed or implied, or assumes any legal liability or responsibility for the accuracy, completeness, or usefulness of any information, apparatus, product or process disclosed, or represents that its use would not infringe privately owned rights. Reference herein to any specific commercial product, process, or service by trade name, trademark, manufacturer, or otherwise does not necessarily constitute or imply its endorsement, recommendation or favoring by the United States Government or any agency thereof. The views and opinions of authors expressed herein do not necessarily state or reflect those of the United States Government or any agency thereof. 


\begin{abstract}
Two gas storage fields were studied for this project. Overisel field, operated by Consumer's Energy, is located near the town of Holland, Michigan. Huntsman Storage Unit, operated by Kinder Morgan, is located in Cheyenne County, Nebraska near the town of Sidney. Wells in both fields experienced declining performance over several years of their annual injection/production cycle. In both fields, the presence of hydrocarbons, organic materials or production chemicals was suspected as the cause of progressive formation damage leading to the performance decline.

Core specimens and several material samples were collected from these two natural gas storage reservoirs. Laboratory studies were performed to characterize the samples that were believed to be representative of a reservoir damage mechanism previously identified as arising from the presence of hydrocarbons, organic residues or production chemicals. A series of laboratory experiments were performed to identify the sample materials, use these materials to damage the flow capacity of the core specimens and then attempt to remove or reduce the induced damage using either carbon dioxide or a mixture of carbon dioxide and other chemicals.

Results of the experiments showed that pure carbon dioxide was effective in restoring flow capacity to the core specimens in several different settings. However, in settings involving asphaltines as the damage mechanism, both pure carbon dioxide and mixtures of carbon dioxide and other chemicals provided little effectiveness in damage removal.
\end{abstract}




\section{Table of Contents}

Executive Summary ..........................................................................................................1

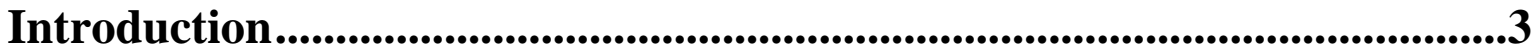

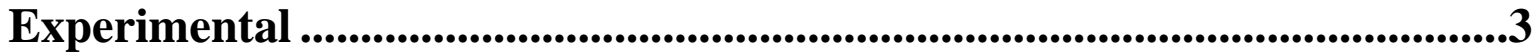

Fields and Samples Studied....................................................................................4

Huntsman Storage Field...................................................................................................4

Overisel Storage Field.....................................................................................................5

Basic Sample Analysis Procedure.....................................................................................5

Laboratory Flow Studies- Core Sample ...........................................................................6

Laboratory Flow Studies- Fractured Sample ....................................................................8

Results and Discussion............................................................................................11

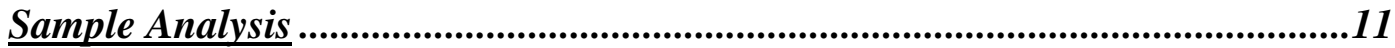

Hydrocarbon Profiling.................................................................................................12

Laboratory Flow Studies....................................................................................................13

Conclusions ............................................................................................................... 31

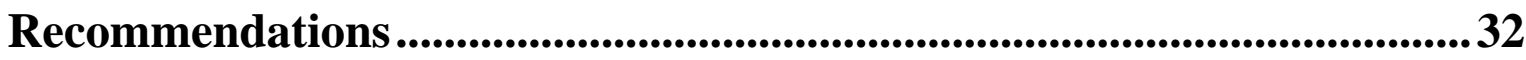

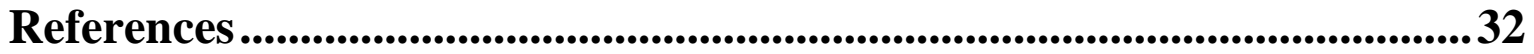

List of Acronyms and Abbreviations ......................................................32

Appendix A - Huntsman Storage Well Sample Analyses...........................A-1

Appendix B - Petrographic Analysis of Selected Samples from the Huntsman Storage Well \#26 ............................................................. B-1

Appendix C - Petrographic Analysis of the A-2 Carbonate from the Overisel Storage Field........................................................................ C-1

"Treatment of Hydrocarbon, Organic Residue and Production Chemical Damage Mechanisms Through the Application of Carbon Dioxide in Natural Gas Storage Wells” 


\section{Table of Tables}

Table 1 - Bailed Samples from the Huntsman Storage Field

\section{Table of Figures}

Figure 1 - Flow-By Open Face Core Holder Used in Flow Studies ..............................7

Figure 2 - Flow Diagram...........................................................................................9

Figure 3 - Preparation of Fractured Overisel Core Sample............................................10

Figure 4 - Hydrocarbon Profile of Native Crude, Huntsman Storage Field ...............14

Figure 5 - Hydrocarbon Profile of Compressor Oil, Huntsman Storage Field ..........15

Figure 6 - Hydrocarbon Profile of Valve Grease, Huntsman Storage Field................16

Figure 7 - Hydrocarbon Profiles for Huntsman Samples................................................17

Figure 8 - Damage Removal Core Flood Study, HS \#21.............................................19

Figure 9 - Damage Removal Core Flood Study, HS \#10.......................................19

Figure 10 - Damage Removal Core Flood Study, HS \#30................................................21

Figure 11 - Damage Removal Core Flood Study, HS \#44................................................21

Figure 12 - Results of Core Flood Study to Deposit Asphaltene in Cracked A-2 Carbonate Core, First Attempt...........................................23

Figure 13 - Results of Core Flood Study to Deposit Asphaltene in Cracked A-2 Carbonate Core, Second Attempt..........................................24

Figure 14 - Attempt to Remove Asphaltene Damage with Pac-91 Solvent and Liquid CO2, Third Attempt ......................................................................225

Figure 15 - Attempt to Remove Asphaltene Damage with Cleartene 153 Solvent and Liquid CO2 ..............................................................................26

Figure 16 -Pressure Response During Repetitive Cleartene 153 Injections

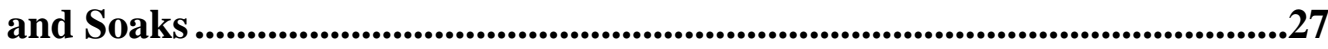

Figure 17 - Preparation of Test Core With Groove....................................................27

Figure 18 - Attempt to Remove Asphaltene from Grooved Fractured Core Mixture of Cleartene and $\mathrm{CO} 2$............................................................................28

Figure 19 - Attempt to Remove Asphaltene from Grooved Fractured Core Mixture of PAC-91 and CO2

Figure 20 - Attempt to Remove Asphaltene from Grooved Fractured Core Mixture of LS-489 and CO2

Figure 21 - Test to Remove Asphaltene from Grooved Fractured Core Mixture of LS-489 and CO2 Repeat

"Treatment of Hydrocarbon, Organic Residue and Production Chemical Damage Mechanisms Through the Application of Carbon Dioxide in Natural Gas Storage Wells” 


\section{Executive Summary}

Two gas storage fields were studied for this project. Overisel field, operated by Consumer's Energy, is located near the town of Holland, Michigan. Huntsman Storage Unit, operated by Kinder Morgan, is located in Cheyenne County, Nebraska near the town of Sidney. Wells in both fields experienced declining performance over several years of their annual injection/production cycle. In both fields, the presence of hydrocarbons, organic materials or production chemicals was suspected as the cause of progressive formation damage leading to the performance decline.

The operators provided potentially damaging materials such as valve grease, compressor oil and native oil from their respective fields. These samples were collected from a variety of sources, including bottomhole samples from several wells, surface flowlines and facility inventories of commercial products used at the fields. The operators also provided from their inventories whole core specimens for analysis.

Suspected damage materials were bailed from a total of 12 Huntsman wells. The samples were quite variable in their appearance and thus similar samples were grouped together and representative selections were analyzed. Hydrocarbon components were separated from the samples of five wells and characterized using chromatography. These profiles were compared to hydrocarbon profiles obtained from Huntsman native crude oil, valve grease and compressor lubricating oil used at the facility. Results indicated that weathered crude was present in four of the five wells, valve grease was present in two of the five wells and compressor oil in two of the five wells.

Core plugs were cut from whole core that originated from Huntsman well \#26 at a depth of 4,861 feet. An air permeability of 249 md was measured, which was consistent with earlier pressure transient analysis results from the field. A core plug was damaged with valve grease, reducing the permeability to only $33 \mathrm{md}$. Super-critical carbon dioxide was then injected into the core, which removed the damage and restored the core to $95 \%$ of its original permeability. The experiment was repeated using damage material recovered from well \#21, with essentially the same result.

A similar experiment was performed using damage material recovered from well \#10, believed to be a mixture of weathered crude and compressor oil. The experiment reduced the permeability of the core to $18 \%$ of its original value. Treatment with super-critical carbon dioxide was again successful in restoring the damaged sample's permeability. This experiment was repeated with another core plug that was damaged with similar material retrieved from well \#30. Again, treatment with super-critical carbon dioxide removed the damage.

At the Overisel storage field, damage materials collected from surface flowlines included asphaltines, sludge and minor amounts of crude oil. Analysis of core plugs from the Overisel storage formation, the A-2 dolomite yielded an air permeability of $0.1 \mathrm{md}$. This

"Treatment of Hydrocarbon, Organic Residue and Production Chemical Damage Mechanisms Through the Application of Carbon Dioxide in Natural Gas Storage Wells” 
suggests that most flow capacity in the field exists within natural fractures, which is consistent with previous well test and hydraulic fracturing experience at the field. To replicate this condition, the cores were artificially fractured to provide adequate flow capacity.

A first series of experiments were attempted to damage the core with sludge that was assumed to have a high content of asphaltines. However, these attempts to create damage in the core were unsuccessful and further testing revealed that the sludge was actually an aqueous-based micro-emulsion.

A second series of experiments used other damage material samples contained up to $60 \%$ asphaltine solids and the use of this material reduced the induced fracture permeability from approximately 2 darcies down to 97 millidarcies. Injection of supercritical $\mathrm{CO}_{2}$ was unsuccessful in removing this damage. Repeated experiments using a variety of commercial solvents, some in combination with $\mathrm{CO}_{2}$, also failed to efficiently remove the asphaltine damage. Some damage removal was observed in high injection rate tests, but this appeared to be due to erosion of the damage material with high flowing velocity, rather than dissolution of the damage.

Characterization of bottomhole materials collected from Huntsman field demonstrated that contamination from surface materials such as valve grease and compressor oil is common in the field. Degraded crude oil is also a common constituent in Huntsman wells. These materials can effectively damage the productive formation, but supercritical $\mathrm{CO}_{2}$ is very effective in laboratory scale experiments in removing such damage. The results are directly relevant to the project objectives of determining the suitability of $\mathrm{CO}_{2}$ as a remediation fluid for hydrocarbon-based damage. These results further suggest that design and execution of a field demonstration to test the technology is justified.

Not all hydrocarbon-based damage is suitable for remediation by a $\mathrm{CO}_{2}$-based treatment, as suggested by experimental results from Overisel field specimens. Dried asphaltine was difficult to remove with either pure $\mathrm{CO}_{2}$ or in combination with commercial chemicals solvents. These results suggest that design and execution of a field-scale test for asphaltine removal is not justified. 


\section{Introduction}

Hydrocarbons, organic residues and production chemicals (HOPC) can occur in almost any gas storage well environment. This is true because there are the two sources of HOPC, fluids introduced from the surface and naturally occurring hydrocarbons within the reservoir, that is, oil and/or condensate. Naturally occurring hydrocarbons are present in many storage reservoirs since most storage facilities originally were producing oil or gas fields that were later converted for gas storage use. However, the introduction of HOPC from the surface can occur at any storage facility and in some cases, such as corrosion inhibitor squeeze treatments, are injected into the wells intentionally. Thus the presence of HOPC damage in storage wells is not strongly dependent upon lithology, structure or depth. However, interaction between introduced fluids and reservoir fluids, formation wetability and the reservoir's temperature are contributing factors to the creation of HOPC damage.

The primary focus of this research project is directed toward developing an effective remediation treatment for HOPC damage using the application of carbon dioxide $\left(\mathrm{CO}_{2}\right)$ as the primary treating fluid. The use of $\mathrm{CO}_{2}$ in this capacity and its probability of success is supported by several lines of evidence. $\mathrm{CO}_{2}$ is well known for its ability to mobilize and displace hydrocarbons and is used extensively in enhanced oil recovery operations. A significant body of work on the subject exists. This property may be put to good use in efforts to remove hydrocarbon based damage in wells.

Less well known is the developing record of the use of $\mathrm{CO}_{2}$ in gas storage wells. In DOE supported work performed by Advanced Resources International under DE-AC2194MC31112 "Field Application of New and Novel Fracture Stimulation Technologies for The Revitalization of Natural Gas Storage Wells" several storage wells have been hydraulically fractured with liquid $\mathrm{CO}_{2}$ and sand proppant ${ }^{1}$. The success of these treatments appears to have been in part due to the solvent capability of $\mathrm{CO}_{2}$ in addition to the placement of proppant within the storage horizon. Reports from the field indicated that some of these wells, wells that produced small volumes of hydrocarbons naturally, produced back a slug of hydrocarbons during cleanup operations. The suggestion is clear that the application of $\mathrm{CO}_{2}$ may be a promising means of treating $\mathrm{HOPC}$ related damage.

Finally, $\mathrm{CO}_{2}$ and its usage is familiar in the oil and gas service industry and among storage operators. If successful, this familiarity will allow more rapid acceptance and use by the storage industry.

\section{Experimental}

Laboratory studies were conducted to characterize the field rock samples in order to identify potential geochemical incompatibilities with suspected damaging materials and/or chemicals to be used to remove damaging materials. This characterization process

"Treatment of Hydrocarbon, Organic Residue and Production Chemical Damage Mechanisms Through the Application of Carbon Dioxide in Natural Gas Storage Wells” 
also yielded information regarding whether the damage was near wellbore or deep matrix damage and how treatments to remove such damage should be designed.

Additionally, characterization of the damaging materials was required in order to identify composition and their potential sources. Evaluative treatments were then designed for those components suspected of creating the permeability damage. This was conducted through laboratory scale studies with field formation rock samples to evaluate the effectiveness of various treatments at removing damage, requiring ingenuity with regard to experimental design.

\section{Fields and Samples Studied}

Advanced Resources International solicited field samples from various gas storage fields that met the criteria outlined in the program solicitation. Two operators agreed to provide samples and background information as available for the study. These operators were Kinder Morgan, Inc. operator of the Huntsman Field in Cheyenne County Nebraska, and Consumers Energy operator of the Overisel Storage Field, Overisel, Michigan.

Huntsman Storage Field - Kinder-Morgan provided approximately six feet of remnant whole library core from storage well \#26. A large amount of relative permeability or special core analysis data was generated on these samples by Core Laboratories (parent company of Stim-Lab, Inc.) ${ }^{2,3,4,5}$. However, only a few portions of the core were still suitable for further core flood analysis, most having been utilized in the referenced studies. Those available for study were cored near 4,861 feet, with exact depths unknown due to poor core sample organization within the core box.

At Huntsman, it is believed that the cyclic gas injection is creating a drying effect near the wellbore due to the the large volumes of dry gas injected. This continual drying effect leads to deposition of non-volatile components that accumulate from cycle to cycle within the storage wells. Typical remedial treatments have been circulating the wellbore free of debris and acidizing. In some cases these treatments are minimally effective. However, the exact damage mechanism is not known in every case and it is suspected that contamination of the injection gas by man-induced materials on the surface may be responsible in combination with the formation drying and native crude production (weathering).

So, twelve bailed samples were submitted in bottles from various wells. The composition of which varied The twelve samples were grouped by appearance and those that were deemed too small for analysis (five samples) were removed from further study, leaving seven samples of sufficient quantity and differing appearance for further work. These samples were from wells \#7, \#8, \#10, \#21, \#23, \#30 and \#44. . In addition, Kinder-Morgan supplied samples of commonly used chemicals, produced native crude, and lubricants for analysis comparison to the bailed materials. 
Overisel Storage Field - Overisel samples included a 5 inch long section of 4 inch whole core in two pieces from the A-2 carbonate, which was obtained through a core sample provider. No well identification or depth was provided with the whole core sample. However, the supplier expressed that the sample was representative of the storage zone.

The primary damage mechanism at the Overisel storage field is believed to consist of an asphaltene sludge, which is recovered each spring prior to the beginning of gas injection during line pigging of the surface lines. Since the storage wells produce some native crude when on winter production, it is believed that asphaltene is being deposited during production and dried in place during the gas injection cycle. Thus, the slow buildup of asphaltene deposits near the wellbore is reducing well injectivity/productivity. Further, conventional solvent treatments have been ineffective on dried and hardened deposits.

A pigged hydrocarbon sample representative of the hydrocarbon that accumulates in the surface lines during winter production stage was provided. At a later date two more pigged samples were submitted.

\section{Basic Sample Analysis Procedure}

1. Samples as received were mixed thoroughly as possible to give uniformity. Moisture and volatile content was analyzed with a 10-20 gram portion of the sample. The portion was placed in a tared crucible and weighed to four decimal places on an analytical balance. The sample was heated in stages starting at $35^{\circ} \mathrm{C}$ for one hour, then $65{ }^{\circ} \mathrm{C}$ for one hour then to $100{ }^{\circ} \mathrm{C}$ to a stable dry weight. The weight loss was calculated as a percentage of the original weight and reported as moisture and volatile content. This content would be expected to be lost during injection of dry gas and was not considered to contribute to the damage mechanism.

2. The sample was then split into four portions and one portion weighed to four decimal places in a tared beaker to which was added $100 \mathrm{ml}$ of xylene (a common solvent used in the wellbore cleanout). The sample was heated to $35{ }^{\circ} \mathrm{C}$ and mixed for 20 minutes. The solution was then filtered through a preweighed Whatman 42 paper, solids washed with additional hot xylene, and placed in a 90 ${ }^{\circ} \mathrm{C}$ oven to a stable weight. The weight loss was calculated as a percentage of the original sample weight and reported as percentage that was xylene soluble.

3. Step 2 was repeated with another portion from step 1 with hexane as the solvent. The weight loss was calculated as percentage of the original sample weight and reported as percentage that was hexane soluble (hexane will not solubilize asphaltene).

4. One half of the remaining solids from step 3 were weighed accurately to four decimal places in a tared beaker and mixed with an excess of $15 \%$ hydrochloric ( $\mathrm{HCl})$ acid. These were placed in a $65{ }^{\circ} \mathrm{C}$ water bath and covered with a watch glass. The mixture was swirled every $10 \mathrm{~min}$ for one hour. The beaker was

"Treatment of Hydrocarbon, Organic Residue and Production Chemical Damage Mechanisms Through the Application of Carbon Dioxide in Natural Gas Storage Wells” 
removed and placed in a room temperature water bath to cool. The solution was then filtered through a preweighed Whatman 42 filter paper and rinsed with deionized (DI) water, placed in a $90{ }^{\circ} \mathrm{C}$ oven to a stable weight. The weight loss of the sample was calculated as a percentage of the initial sample weight and reported as percentage of $\mathrm{HCl}$ soluble.

5. The third portion of the sample from step 1 was then analyzed for paraffin content using procedure described in API RP 34 sec 3.

6. One half of the solids from step 3 (total solids including acid soluble portion) and the remaining solids from step 4 ( $\mathrm{HCl}$ acid insoluble portion) were analyzed by $\mathrm{x}$ ray diffraction spectroscopy to identify the crystalline minerals present and to determine their relative abundance.

7. Finally the fourth portion from step one was accurately weighed in a tared beaker to which was added $100 \mathrm{ml}$ of DI water and mixed thoroughly and centrifuged. A $50 \mathrm{ml}$ portion of the supernate was titrated for chloride content and the content reported as a percentage salt concentration based on on initial sample weight.

\section{Laboratory Flow Studies- Core Sample}

1. The core sample is initially vacuum-saturated in $2 \%$ potassium chloride $(\mathrm{KCl})$ brine.

2. The core sample is mounted in core holder (Figure 1) with full open flow head on "wellbore" end (dynamic flow-by cell). This core holder was used for all flow studies and uses a rubber confinement sleeve pressurized with nitrogen gas to constrain a one inch diameter core plug and prevent flow around the plug. The design of the cell exposes the entire surface area of one end of the core. The cell is normally used for dynamic deposition of mud or gel filter cakes in simulation of drilling or hydraulic fracturing treatments. The void space at the end of the core allows for build-up of mud or filter cake. In these studies the void space is used for application of the bailed materials to evaluate the potential damage that is created. The materials are applied manually by removing the flow-by head and pressing the material onto the core face with a spatula. The head is replaced and confinement and pore pressure reapplied. Methane gas can be injected through the injection port and through the core for permeability measurements. Treatments to remove the material can either be washed by the core face through the flow-by head or can be injected through the damaging material and into the core matrix. Treatment effectiveness is evaluated by measuring the methane gas permeability following the treatment.

3. 2,500 psi confining pressure, 1,500 psi pore (back pressure) and a temperature of $100{ }^{\circ} \mathrm{F}$ was maintained to ensure that $\mathrm{CO}_{2}$ exists in the supercritical phase.

4. Core flooding was in one direction to model field injection. $2 \% \mathrm{KCl}$ was used to establish single phase permeability, initially. This was done in view that treatments, other than those designed to utilize $\mathrm{CO}_{2}$ boost, cannot rely on production from the reservoir to aid recovery, and that the treatment must be capable of removing damage to gain back injectivity into the reservoir. Also, if retained permeability measurements were made by flow in the

"Treatment of Hydrocarbon, Organic Residue and Production Chemical Damage Mechanisms Through the Application of Carbon Dioxide in Natural Gas Storage Wells” 
Figure 1 - Flow-By Open Face Core Holder Used in Flow Studies

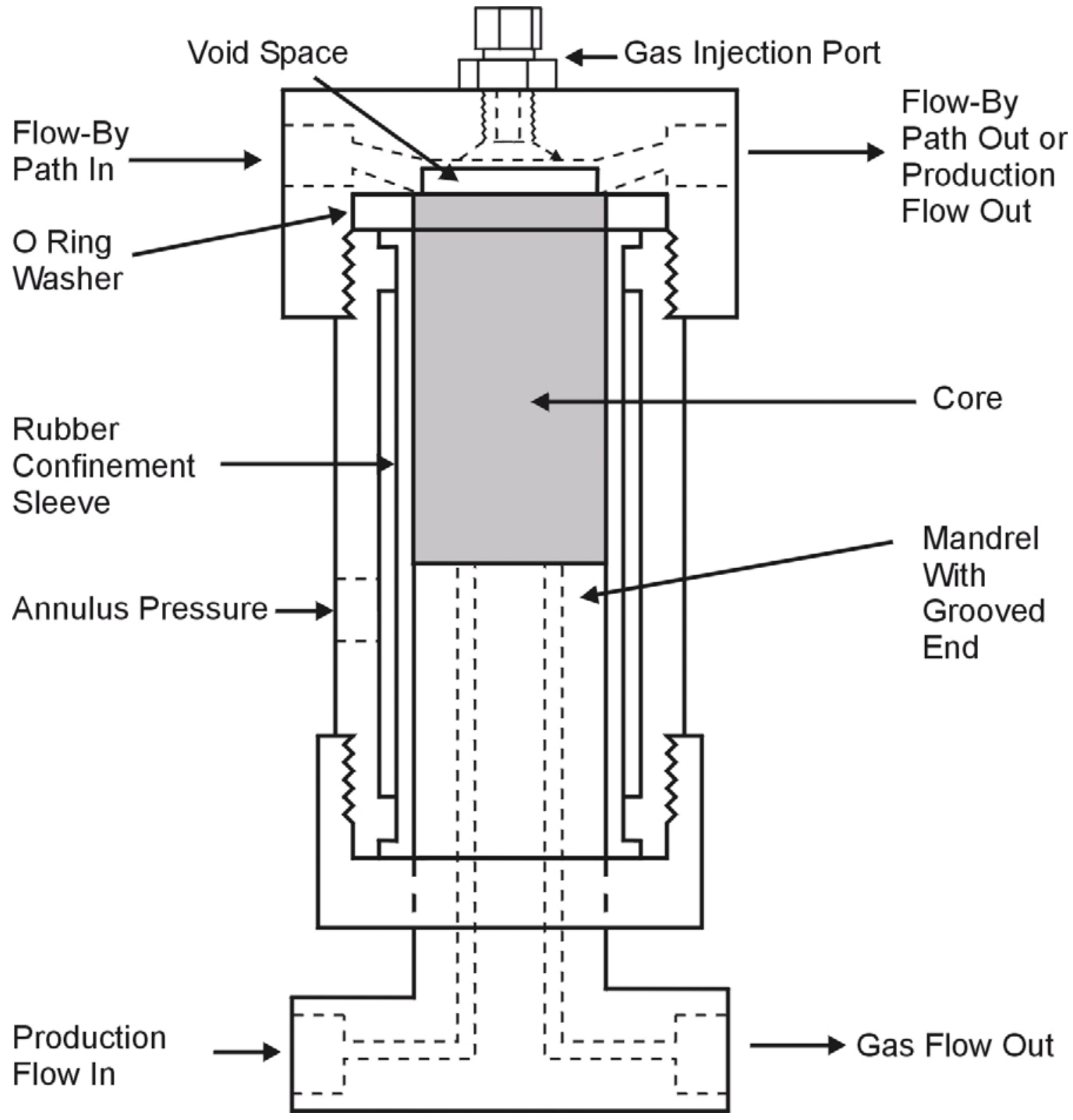

"Treatment of Hydrocarbon, Organic Residue and Production Chemical Damage Mechanisms Through the Application of Carbon Dioxide in Natural Gas Storage Wells” 
"production" direction, the effectiveness of the treatment could be confused by the simple lift-off of the damaging material with production flow.

Figure 2 depicts the flow diagram for the conducted flow studies. A multiple valve arrangement allows for flow in both directions with any of the fluids, either methane gas, brine or treatment fluids. A back pressure regulator allows control of the system pressure. This is particularly important when applying liquid or supercritical $\mathrm{CO}_{2} . \quad \mathrm{CO}_{2}$ is loaded into the displacement reservoir from eductor tube gas cylinder. A bi-directional differential pressure transducer monitors pressure drop across the core plug during flow. Pump rates, temperatures and pressures are recorded continuously by a data acquisition system not shown. Cell heaters are also not shown in the diagram.

5. The sample is core flooded with methane gas to residual water saturation.

6. Damaging material is pressed on the core.

7. The sample is flooded again with methane gas to measure retained permeability following damage. In the case of tests with bailed materials, gas is flowed for five days to age the material and core flooded again with methane gas to measure retained permeability following ageing.

8. Treatment of the sample is conducted by flowing by the core face $30 \mathrm{ml}$ to purge flow system then injecting $100 \mathrm{ml}$ of supercritical $\mathrm{CO}_{2}$.

9. Finally, the sample is flooded again with methane gas to measure retained permeability following treatment. If damage still present, core is treated with 100 $\mathrm{ml}$ of $5 \% \mathrm{HCl}$ acid with iron control additives to remove any of the solids that may remain. A final flood with methane is conducted to determine effectiveness of acid treatment.

\section{Laboratory Flow Studies- Fractured Sample}

1. The test sample is prepared by fracturing the whole core sample and coring a one inch diameter core parallel to fracture (Figure 3). Previous experience in a recent Gas Research Institute funded study by StimLab gained experience in preparing fractured core for flow study ${ }^{6}$.

2. The fracture is then propped with scattered grains of 100-120 mesh sand to give a propped fracture width of about 125-150 micrometers.

3. The sample is then loaded in core holder with hollow spacers to insure unrestricted flow to fracture.

4. $\quad 1,000$ psi confining stress and 500 psi pore pressure are applied to yield a net 500 psi overburden pressure on fracture.

5. The test temperature is maintained at $80^{\circ} \mathrm{F}$.

6. Shut-in core overnight to allow fracture settling.

7. Flood the core with methane to obtain reference apparent permeability of fracture.

8. $\quad$ Flood fracture with asphaltic sludge to damage.

9. The sample is flooded with methane gas to measure amount of apparent permeability damage within the fracture and to dry the asphaltene in place.

10. The sample is treated with fluids to remove the sludge and soaked if needed. For $\mathrm{CO}_{2}$ treatments the pore pressure of the system was increased to 1,000 psi to

"Treatment of Hydrocarbon, Organic Residue and Production Chemical Damage Mechanisms Through the Application of Carbon Dioxide in Natural Gas Storage Wells” 
Figure 2 - Flow Diagram

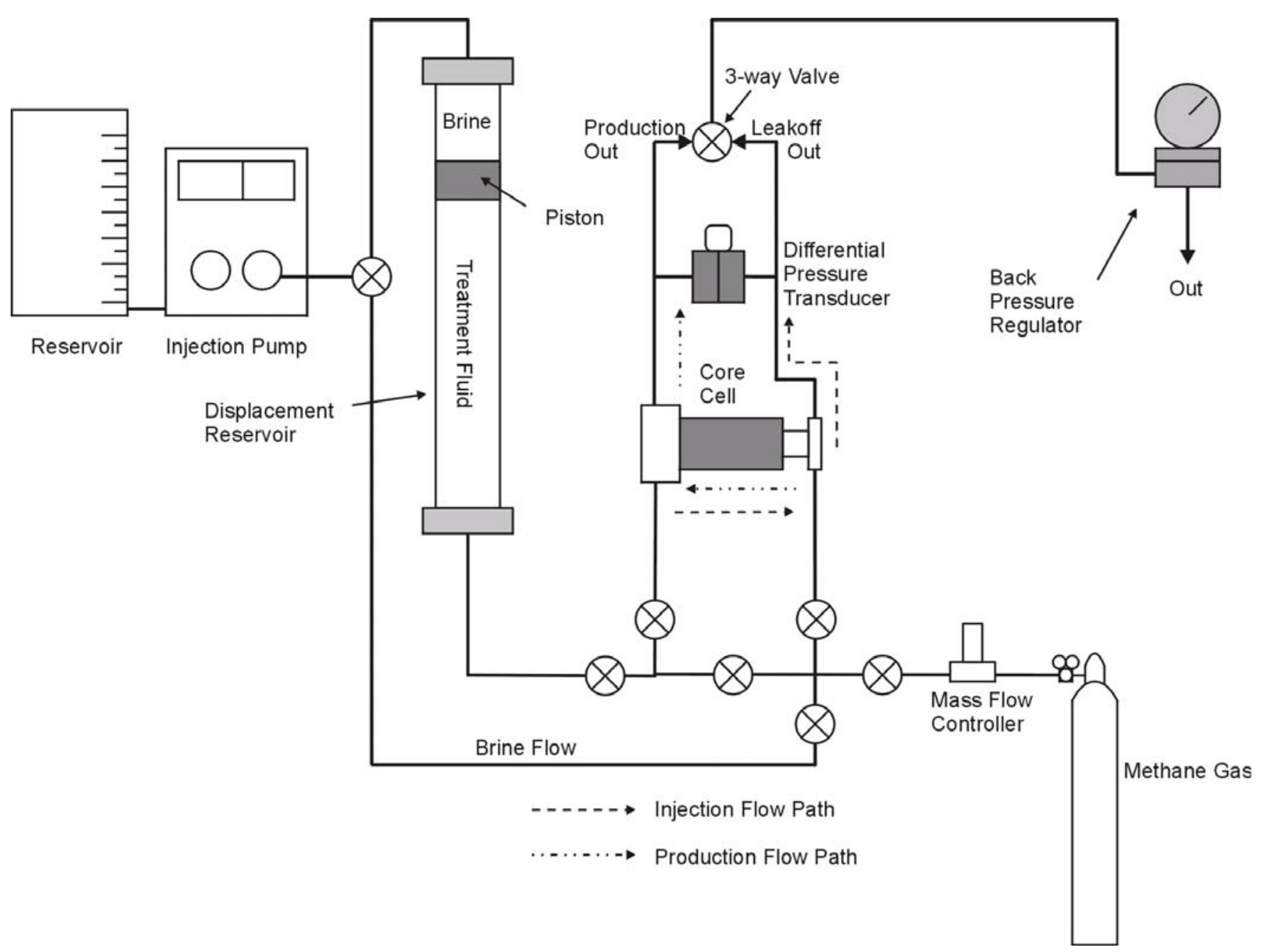

"Treatment of Hydrocarbon, Organic Residue and Production Chemical Damage Mechanisms Through the Application of Carbon Dioxide in Natural Gas Storage Wells” 
Figure 3 - Preparation of Fractured Overisel Core Sample

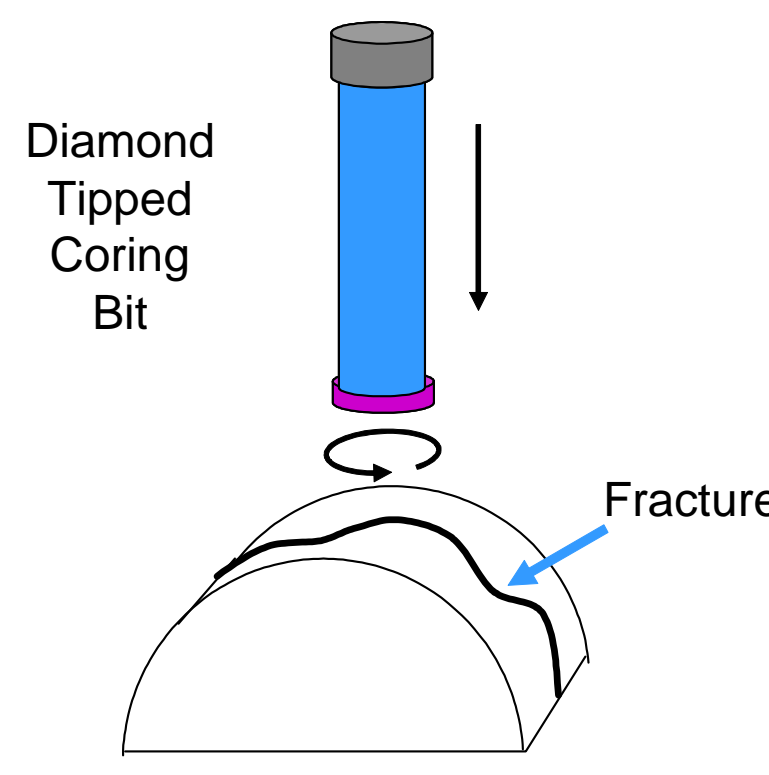

Section of Slabbed Whole Core Fractured With Wide Chisel

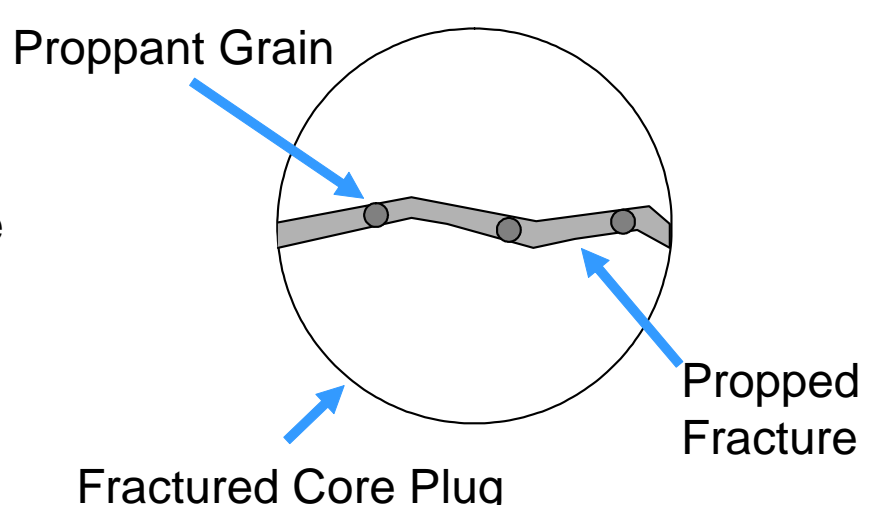

Prepped Core Plug Ready For Core Holder (End View)

"Treatment of Hydrocarbon, Organic Residue and Production Chemical Damage Mechanisms Through the 
maintain the $\mathrm{CO}_{2}$ in the super critical state during treatment application. The pressure was reduced back to 500 psi following the treatment and before methane flow to flash the $\mathrm{CO}_{2}$, which hopefully dislodged the hardened asphaltene material.

11. Measure effect of remedial treatment by flooding again with methane gas and determining permeability.

\section{Results and Discussion}

The results of the laboratory program demonstrate that $\mathrm{CO}_{2}$ can be successful in removing some types of damage caused by hydrocarbons, organics and production chemicals. At Huntsman Field, damage that was caused by native crude oil, valve grease and compressor oil was effectively removed by injection of pure, super-critical $\mathrm{CO}_{2}$. However, not all damage of this type can be addressed as suggested by the inability of $\mathrm{CO}_{2}$ and several other commercial production chemicals to remove asphaltine-based damage from Overisel core plugs.

The results of the laboratory program have directly supported one of the critical premises of the project, that $\mathrm{CO}_{2}$ may be effective in removing hydrocarbon-based damage in gas storage wells.

\section{Sample Analysis}

Samples from Huntsman field were initially grouped into three classifications represented by samples 10, 21 and 23. These were analyzed first, but volatile components and moisture were not included in those analyses. Kinder-Morgan later requested that the remaining samples 10, 21 and 23 be returned to them for more in-depth analysis. Therefore, these were not available for further analysis to obtain moisture and/or volatile content. Table 1 depicts the samples taken and analyzed from the Huntsman storage field.

\section{Table 1 - Bailed Samples from the Huntsman Storage Field}

\begin{tabular}{ccll}
$\begin{array}{c}\text { Recovered } \\
\text { From Well }\end{array}$ & $\begin{array}{c}\text { Approximate } \\
\text { Amount }(\mathrm{g})\end{array}$ & Descirpiton & Analyzed \\
\hline 2 & 111 & Quartz sand, possible frac sand with some formation material & \\
3 & 20.3 & Black soft oily solid in granules & $\sqrt{ }$ \\
7 & 27 & Brown dry powder with some scale fragments and clay & $\sqrt{ }$ \\
8 & 39 & Black slightly moist soft solid, some Teflon tape & $\sqrt{ }$ \\
10 & 125 & Dark gray to black semisolid oily clumps & $\sqrt{ }$ \\
21 & 40 & Dark gray powder with clumps, silica and scale visible & $\sqrt{ }$ \\
23 & $>200$ & Mostly quartz sand with some dark fragments, damp & $\sqrt{ }$ \\
28 & 2 & Dark black oily solid & \\
30 & $>200$ & Tan-black moist sludge & \\
31 & 10 & Dark brown moist sludge & $\sqrt{ }$ \\
43 & $>200$ & Redish brown dry powder and possible scale &
\end{tabular}


Each sample analysis result are given in four tables, content summary, classification, XRD identification of solids and XRD identification of xylene and $\mathrm{HCl}$ acid insoluble components. The percentages are by weight. The percentages reported in the classification are of the material remaining after the moisture or volatiles were removed. In content summary, hydrocarbon content is the xylene soluble component, moisture includes volatile hydrocarbons as well as water, salt is reported as percent sodium chloride, but may also contain other chloride salts. Scales are as identified by XRD analysis and include calcite, which can be a natural formation material. Formation materials include quartz, clays and other non-scale minerals. Quartz can be from sands used in hydraulic fracturing stimulation of the well that has flowed back into the wellbore.

The XRD analysis results show how the identified crystalline minerals were classified as either scale or formation material. This is based on XRD data from the reservoir rock characterization which identifies which minerals were present in the reservoir. Those not present are considered scales that have formed in the wellbore and near wellbore reservoir. XRD analysis of the insoluble solids content identifies those minerals that would be difficult to remove with conventional treatments such as xylene soaks or application of $\mathrm{HCl}$ acid. These tables are provided for each sample in Appendix A and notes of interest for some of the samples follow (by well).

Huntsman 10 - Sample 10 represents one of the initial 3 samples analyzed and the remaining sample returned to Kinder-Morgan. The Content summary excludes the moisture/volatile content of this sample and is only the solids component.

Huntsman 21 - Sample 21 represents one of the initial 3 samples analyzed and the remaining sample returned to Kinder-Morgan. The Content summary excludes the moisture/volatile content of this sample and is only the solids component.

Huntsman 23 - While many of the other samples showed high quartz content, it was visibly obvious from the uniformity and coarseness of the sand grains present in this sample, that the material was a sized quartz sand used for propping hydraulic fractures (frac sand). Sample 23 represents one of the initial 3 samples analyzed and the remaining sample returned to Kinder-Morgan. The Content summary excludes the moisture/volatile content of this sample and is only the solids component.

\section{Hydrocarbon Profiling}

Profiling of the hydrocarbon components was performed along with potential surface contaminants by chromatography. By comparing the profiles it was hoped that matches to suspected contaminants could be made and that the cause for the contamination could be pursued. Three materials were suspected to contribute to the hydrocarbon component of the bailed samples. These were native crude oil produced during the winter production

"Treatment of Hydrocarbon, Organic Residue and Production Chemical Damage Mechanisms Through the Application of Carbon Dioxide in Natural Gas Storage Wells” 
stage of the cycle, valve grease used in the routine maintenance of the wellhead and compressor oil from the gas compression facility. The following (Figures 4 through 6) show the profile of the three known hydrocarbons at the Huntsman Storage Field and that for several of the bailed samples extracted from the total sample with a standardized solvent.

Figure 4 depicts the hydrocarbon profile of the native crude at the Huntsman storage field. The $\mathrm{y}$-axis is peak intensity and $\mathrm{x}$-axis is the elution time. The native crude was a "fresh" sample brought to surface during a production stage and was not weathered, i.e. light ends included. Lighter hydrocarbons are on the left or first to elude from the column. Figures 5 and 6 depict the response to compressor oil and valve grease, respectively. Comparative results are made from Figure 7 for the following samples:

HS \#8 (Figure 7a) - The profile of hydrocarbon material bailed from well 8 appears to be a mixture of weathered crude and valve grease. Another "heavy hydrocarbon” peak is unidentified in this sample.

HS \#10 (Figure 7b) - The hydrocarbon profile for well 10 appears to be very similar to the native crude sample with some of the light ends evaporated or weathered. A small amount of compressor oil could also be present.

HS \#21 (Figure 7c) - Bailed material from well 21 contains a small amount of weathered crude, but mostly valve grease.

HS \#30 (Figure 7d) - The well 30 hydrocarbon fraction appears to be a mixture of weathered crude and compressor oil.

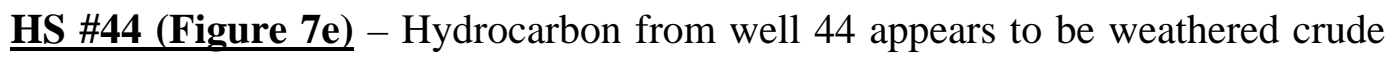
with most light ends removed.

\section{Laboratory Flow Studies}

Prior to the Huntsman flow studies, a detailed petropraphic work (Appendix B) was conducted to determine the properties of this reservoir rock. Permeability to air of 249 md, a helium porosity of $19.3 \%$, and a grain density of $2.59 \mathrm{~g} / \mathrm{cc}$ were determined. Further the sand was characterized as a fine-grained sublitharenite to quartzarenite containing $2 \%$ plagioclase and $2 \%$ total clay.

Four core flow studies were then performed with Huntsman core samples from storage well \#26 taken from an estimated depth of 4,861 feet. These studies evaluated the effect of combination treatments of super critical $\mathrm{CO}_{2}$ followed by $5 \%$ hydrochloric acid (if necessary) with retained permeability to gas measurements taken between treatments and after the treatments were completed. They were with a discussion of the referenced plot: 
Figure 4 - Hydrocarbon Profile of Native Crude, Huntsman Storage Field

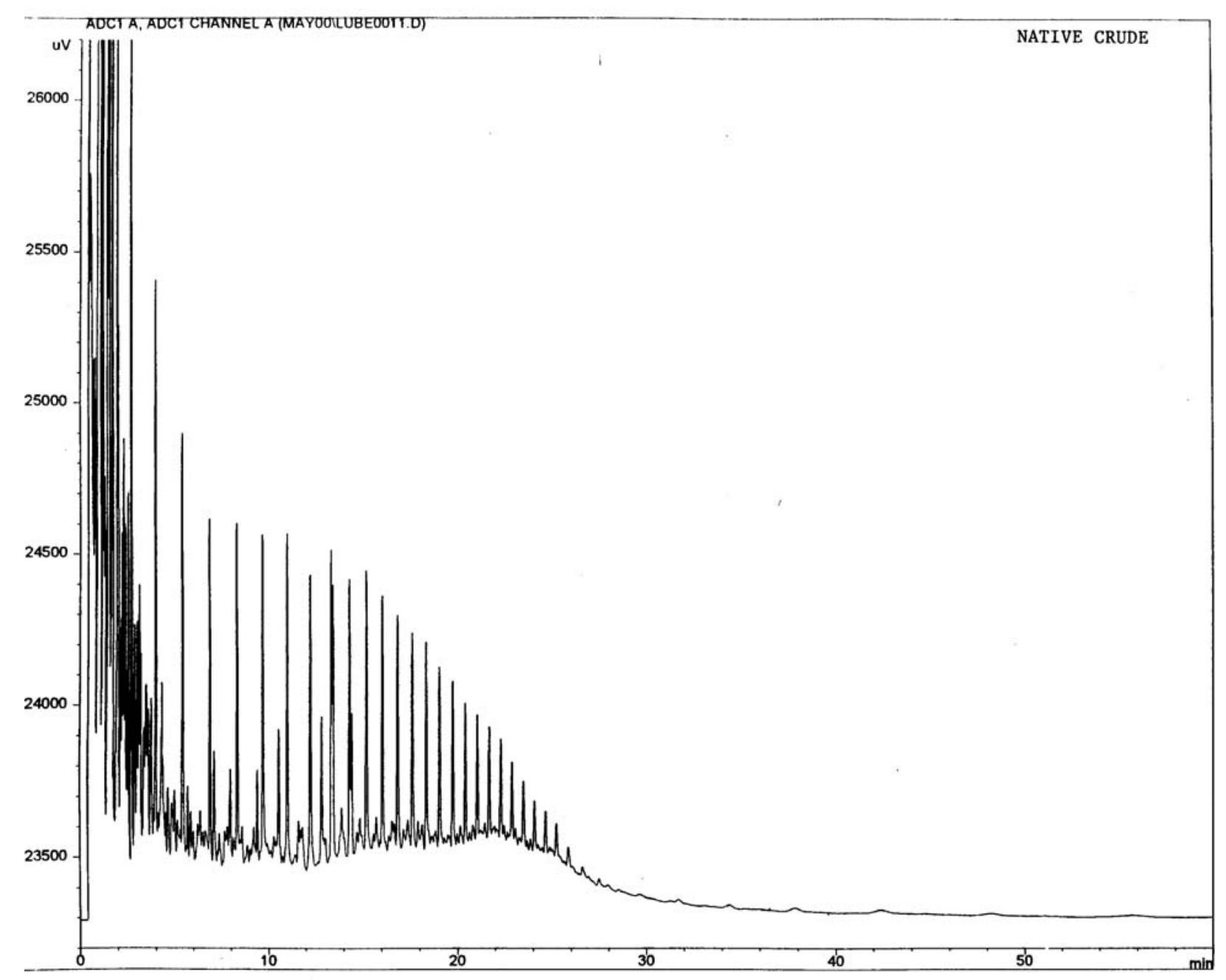

"Treatment of Hydrocarbon, Organic Residue and Production Chemical Damage Mechanisms Through the Application of Carbon Dioxide in Natural Gas Storage Wells” 
Figure 5 - Hydrocarbon Profile of Compressor Oil, Huntsman Storage Field

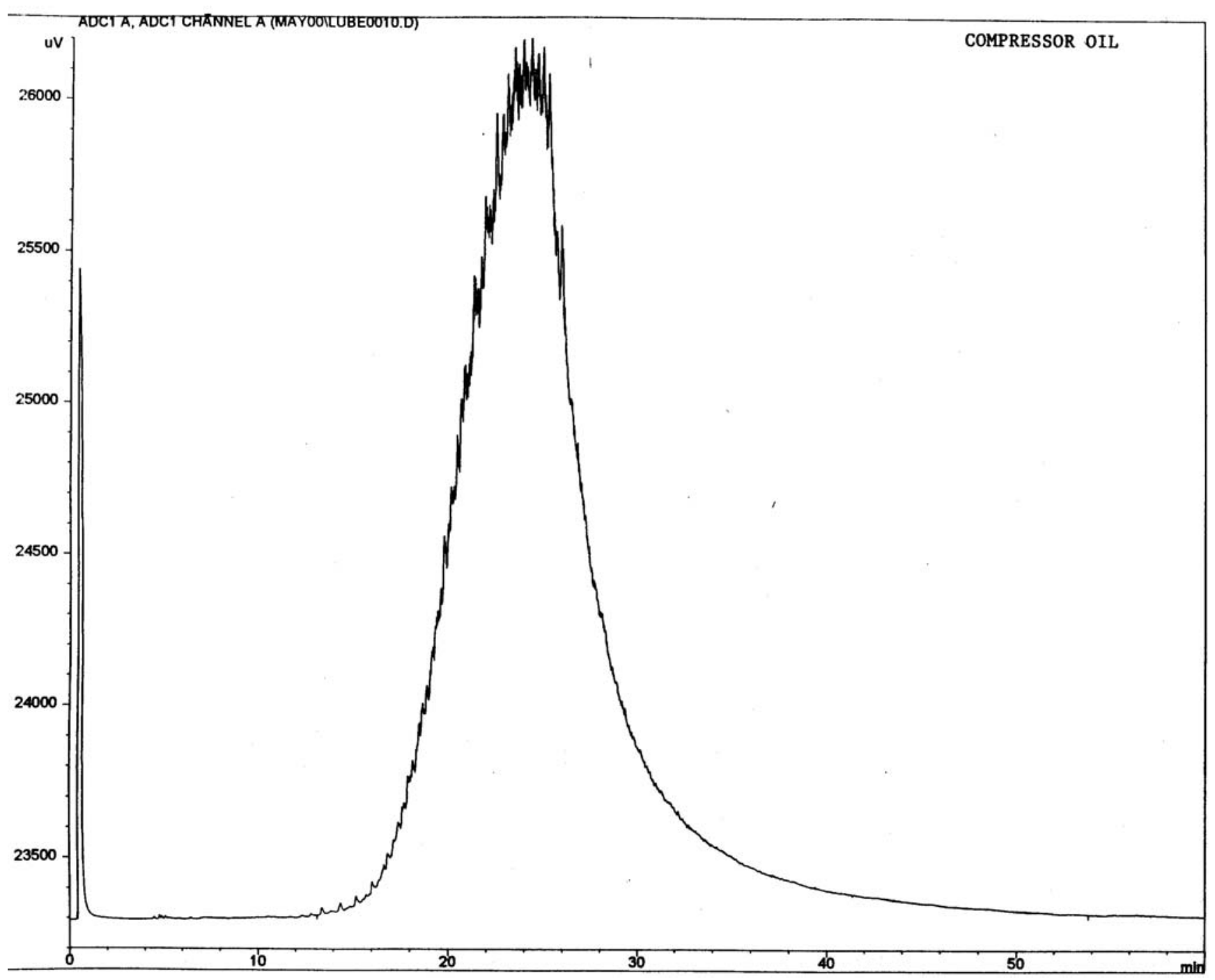

Final Report

DE-FC26-99FT-40702

"Treatment of Hydrocarbon, Organic Residue and Production Chemical Damage Mechanisms Through the Application of Carbon Dioxide in Natural Gas Storage Wells” 
Figure 6 - Hydrocarbon Profile of Valve Grease, Huntsman Storage Field

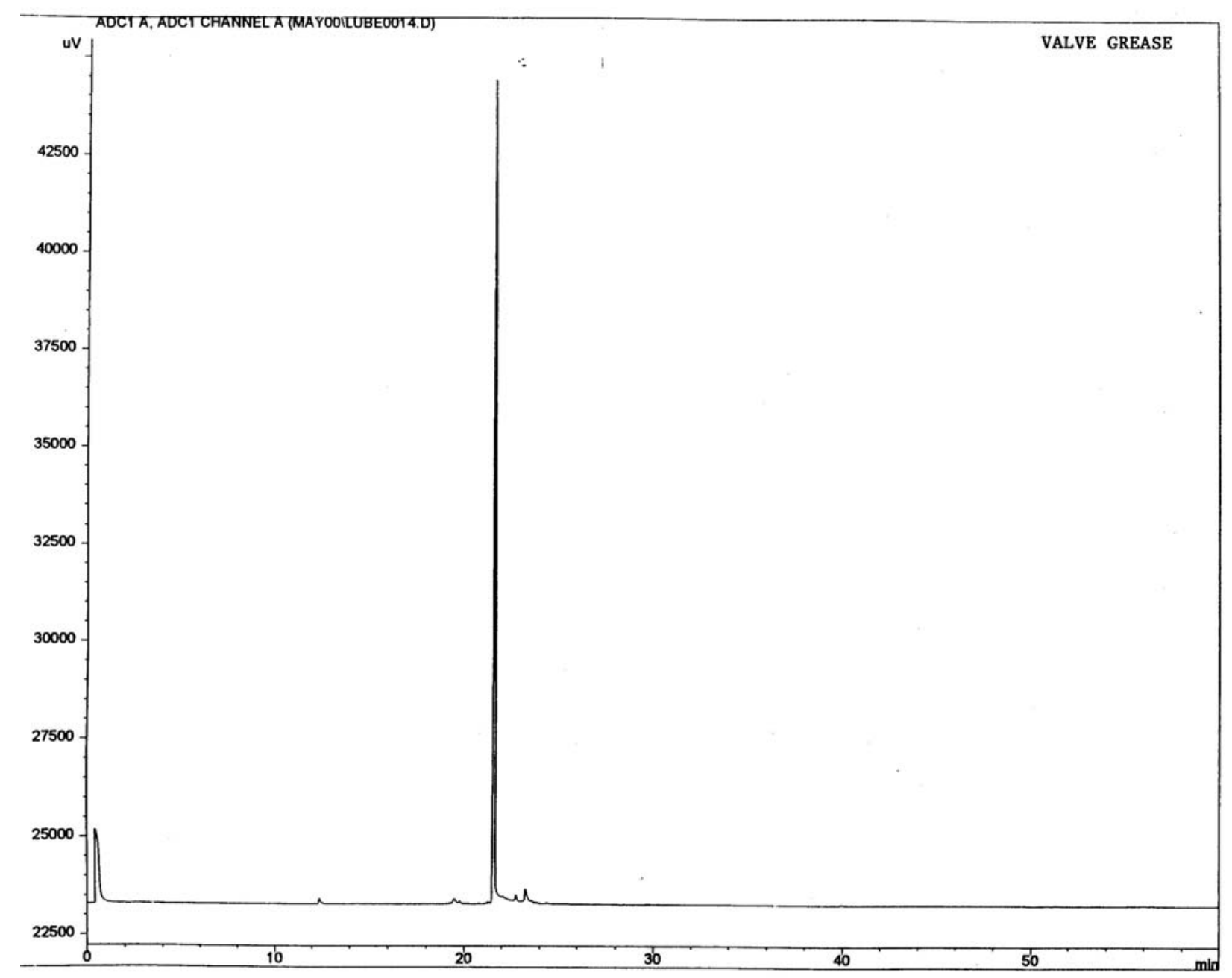

"Treatment of Hydrocarbon, Organic Residue and Production Chemical Damage Mechanisms Through the Application of Carbon Dioxide in Natural Gas Storage Wells” 
Figure 7 - Hydrocarbon Profiles for Huntsman Samples

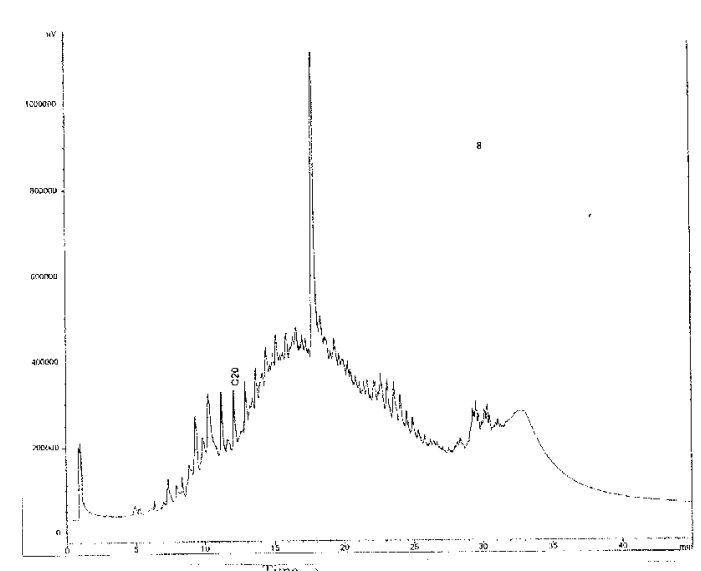

a) HS \#8

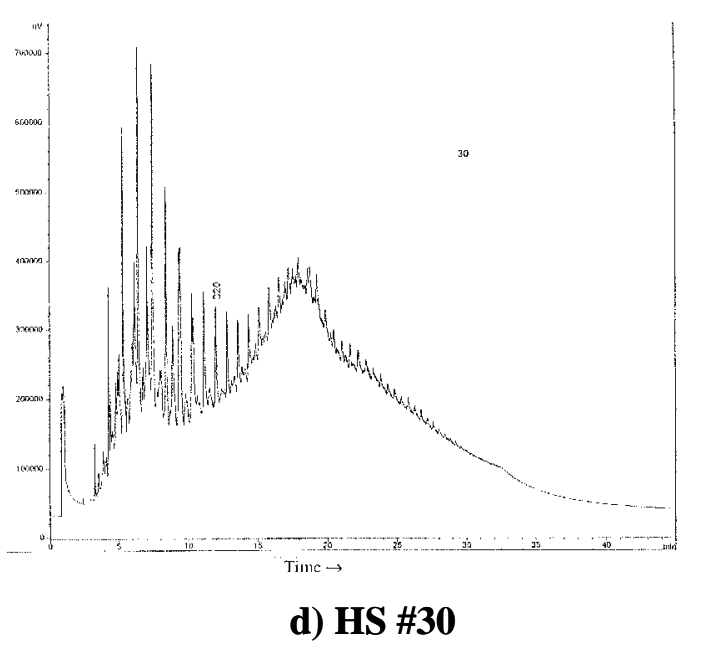

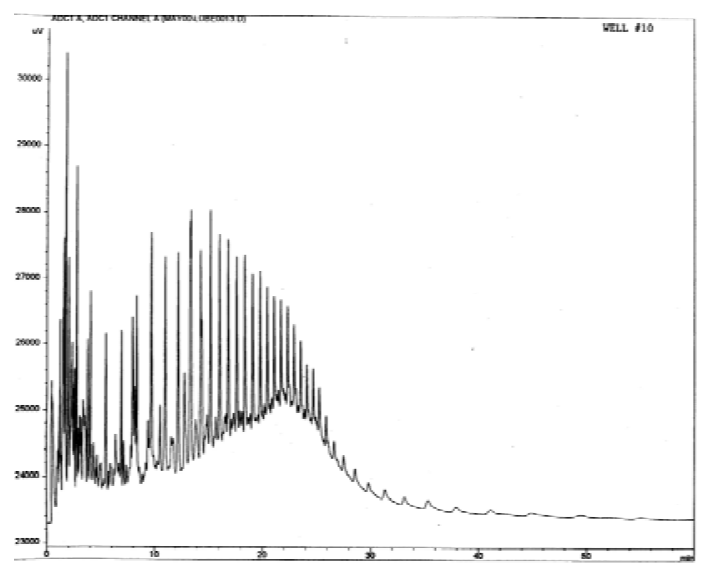

b) HS \#10

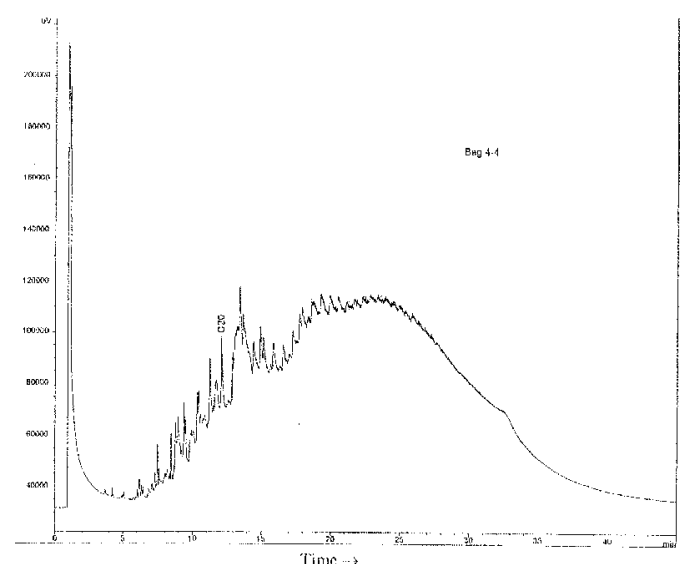

e) HS \#44

"Treatment of Hydrocarbon, Organic Residue and Production Chemical Damage Mechanisms Through the Application of Carbon Dioxide in Natural Gas Storage Wells” 
1. Methane permeability damage from valve grease and removal with super critical $\mathrm{CO}_{2}$ (Figure 8) - Flow study results show initial brine permeability near $170 \mathrm{md}$. Gas permeability improved with flow as the water saturation was reduced. At irreducible water saturation, the gas permeability measured $245 \mathrm{md}$.

After damaging the core face with the valve grease supplied by KinderMorgan, the retained methane permeability measured $33 \mathrm{md}$. The core was then flooded for five days with gas at a gas rate of $75 \mathrm{sccm}$ which is equivalent to about $1 \mathrm{scfm}$ per foot of zone for an 8 inch diameter wellbore. The gas permeability after the five days of flow measured 78 md as some of the valve grease and/or remaining water saturation evaporated or dried with the continued gas flow.

The core was treated with $100 \mathrm{ml}$ of super critical $\mathrm{CO}_{2}$ at a liquid flow rate of $5 \mathrm{ml} / \mathrm{min}$ for 20 minutes. This was followed by a retained gas permeability measurement. The post treatment measurement showed a 95\% permeability recovery.

Based on the permeability recovery obtained and limited core plugs available, it was decided not to treat the samples with the acid treatment, but to continue by damaging the core with the material from well 21 . Following the damage with the well 21 material, the methane permeability was reduced similar to that of the valve grease. Long term flow was not conducted, since this material should be aged already. Treatment was then conducted with the super critical $\mathrm{CO}_{2}$. The methane permeability was again recovered to $94 \%$ of the value before the second damage application and increasing when the test terminated.

2. Methane permeability damage from bailed sample from well \#10 and removal with super critical $\mathrm{CO}_{2}$ (Figure 9) - The hydrocarbon portion of the well 10 material appeared to be weathered native crude and possibly some compressor oil. With the success of the $\mathrm{CO}_{2}$ removal of the valve grease and well 21 material, it was decided to try the same treatment on a core damaged with material from well \#10. Figure 9 shows the initial permeability response with brine and methane gas (some early gas data was lost due to pressure transducer problems).

Following damage with the core material, the methane permeability was reduced to $64 \mathrm{md}$ or $18.3 \%$ of the original value. No ageing was performed as it was assumed the sample had already been aged in the well as indicated by the weathered state of the crude. Following treatment with $100 \mathrm{ml}$ of super critical $\mathrm{CO}_{2}$, the gas permeability showed a full recovery and some stimulation. The stimulation is most likely due to removal of some of the water saturation within the core by the $\mathrm{CO}_{2}$. This was not

"Treatment of Hydrocarbon, Organic Residue and Production Chemical Damage Mechanisms Through the Application of Carbon Dioxide in Natural Gas Storage Wells” 
Figure 8 - Damage Removal Core Flood Study, HS \#21

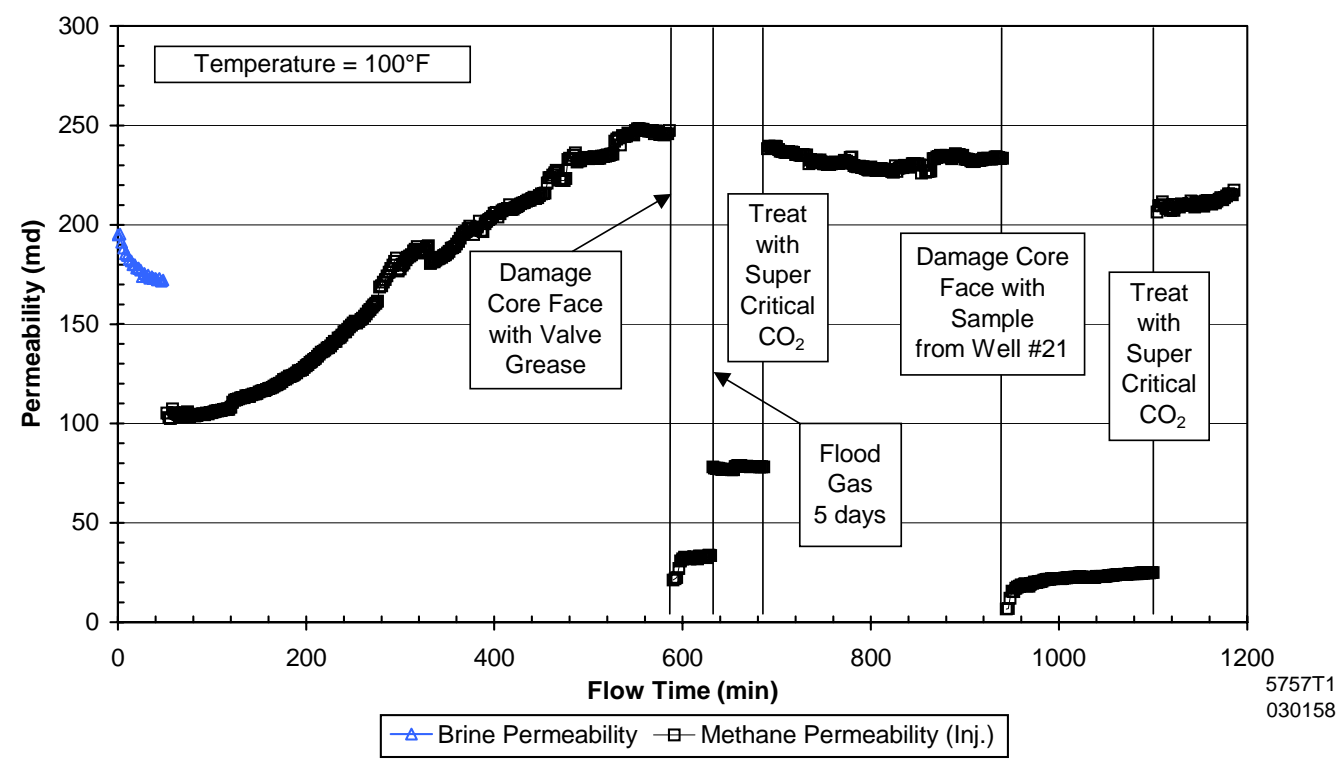

Figure 9 - Damage Removal Core Flood Study, HS \#10

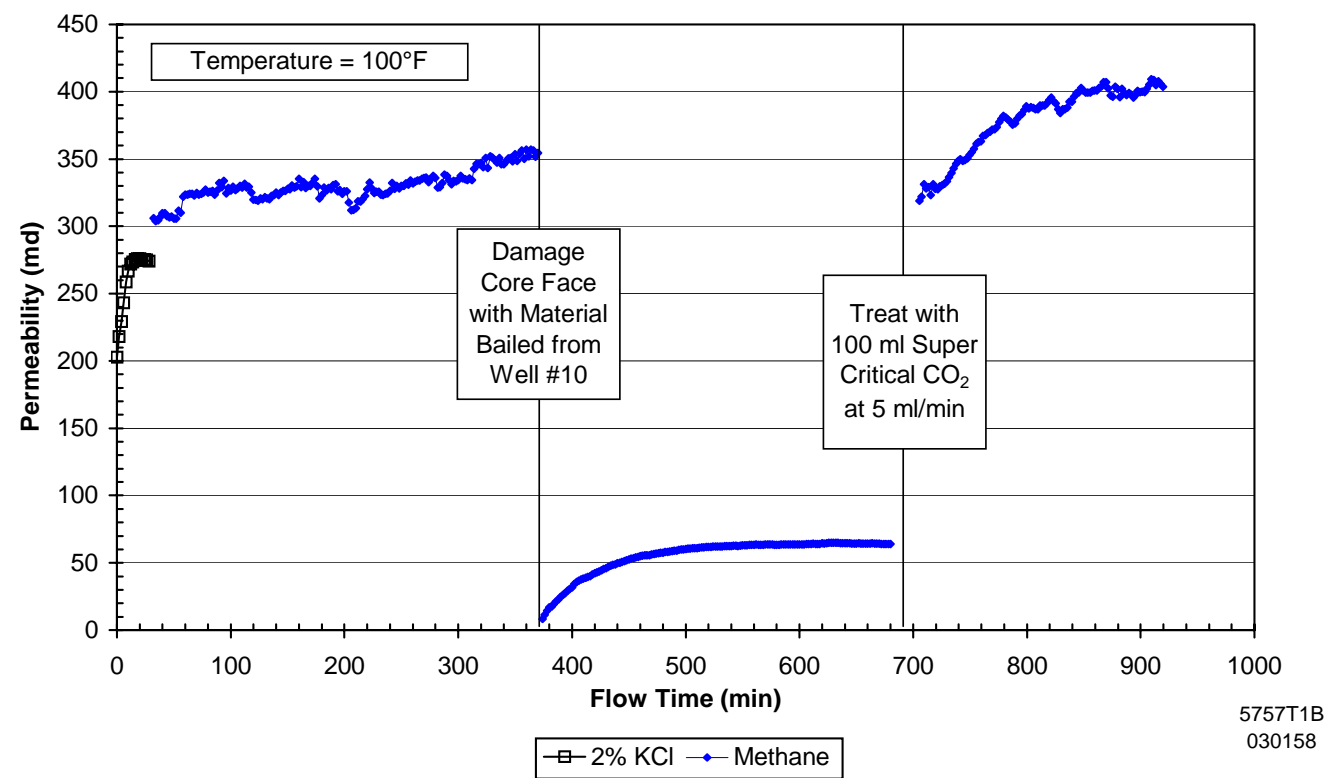

Final Report

DE-FC26-99FT-40702

"Treatment of Hydrocarbon, Organic Residue and Production Chemical Damage Mechanisms Through the Application of Carbon Dioxide in Natural Gas Storage Wells” 
observed in the first test as the five day gas flow most likely removed the excess water saturation prior to the $\mathrm{CO}_{2}$ treatment in that test.

3. Methane permeability damage from bailed sample from well \#30 and removal with super critical $\mathrm{CO}_{2}$ (Figure 10) - A core flood study was conducted to evaluate the ability of the liquid $\mathrm{CO}_{2}$ to remove weathered crude and compressor oil identified in the sample bailed from well 30 . The procedure was changed with this sample to determine the effect on both produced methane (flow out of the damage core face) and injection flow into the damaged core face. Figure 10 shows an initial brine permeability of $138 \mathrm{md}$. Produced methane at residual water saturation measured 42 md. Reverse flow with methane gave near the same value.

Once the core was damaged, the injected methane permeability was reduced to $4 \mathrm{md}$. Five day gas flow was conducted and the permeability increased only slightly as some of the liquid phase was removed allowing the permeability to increase to $5.5 \mathrm{md}$. Following an injection of liquid $\mathrm{CO}_{2}$ at 1,000 psi, both the injection and produced methane permeability were increase to greater than $100 \%$ retained permeability, indicating removal of the damage. The additional permeability gain is most likely from drying of some of the water saturation from the core.

4. Attempted damage to methane permeability with bailed sample from well \#44 (Figure 11) - A final flow test was to the damage potential of a drier bailed material containing mostly formation fines and weathered native crude. Since the material was dry it was mixed with a little toluene to form a paste that could be easily applied to the core face. The toluene should readily flash off once gas flow starts. Following application of the dried material, little change in the gas permeability was observed.

A second attempt was made to damage the core by mixing the bailed material with deionized water, which should form a thick paste with the clays present in the formation material. This paste was applied to the core face and the injection flow gas permeability evaluated again. However, no damage was measured. The core cell head was removed and the material coating the core face inspected. The material still coated the entire surface. It was therefore, concluded that the material from well 44 would not penetrate the formation matrix and create damage. It is apparently coarse enough in texture to offer little resistance to flow.

At the Overisel storage field, the objectives of the flow studies were to first characterize the formation core submitted for the A-2 carbonate zone. Next, using a supplied sludge sample taken from a pigging run, the study would attempt to damage the core sample with the material and dry in place with extended gas flow. Permeability measurements

"Treatment of Hydrocarbon, Organic Residue and Production Chemical Damage Mechanisms Through the Application of Carbon Dioxide in Natural Gas Storage Wells” 
Figure 10 - Damage Removal Core Flood Study, HS \#30

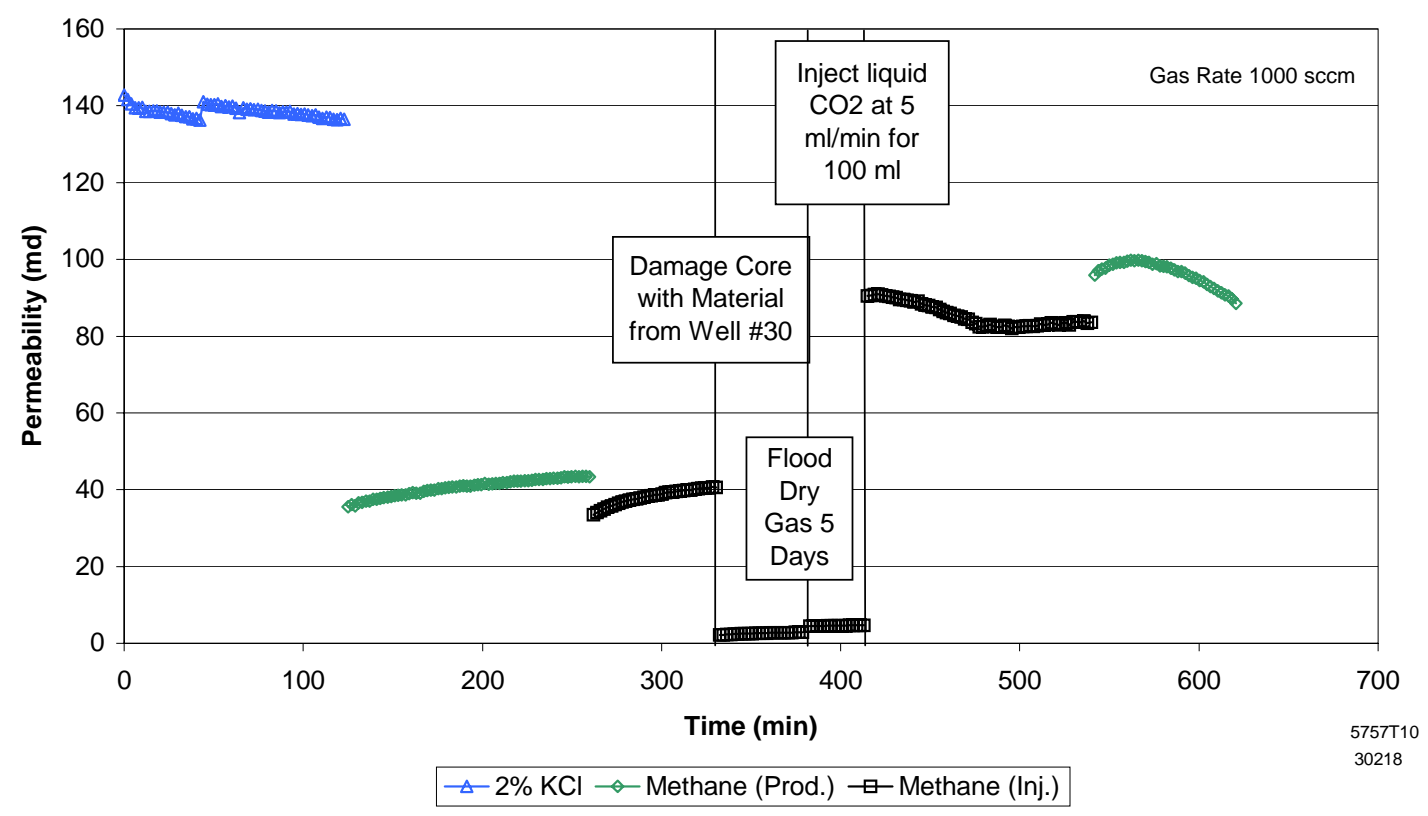

Figure 11 - Damage Removal Core Flood Study, HS \#44

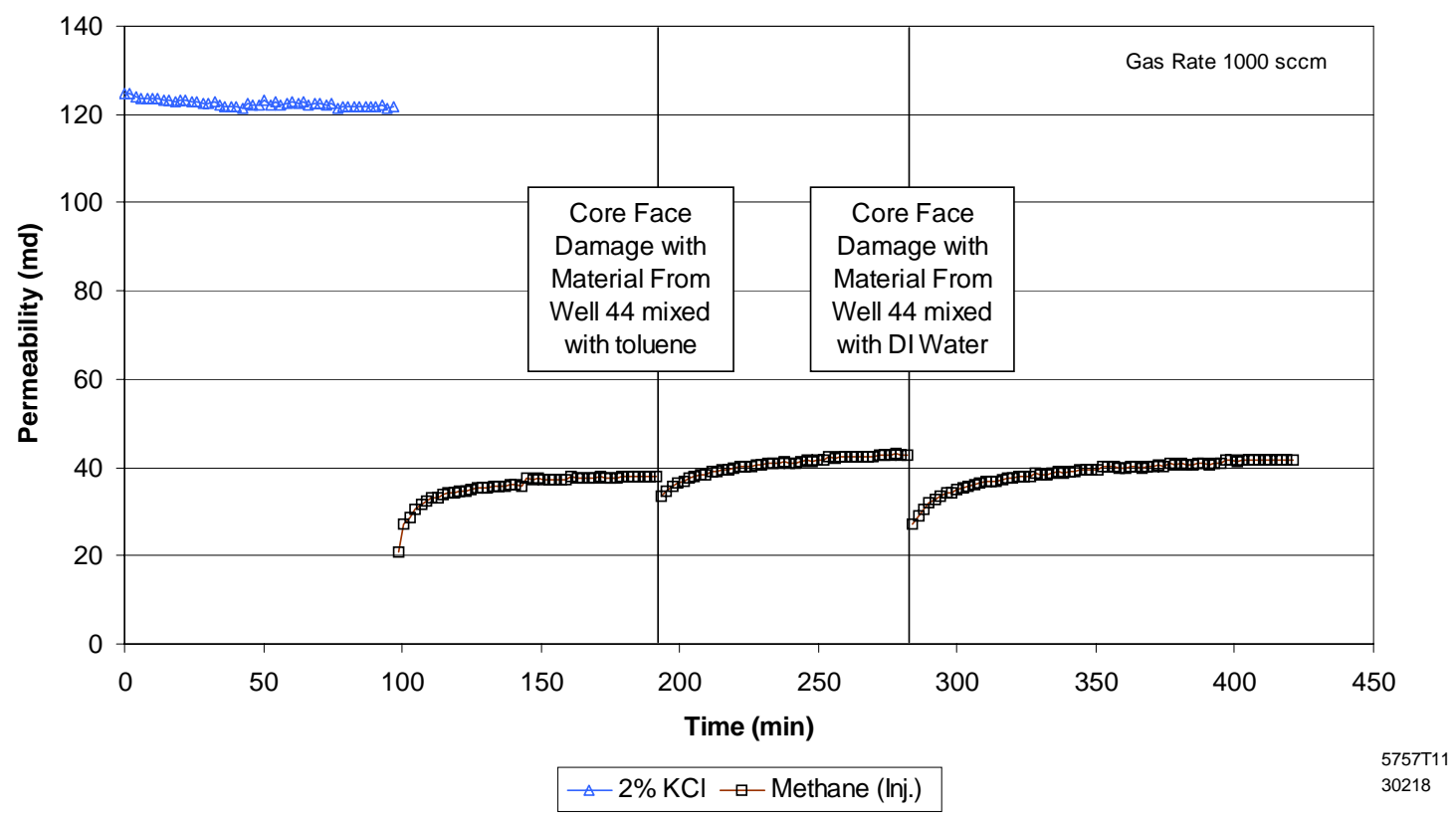

DE-FC26-99FT-40702

"Treatment of Hydrocarbon, Organic Residue and Production Chemical Damage Mechanisms Through the Application of Carbon Dioxide in Natural Gas Storage Wells" 
would be taken to measure the effect of damage and removal treatments. Treatments that were evaluated include straight solvents, liquid $\mathrm{CO}_{2}$, combination treatments with $\mathrm{CO}_{2}$ and miscible treatments of solvents in liquid $\mathrm{CO}_{2}$.

A detailed petropraphic work (Appendix C) was conducted to determine the properties of A-2 Carbonate sample. Permeability to air of $0.10 \mathrm{md}$, a helium porosity of $10.1 \%$, and a grain density of $2.825 \mathrm{~g} / \mathrm{cc}$ were determined. Further the sand was characterized as a crystalline dolostone (dolomite) with styolite (pressure solution seam) present. Because of the very low matrix permeability and presence of styolites, conductance into the reservoir is not through the matrix, but through natural fractures typical in dolomite reservoirs. So the fractured rock testing methodology was used.

Four core flow studies were performed with the representative sample of A-2 Carbonate core. These studies evaluated the effects of treatments of liquid $\mathrm{CO}_{2}$, alone, and in combination with various damage removal chemicals. Retained permeability to gas was measured between treatments and after the treatments. The flow tests were:

1. First Test of the Asphaltene Damaged A-2 Carbonate Cracked Core Flood (Figure 12) - The fractured and propped core sample was place in a core holder with flow-by head as discussed previously (Figures 1 and 2). Permeability to brine was measured in the plug, and since the matrix permeability is very low, this is mostly a measure of the fracture flow capacity.

Following an overnight shut-in of the test sample, another brine permeability measurement was made, which showed a considerable drop in permeability due to settling and proppant embedment. Relative gas permeability was then measured at several increasing flow rates. For displacement of a liquid phase the relative gas permeability should increase with increasing flow rate as shown.

For the first experimental attempt, the crude sample pigged from the surface flow line was mixed to uniformity and placed in a small displacement cylinder. The material was then pumped into the open core face for an estimate 10 crack (fracture) volumes. A return flow with methane showed the material was readily displaced out of the fracture with the gas flow. It was felt that the asphalt component was not concentrated enough and a large volume would be needed to deposit enough material. Since only a small sample $(<1$ liter) was available, it was centrifuged to concentrate the asphaltene. This concentrated material was then injected into the core with the intention of flowing until blockage occurred. However, this did not happen and steady pressure was obtained. A subsequent gas flow showed no damage. It was then felt that the fracture did not offer enough tortuosity to trap the asphaltene. A high permeability ceramic disc was added to the end of the fractured core plug

"Treatment of Hydrocarbon, Organic Residue and Production Chemical Damage Mechanisms Through the Application of Carbon Dioxide in Natural Gas Storage Wells” 


\section{Figure 12 - Results of Core Flood Study to Deposit Asphaltene in Cracked A-2 Carbonate Core, First Attempt}

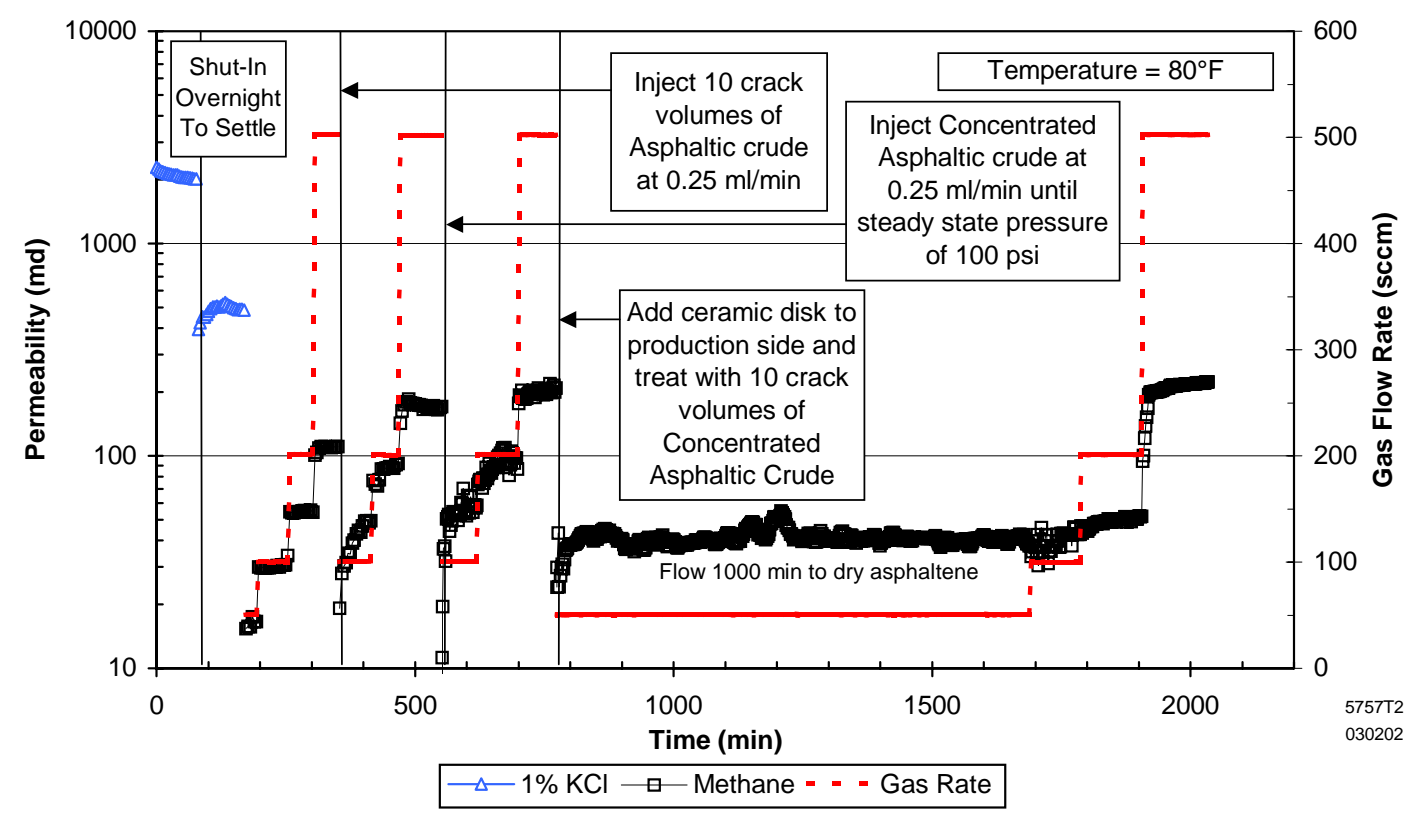

to filter out the asphaltene and fill the fracture. Ten crack volumes of the asphaltic material was injected followed by gas flow to dry the asphaltene in the fracture. However, when the gas rate was increased, no damage was observed.

2. Second Test of the Asphaltene Damaged A-2 Carbonate Cracked Core Flood (Figure 13) - Another cracked core sample prepared using a new sample of pigged material, was coated with a thick coating of semisolid asphaltene. Little or no methane permeability was expected as most flow should be through the core matrix. An indication of the success of the treatment would be a substantial increase in the gas permeability as the asphaltene is removed and the propped fracture is open to gas flow. The cubic law would predict a permeability of 7.5 Darcy for a smooth walled fracture. Roughness of the wall and the presence of the embedded proppant grains will introduce turbulence and the permeability should not be that great. An indication of the order of permeability to be expected is given in the brine permeability measurement made in the first test on the open and propped fracture. This was approximately 2 Darcy.

An initial permeability value was measured at $1.4 \mathrm{md}$. This is greater than the matrix permeability of the sample, indicating that some gas flow was occurring through the fracture. After injection of $100 \mathrm{ml}$ (400 crack volumes) of $\mathrm{CO}_{2}$, there was a slight drop in the methane permeability. 
Figure 13 - Results of Core Flood Study to Deposit Asphaltene in Cracked A-2

Carbonate Core, Second Attempt

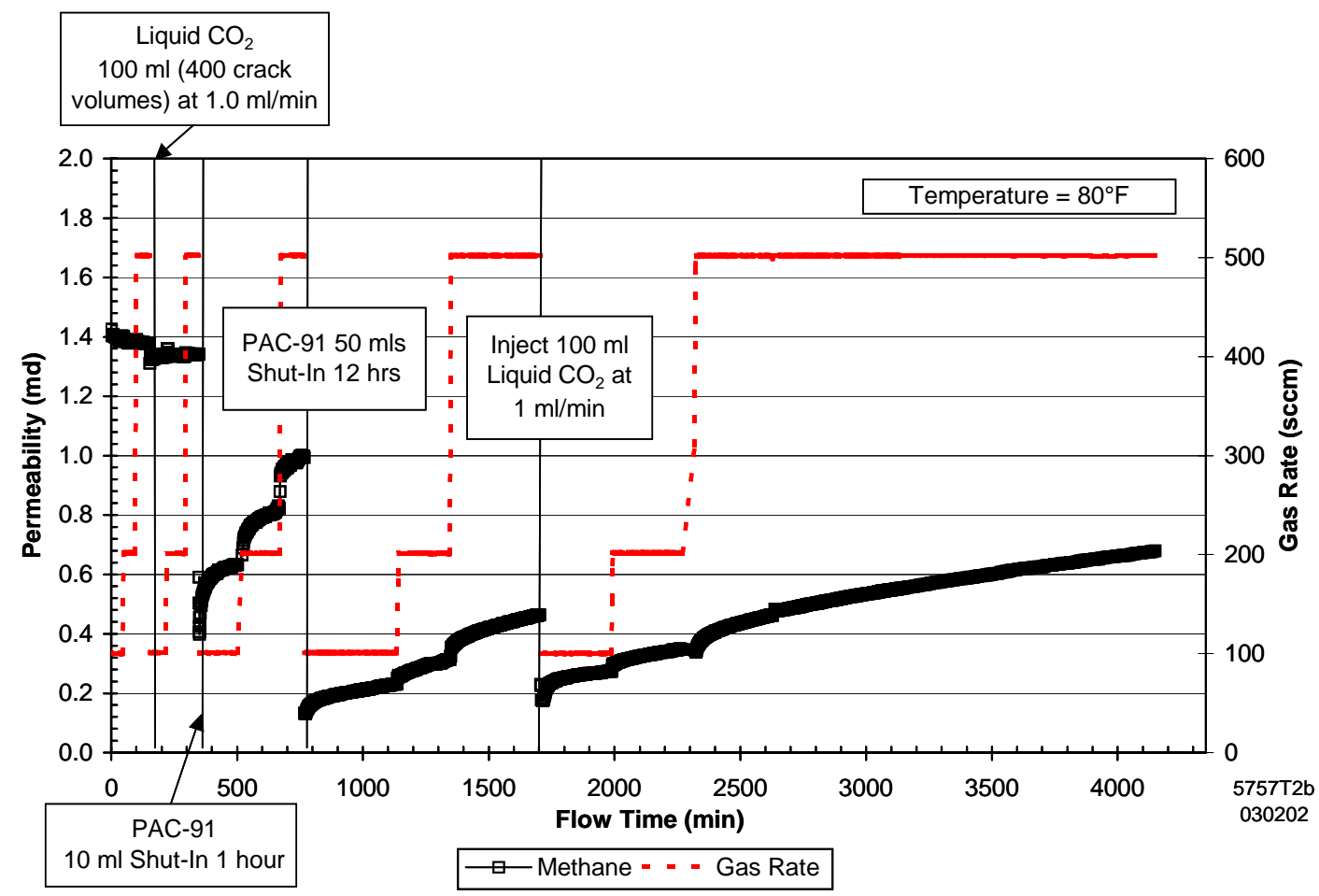

PAC-91 solvent was then injected and allowed to soak for one hour as recommended by the supplier. Following this the methane permeability was found to have been reduced. Increasing the gas flow rate pushed out some of the fluid saturation from the treatment and recovered some gas permeability, but no stimulation. The treatment volume was increased to $50 \mathrm{ml}$ and shut-in for 12 hours to soak. This resulted in another reduction in gas permeability. $\mathrm{CO}_{2}$ was again injected, this time at a lower rate to give more contact time. Again no stimulation was achieved as measured by a long term gas flow.

3. Third Test of the Asphaltene Damaged A-2 Carbonate Cracked Core Flood (Figure 14) - For this test, the core was again treated with PAC-91 and allowed to soak one hour with no improvement seen in the gas permeability. A combination treatment was performed injecting $100 \mathrm{ml}$ of $\mathrm{CO}_{2}$ followed by $10 \mathrm{ml}$ PAC-91, shut in 1 hour and then $100 \mathrm{ml}$ of $\mathrm{CO}_{2}$ flowed back in the production direction. This treatment simulates the application of a $\mathrm{CO}_{2}$ preflush followed by solvent treatment and then $\mathrm{CO}_{2}$ boost on recovery of the solvent and the wellbore materials. Unfortunately, the treatment was not effective and resulted only in a further reduction in methane permeability. 
Figure 14 - Attempt to Remove Asphaltene Damage with Pac-91 Solvent and Liquid CO2, Third Attempt

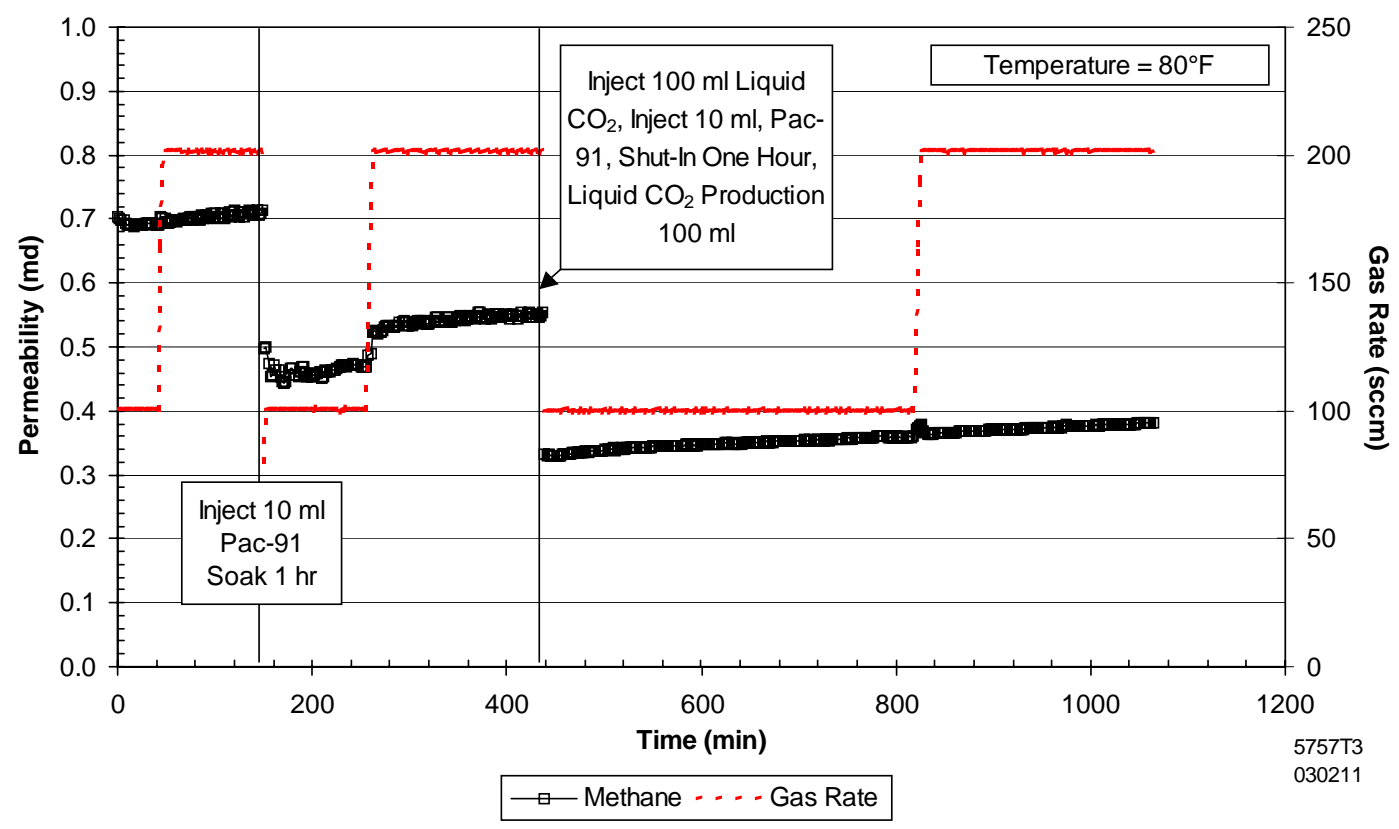

4. Fourth Test of the Asphaltene Damaged A-2 Carbonate Cracked Core Flood (Figure 15) -A similar flow study to the PAC-91 test was performed using the Cleartene 153 product. The supplier recommends the material be run from $10 \mathrm{gal} / 1000 \mathrm{gal}$ in brine up to $100 \%$. The treatment recommendation for difficult to remove deposits is to inject solvent, soak one hour, repeat 3 more times, and flow back. For this study the solvent was run without dilution.

The first stage treatment with soak stages had no effect and created gas relative permeability damage presumably by increasing the fluid saturation in the matrix permeability. A combination treatment was performed with $\mathrm{CO}_{2}$ as was done with the PAC-91 treatment, using a concluding with a $\mathrm{CO}_{2}$ flowback. Again, no improvement was observed. 
Figure 15 - Attempt to Remove Asphaltene Damage with Cleartene 153 Solvent and Liquid CO2

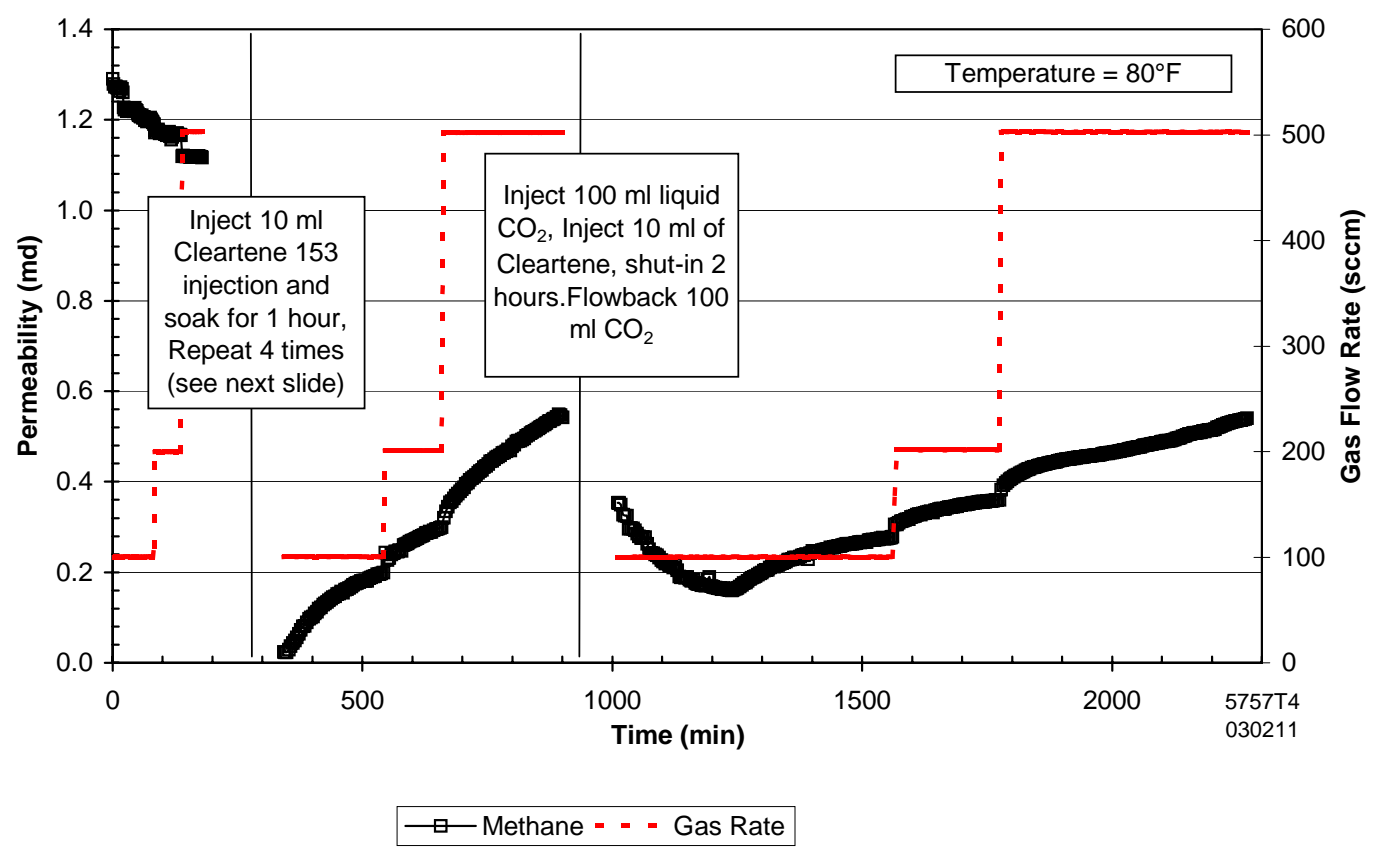

The plot of injection pressure for each of the four Cleartene solvent injection stages is shown in Figure 16. If the product was having success in removing the asphaltene from the fracture, the injection pressure should fall on subsequent treatment injections. The data shows the opposite with the pressure increasing until the differential pressure transducer pressure limit was reached. The increase is most likely due to continually increasing the fluid saturation in the matrix and in what ever flow paths are available.

Overall for the A-2 Carbonate flow tests, the data indicates that the treatments were not successful. Further, test four showed increasing pressure, suggesting that treatment is entering core matrix and not removing dried asphaltene material.

The assumption that minor flow paths are sufficient to contact the asphaltene in a plugged fracture and that the fracture is mostly plugged is most likely not correct. Otherwise, no injection into the well would be possible. Therefore, it must be assumed that some gaps in the asphaltene plugging exist as produced gas maintains some flow pathways. Therefore, the manner in which fractures are modeled was altered in order to create a 


\section{Figure 16 -Pressure Response During Repetitive Cleartene 153 Injections and Soaks}

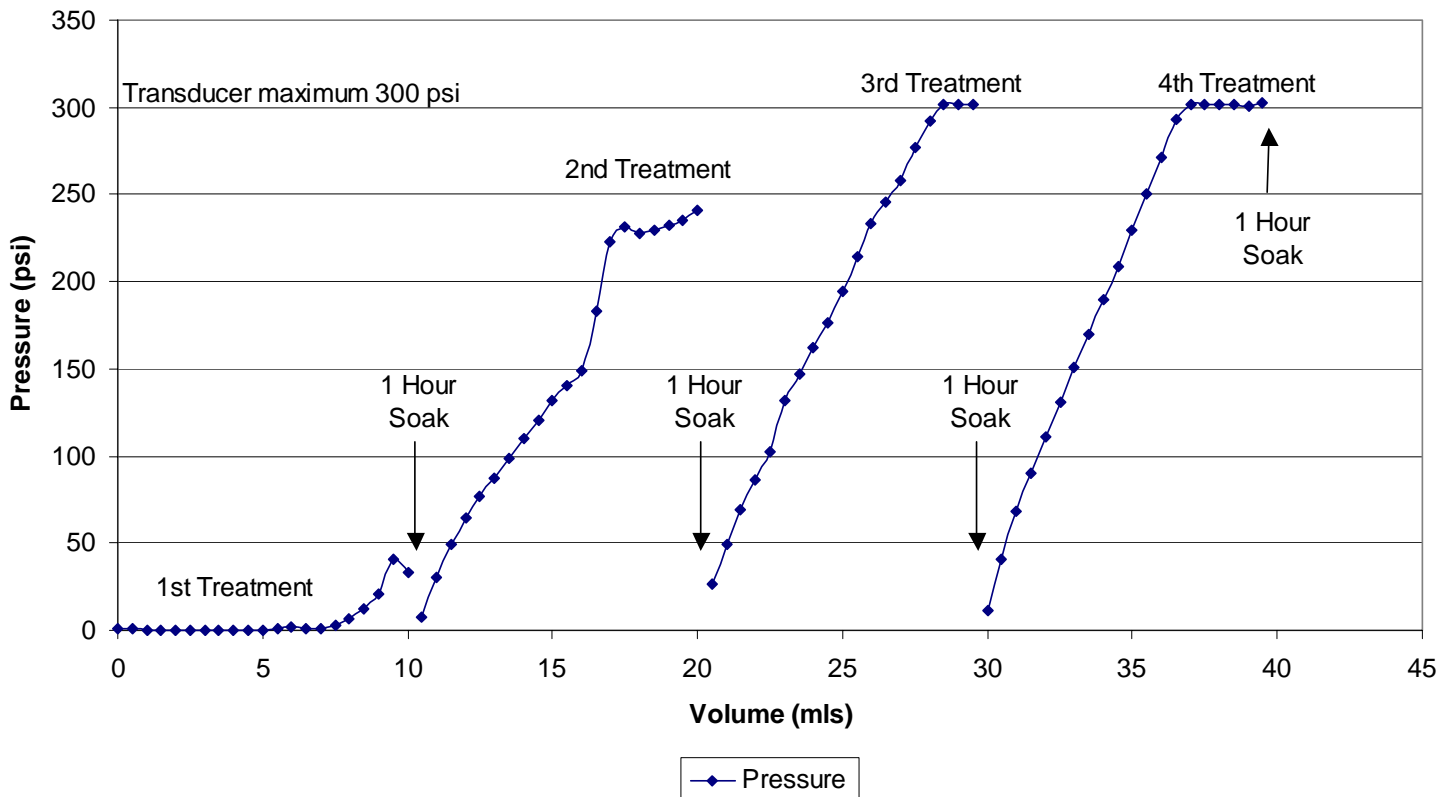

small pathway through the dried asphaltene deposit to offer more contact with the solvents and $\mathrm{CO}_{2}$.

This pathway was created by embedding a cord lengthwise in the asphaltene before drying and removing it after drying, as shown in Figure 17. This created a groove through the material that allows flow through the bed of dried asphaltene. Gas permeability will be greater with the groove, as compared to previous tests. However, removal of the apshaltene would be indicated by a much greater improvement in the measured permeability values. Four flow tests were repeated with the following results:

\section{Figure 17 - Preparation of Test Core With Groove}

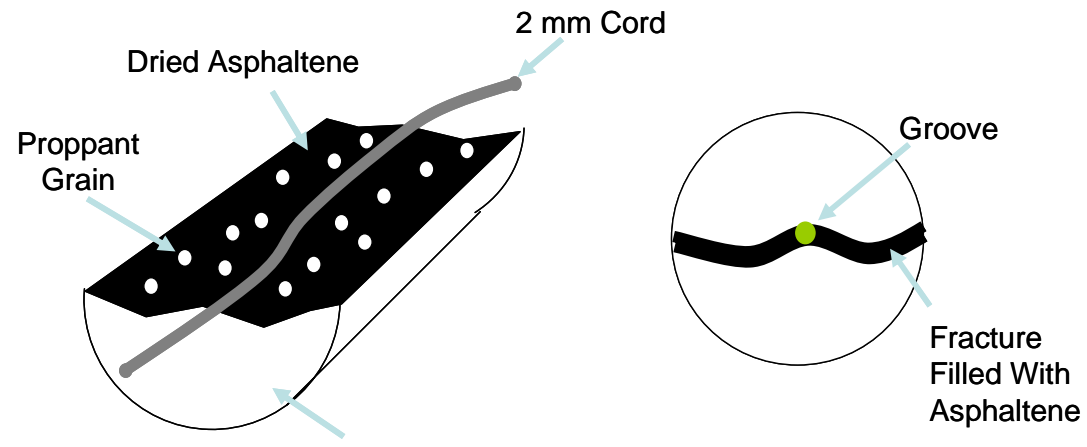

$1 / 2$ Fractured Core Plug

Prepped Core Plug During Drying

\section{Prepped Core Ready For} Core Holder

Final Report

DE-FC26-99FT-40702

"Treatment of Hydrocarbon, Organic Residue and Production Chemical Damage Mechanisms Through the Application of Carbon Dioxide in Natural Gas Storage Wells" 
1. Cleartene and $\mathbf{C O}_{2}$ (figure 18) - The treatment procedure was altered in the next test to form a miscible (the extent of miscibility was not determined in these studies) or comingled combination of the Cleartene solvent at 1 part to 9 parts liquid $\mathrm{CO}_{2}$. The combination treatment was applied at $1 \mathrm{ml} / \mathrm{min}$ for $30 \mathrm{~min}$ then shut-in one hour. This was repeated four times and the pressure dropped to flash the $\mathrm{CO}_{2}$. This treatment resulted in no improvement in the gas permeability. The treatment was repeated again at a higher rate of $10 \mathrm{ml} / \mathrm{min}$ for $200 \mathrm{ml}$ with a one hour shut-in. Again, no improvement was seen.

\section{Figure 18 - Attempt to Remove Asphaltene from Grooved Fractured Core Mixture of Cleartene and $\mathrm{CO}_{2}$}

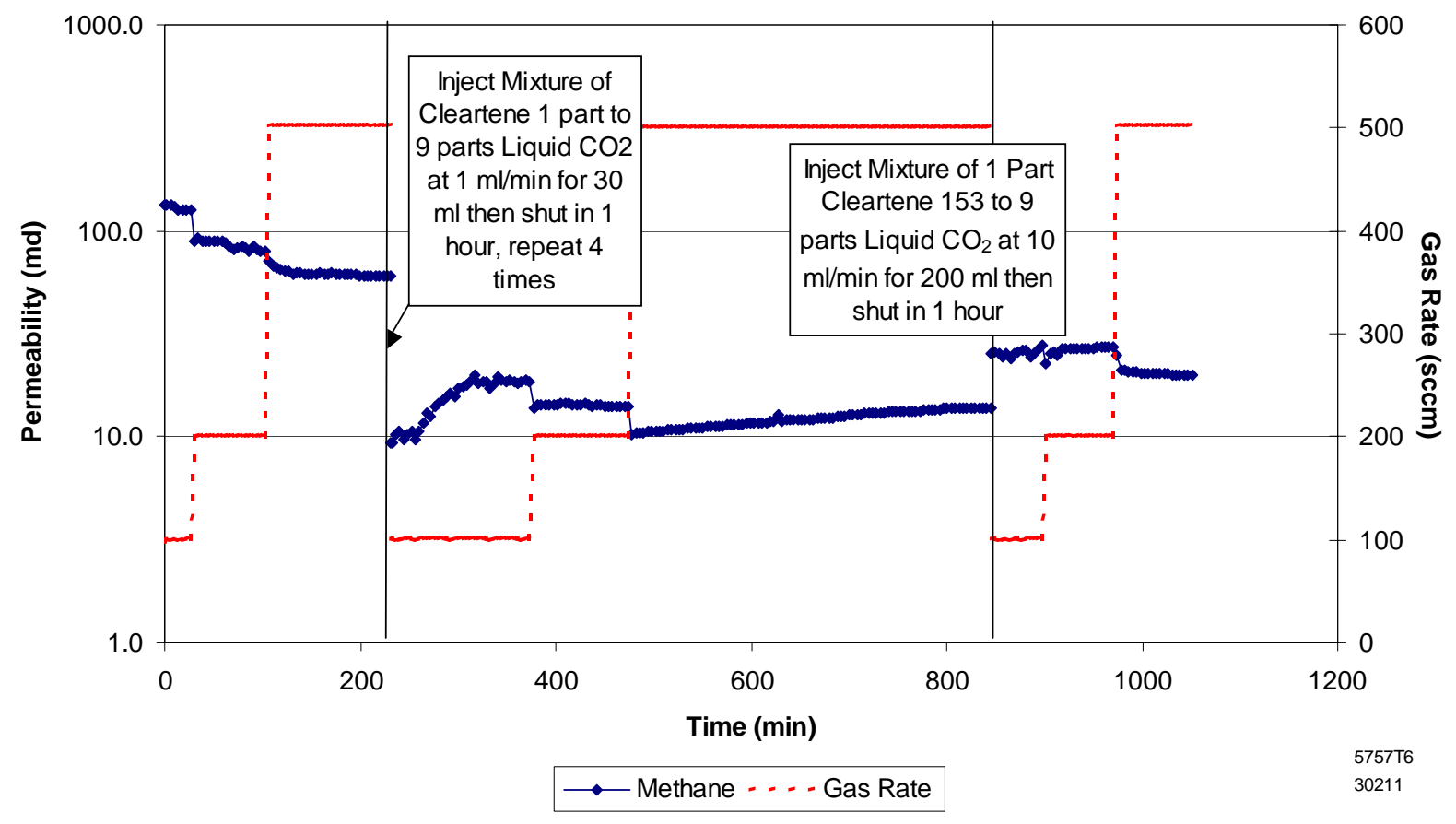

2. $\quad$ PAC-91 and $\mathrm{CO}_{2}$ (Figure 19) - The miscible treatment was attempted again with PAC-91 solvent at 1 part to 9 parts $\mathrm{CO}_{2}$. Both a low rate treatment with alternating soaks was performed along with a high rate treatment. Again no improvement was observed. 
Figure 19 - Attempt to Remove Asphaltene from Grooved Fractured Core Mixture of PAC-91 and $\mathrm{CO}_{2}$

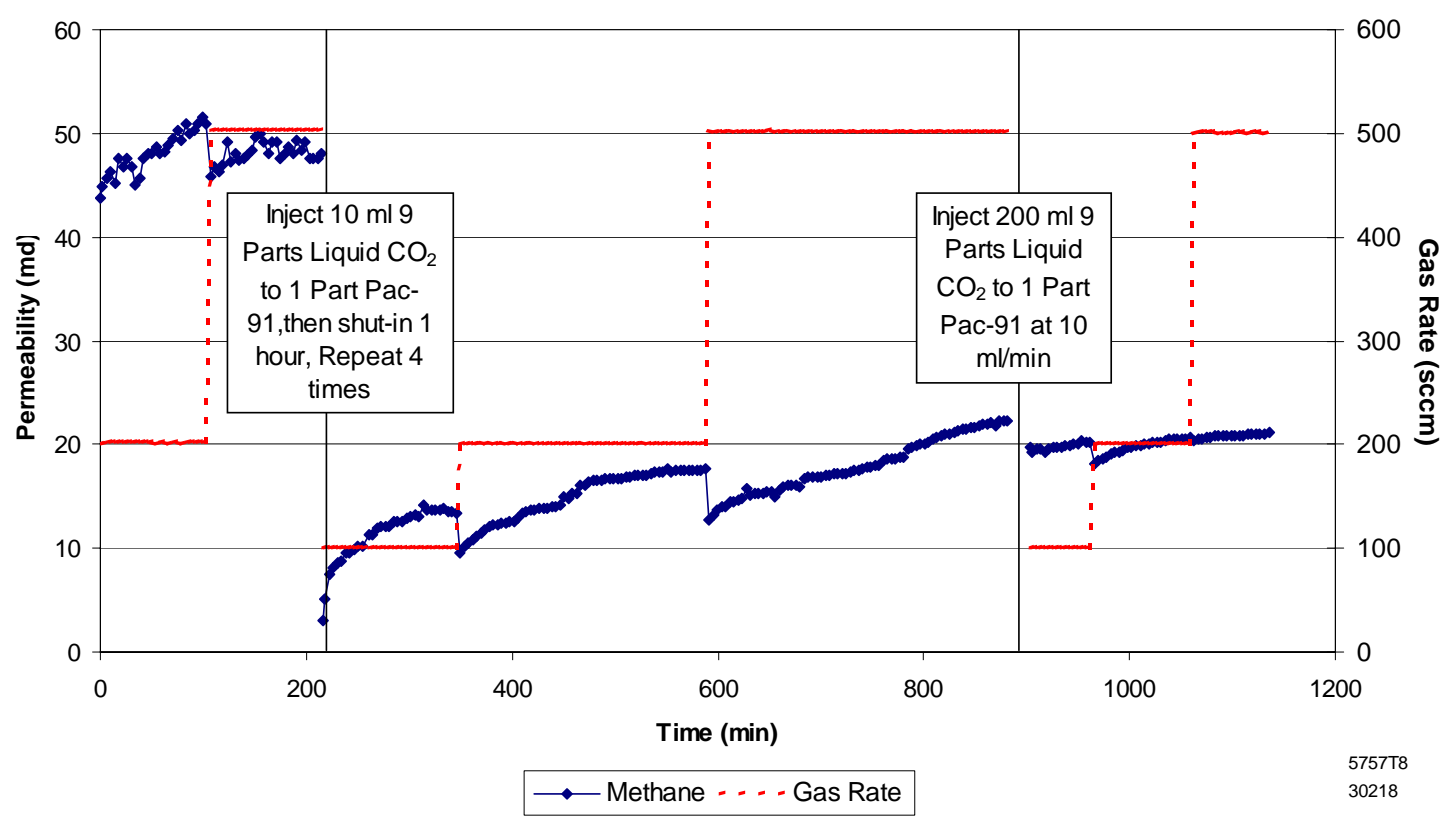

3. $\quad$ LS-489 and $\mathrm{CO}_{2}$ (Figure 20) - A third solvent sample was received at this stage of testing. LS-489 was applied as a miscible mixture at one part to nine parts $\mathrm{CO}_{2}$. No recommended application procedure was provided, so the same treatment procedure was used as with the Cleartene (for comparative purposes). Variability in the groove path and settling resulted in a lower initial gas permeability, but still flow through the groove was present as the permeability was substantially greater than that of the non-grooved tests. Low rate treatments and soaks repeated four times were not successful in improving the gas permeability. A high rate treatment with $200 \mathrm{ml}$ of the mixture showed some improvement over the initial but the permeability value was decreasing with continued flow until the gas rate was increased to $500 \mathrm{sccm}$. At this rate the permeability increased about six fold over the original value. To insure that this result was not a failure of the core or other situation other than true removal of the asphaltene, the test was repeated. 
Figure 20 - Attempt to Remove Asphaltene from Grooved Fractured Core Mixture of LS-489 and $\mathrm{CO}_{2}$

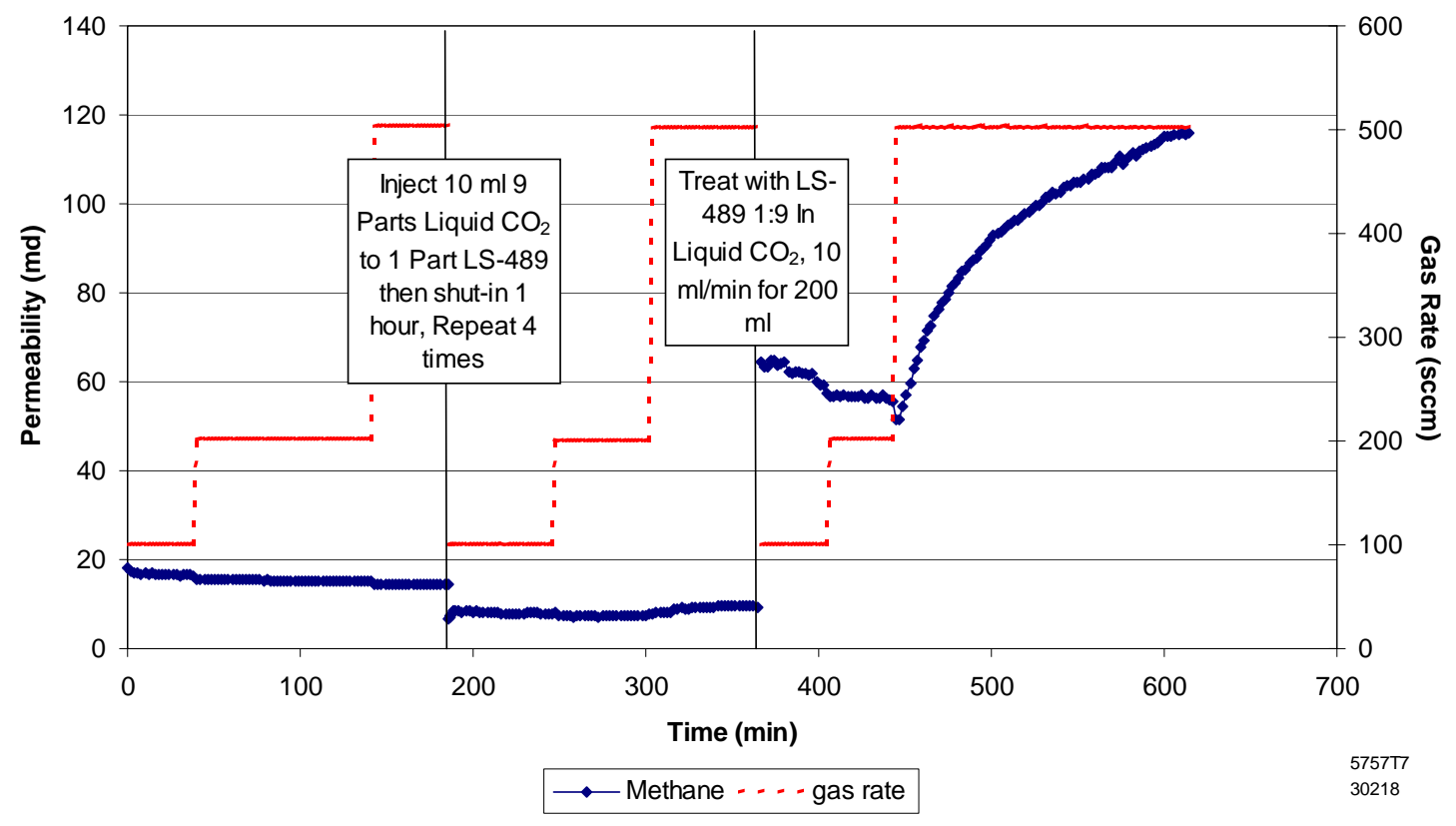

4. $\quad$ LS-489 and $\mathrm{CO}_{2}$ Repeat (Figure 21) - No more core material was available for the repeat test as many of the previous samples cracked or were damaged upon removal from the core holders. A core was obtained from a sample of low permeability quarried Edwards limestone for the repeat test. The core was cracked and prepared with a groove as with the previous test sample. Since the low flow rate treatments with alternating soak periods were not effective in the previous test, this was omitted and the high rate treatment was attempted first. At $10 \mathrm{ml} / \mathrm{min}$ (40 crack volumes/min), the treatment was not effective as in the previous test. Therefore, the treatment was repeated at a higher rate of $20 \mathrm{ml} / \mathrm{min}(80$ crack volumes/min). This higher rate treatment resulted in an improvement in the permeability. Unfortunately, the improvement was not as much as would be expected if the entire volume of asphaltene had been removed. This would indicate that a greater volume of the treatment or even higher flow rate may be needed to fully remove all of the material.

From the flow studies, it is apparent that the dried asphaltene appears to be very difficult to remove. None of the flow tests reached the permeability level expected if complete removal had occurred. Further, of the three solvents evaluated, straight treatments and soaks were ineffective as was the use of straight $\mathrm{CO}_{2}$. Combination mixtures of one part LS-489 and 9 parts $\mathrm{CO}_{2}$ showed some effectiveness. However, visual inspection of treated cores showed little change in the appearance of the asphaltene cake except for the $\mathrm{LS}-489 / \mathrm{CO}_{2}$ mixture where slight erosion of the cake around the groove was evident.

"Treatment of Hydrocarbon, Organic Residue and Production Chemical Damage Mechanisms Through the Application of Carbon Dioxide in Natural Gas Storage Wells” 
More testing and different solvent systems should be evaluated as results show that at least one treatment does have potential. Heating of the solvents to give more penetration should also be evaluated.

\section{Figure 21 - Test to Remove Asphaltene from Grooved Fractured Core Mixture of LS-489 and $\mathrm{CO}_{2}$ Repeat}

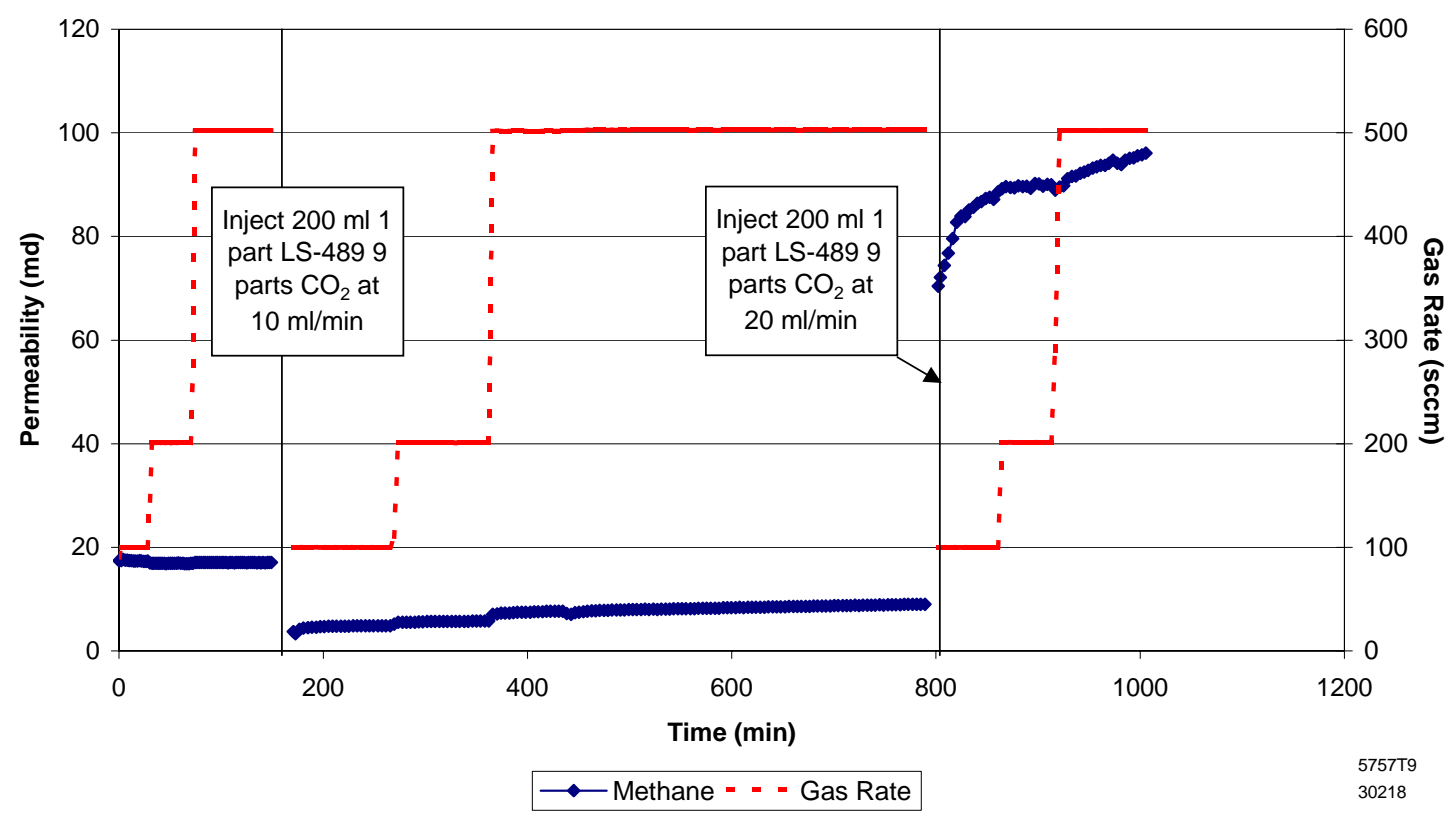

\section{Conclusions}

Characterization of bottomhole materials collected from Huntsman field demonstrated that contamination from surface materials such as valve grease and compressor oil is common in the field. Degraded crude oil is also a common constituent in Huntsman wells. These materials can effectively damage the productive formation, but supercritical $\mathrm{CO}_{2}$ is very effective in laboratory scale experiments in removing such damage. The results are directly relevant to the project objectives of determining the suitability of $\mathrm{CO}_{2}$ as a remediation fluid for hydrocarbon-based damage. These results further suggest that design and execution of a field demonstration to test the technology is justified.

Not all hydrocarbon-based damage is suitable for remediation by a $\mathrm{CO}_{2}$-based treatment, as suggested by experimental results from Overisel field specimens. Dried asphaltine was difficult to remove with either pure $\mathrm{CO}_{2}$ or in combination with commercial chemicals solvents. These results suggest that design and execution of a field-scale test for asphaltine removal is not justified. 


\title{
Recommendations
}

1. At Huntsman, install traps in injection lines to limit contamination upstream of wellhead.

2. Evaluate wellhead maintenance procedure to limit use of valve grease damage at Huntsman.

3. Develop a routine program of bailing and/or circulation of liquified/super critical $\mathrm{CO}_{2}$ in wellbores prior to summer injection at the Huntsman storage field.

\section{References}

1. Advanced Resources International, Inc.: "New and Novel Fracture Stimulation Technologies for the Revitalization of Existing Gas Storage Well: Liquid Carbon Dioxide with Proppant Fracturing,” Topical Report to the U.S. Department of Energy, national Energy Technology Laboratory (DE-AC21-94MC31112) and the Gas Research Institute (5097-270-4057), March, 2000.

2. Core Laboratory Report SCAL-307-83072, 1983.

3. $\quad$ Core Laboratory Report SCAL-307-83107, 1983.

4. $\quad$ Core Laboratory Report SCAL-307-83199, 1983.

5. $\quad$ Core Laboratory Report 3806-7122, 1984.

6. Penny, G. et al.: "The Mechanisms and Impact of Damage Resulting From Hydraulic Fracturing”, Topical report to the Gas Research Institute, August 1996, GRI-96/0183.

\section{List of Acronyms and Abbreviations}

\author{
${ }^{\circ} \mathrm{C}$ degrees Celsius \\ ${ }^{\circ} \mathrm{F} \quad$ degrees Fahrenheit \\ $\mathrm{CO}_{2}$ carbon dioxide \\ g/cc grams per cubic centimeter \\ gal gallon \\ $\mathrm{HCl}$ Hydrochlroic \\ $\mathrm{KCl}$ Potassium Chloride \\ md millidarcies \\ min minute \\ ml milliliter \\ psi pounds per square inch \\ sccm standard cubic centimeter \\ SCFm standard cubic feet per minute \\ XRD $x$-ray diffraction minute
}




\section{Appendix A}

\section{Huntsman Storage Well Sample Analyses}

"Treatment of Hydrocarbon, Organic Residue and Production Chemical Damage Mechanisms Through the Application of Carbon Dioxide in Natural Gas Storage Wells" 
Huntsman \#7 Sample Analysis

\begin{tabular}{|lc|}
\hline \multicolumn{2}{|c|}{ Description: $\begin{array}{c}\text { Brown dry powder with some scale } \\
\text { fragments and clay }\end{array}$} \\
\multicolumn{2}{|c|}{ Content Summary } \\
\hline Hydrocarbon & $8.3 \%$ \\
Moisture (volitiles) & $3.6 \%$ \\
Salt & $0.5 \%$ \\
Scales (includes calcite) & $33.7 \%$ \\
Formation Material & $54.3 \%$ \\
\hline
\end{tabular}

\begin{tabular}{|lc|}
\hline \multicolumn{2}{|c|}{ Classification of Sample Less Moisture } \\
\hline Water Solubility & $\mathbf{2 . 4 7 \%}$ \\
Water Soluble Minerals (salts etc.) & \\
$\mathbf{1 5 \%} \mathrm{HCl}$ Acid Solubility & $\mathbf{7 8 . 1 3 \%}$ \\
Represents acid soluble minerals + salts & \\
Xylene Solubility & $\mathbf{8 . 2 7 \%}$ \\
Represents hydrocarbon content & \\
Hexane solubility & $\mathbf{7 . 3 3 \%}$ \\
Hydrocarbon content less asphaltene & \\
Parrafin Content & $<1 \%$ \\
C18 and above & \\
Insoluble Content & $\mathbf{1 3 . 6 0 \%}$ \\
Fraction not soluble in xylene or acid & \\
Cl Content & $\mathbf{0 . 4 8 \%}$ \\
Reported as percentage NaCl & \\
\hline
\end{tabular}




\begin{tabular}{|c|c|c|c|c|c|}
\hline \multirow[b]{2}{*}{ Mineral } & \multicolumn{3}{|c|}{$\begin{array}{l}\text { XRD Analysis Well } 7 \text { Sample } \\
\text { Xylene and Water Insoluble Fraction }\end{array}$} & \multirow[b]{2}{*}{ Scale } & \multirow[b]{2}{*}{ Formation } \\
\hline & Formula & $\begin{array}{l}\text { Estimated } \\
\text { Percentage } \\
\end{array}$ & $\begin{array}{c}\text { Part of Total } \\
\text { Percentage }\end{array}$ & & \\
\hline Quartz & $\mathrm{SiO}_{2}$ & 55 & 48.2 & & 48.2 \\
\hline Feldspar & $(\mathrm{K}$ or $\mathrm{Na}) \mathrm{AlSi}_{3} \mathrm{O}_{8}$ & 1 & 0.9 & & 0.9 \\
\hline Calcite & $\mathrm{CaCO} 3$ & 0.5 & 0.4 & 0.4 & \\
\hline Siderite & $\mathrm{CaSO}_{4}$ & 14 & 12.3 & 12.3 & \\
\hline Hematite & $\mathrm{Fe}_{2} \mathrm{O}_{3}$ & 6 & 5.3 & 5.3 & \\
\hline Pyrite & $\mathrm{FeS}_{2}$ & 18 & 15.8 & 15.8 & \\
\hline Total Clay & - & 6 & 5.3 & 33.7 & $\begin{array}{c}5.3 \\
54.3<\text { Total }\end{array}$ \\
\hline
\end{tabular}

\begin{tabular}{|llr|}
\hline \multicolumn{2}{|c|}{ Xylene and $\mathrm{HCl}$ Acid Insoluble Fraction } \\
Mineral & \multicolumn{1}{c|}{ Formula } & $\begin{array}{c}\text { Estimated } \\
\text { Percentage }\end{array}$ \\
\hline Quartz & $\mathrm{SiO}_{2}$ & 79 \\
Feldspar & $\left({\mathrm{K} \mathrm{or} \mathrm{Na}) \mathrm{AlSi}_{3} \mathrm{O}_{8}}_{1}\right.$ \\
Pyrite & $\mathrm{FeS}_{2}$ & 9 \\
Hematite & $\mathrm{Fe}_{2} \mathrm{O}_{3}$ & 2 \\
Siderite & $\mathrm{FeCO}_{3}$ & 2 \\
Total Clay & & 7 \\
\hline
\end{tabular}


Huntsman \#8 Sample Analysis

\begin{tabular}{|lc|}
\hline \multicolumn{2}{|c|}{ Description: } \\
\multicolumn{2}{|c|}{ Content Summary } \\
\hline \multicolumn{2}{|c|}{ Teflon tape } \\
\hline Hydrocarbon & $7.1 \%$ \\
Moisture (volitiles) & $1.7 \%$ \\
Salt & $0.8 \%$ \\
Scales (includes calcite) & $3.2 \%$ \\
Formation Material & $87.3 \%$ \\
\hline
\end{tabular}

\begin{tabular}{|lc|}
\hline \multicolumn{2}{|c|}{ Classification of Sample Less Moisture } \\
\hline Water Solubility & $0.75 \%$ \\
Water Soluble Minerals (salts etc.) & \\
$15 \% \mathrm{HCl}$ Acid Solubility & $\mathbf{4 8 . 7 3 \%}$ \\
Represents acid soluble minerals + salts & \\
Xylene Solubility & $\mathbf{7 . 0 8 \%}$ \\
Represents hydrocarbon content & \\
Hexane solubility & $6.95 \%$ \\
Hydrocarbon content less asphaltene & \\
Parrafin Content & $<1 \%$ \\
C18 and above & \\
Insoluble Content & \\
Fraction not soluble in xylene or acid & \\
Cl Content & $0.75 \%$ \\
Reported as percentage NaCl & \\
\hline
\end{tabular}




\begin{tabular}{|c|c|c|c|c|c|}
\hline \multirow[b]{2}{*}{ Mineral } & \multicolumn{3}{|c|}{$\begin{array}{l}\text { XRD Analysis Well } 8 \text { Sample } \\
\text { Xylene and Water Insoluble Fraction }\end{array}$} & \multirow[b]{2}{*}{ Scale } & \multirow[b]{2}{*}{ Formation } \\
\hline & Formula & $\begin{array}{l}\text { Estimated } \\
\text { Percentage }\end{array}$ & $\begin{array}{l}\text { Part of Total } \\
\text { Percentage }\end{array}$ & & \\
\hline Quartz & $\mathrm{SiO}_{2}$ & 91 & 82.4 & & 82.4 \\
\hline Feldspar & $(\mathrm{K}$ or $\mathrm{Na}) \mathrm{AlSi}_{3} \mathrm{O}_{8}$ & 1.5 & 1.4 & & 1.4 \\
\hline Calcite & $\mathrm{CaCO} 3$ & 0.5 & 0.5 & 0.5 & \\
\hline Siderite & $\mathrm{CaSO}_{4}$ & 1 & 0.9 & 0.9 & \\
\hline Hematite & $\mathrm{Fe}_{2} \mathrm{O}_{3}$ & 1 & 0.9 & 0.9 & \\
\hline Pyrite & $\mathrm{FeS}_{2}$ & 1 & 0.9 & 0.9 & \\
\hline Total Clay & - & 4 & 3.6 & & 3.6 \\
\hline & & & & 3.2 & $87.3<$ Total \\
\hline
\end{tabular}

\begin{tabular}{|c|c|c|}
\hline Xylene & $\mathrm{HCl}$ Acid Insolub & $\begin{array}{l}\text { Eraction } \\
\text { Estimated } \\
\text { Percentage }\end{array}$ \\
\hline Quartz & $\mathrm{SiO}_{2}$ & 92 \\
\hline Feldspar & $(\mathrm{K}$ or $\mathrm{Na}) \mathrm{AlSi}_{3} \mathrm{O}_{8}$ & 2 \\
\hline Pyrite & $\mathrm{FeS}_{2}$ & 1 \\
\hline Total Clay & - & 5 \\
\hline
\end{tabular}


Huntsman \#10 Sample Analysis

\begin{tabular}{|lc|}
\hline \multicolumn{2}{|c|}{ Description: } \\
\multicolumn{2}{|c|}{ Content Summary } \\
clumps \\
\hline Hydrocarbon & $51.6 \%$ \\
Salt & $6.5 \%$ \\
Scales (includes calcite) & $17.6 \%$ \\
Formation Material & $24.3 \%$ \\
\hline
\end{tabular}

\begin{tabular}{|lc|}
\hline \multicolumn{2}{|c|}{ Classification of Sample Less Moisture } \\
\hline Water Solubility & $6.74 \%$ \\
Water Soluble Minerals (salts etc.) & \\
15\% HCl Acid Solubility & $9.64 \%$ \\
Represents acid soluble minerals + salts & \\
Xylene Solubility & $51.60 \%$ \\
Represents hydrocarbon content & \\
Hexane solubility \\
Hydrocarbon content less asphaltene \\
$\begin{array}{l}\text { Parrafin Content } \\
\text { C18 and above }\end{array}$ \\
$\begin{array}{l}\text { Insoluble Content } \\
\text { Fraction not soluble in xylene or acid } \\
\text { Cl Content } \\
\text { Reported as percentage NaCl }\end{array}$ \\
\hline
\end{tabular}




\begin{tabular}{|c|c|c|c|c|c|}
\hline \multirow[b]{2}{*}{ Mineral } & \multicolumn{3}{|c|}{$\begin{array}{l}\text { XRD Analysis Well } 10 \text { Sample } \\
\text { Xylene and Water Insoluble Fraction }\end{array}$} & \multirow[b]{2}{*}{ Scale } & \multirow[b]{2}{*}{ Formation } \\
\hline & Formula & $\begin{array}{l}\text { Estimated } \\
\text { Percentage }\end{array}$ & $\begin{array}{l}\text { Part of Total } \\
\text { Percentage }\end{array}$ & & \\
\hline Quartz & $\mathrm{SiO}_{2}$ & 29 & 12.1 & & 12.1 \\
\hline Feldspar & $(\mathrm{K}$ or $\mathrm{Na}) \mathrm{AlSi}_{3} \mathrm{O}_{8}$ & 3 & 1.3 & & 1.3 \\
\hline Calcite & $\mathrm{CaCO} 3$ & 2 & 0.8 & 0.8 & \\
\hline Magnetite & $\mathrm{Fe}_{3} \mathrm{O}_{4}$ & 21 & 8.8 & 8.8 & \\
\hline Mackinawite & $\mathrm{Fe}_{9} \mathrm{~S}_{8}$ & 2 & 0.8 & 0.8 & \\
\hline Pyrite & $\mathrm{FeS}_{2}$ & Trace & Trace & Trace & \\
\hline Hematite & $\mathrm{Fe}_{2} \mathrm{O}_{3}$ & 2 & 0.8 & 0.8 & \\
\hline Siderite & $\mathrm{FeCO}_{3}$ & 6 & 2.5 & 2.5 & \\
\hline Anhydrite & $\mathrm{CaSO}_{4}$ & 8 & 3.3 & 3.3 & \\
\hline Ankerite & $\mathrm{Ca}(\mathrm{Mg}, \mathrm{Fe})\left(\mathrm{CO}_{3}\right)_{2}$ & 1 & 0.4 & 0.4 & \\
\hline Total Clay & - & 26 & 10.9 & & 10.9 \\
\hline & & & & 17.6 & $24.3<$ Tota \\
\hline
\end{tabular}

\begin{tabular}{|c|c|c|}
\hline $\begin{array}{l}\text { Xylene } \\
\text { Mineral }\end{array}$ & $\mathrm{HCl}$ Acid Insolub & $\begin{array}{l}\text { Fraction } \\
\text { Estimated } \\
\text { Percentage }\end{array}$ \\
\hline Quartz & $\mathrm{SiO}_{2}$ & 48 \\
\hline Feldspar & $(\mathrm{K}$ or $\mathrm{Na}) \mathrm{AlSi}_{3} \mathrm{O}_{8}$ & 5 \\
\hline Magnetite & $\mathrm{Fe}_{3} \mathrm{O}_{4}$ & 8 \\
\hline Mackinawite & $\mathrm{Fe}_{9} \mathrm{~S}_{8}$ & 2 \\
\hline Pyrite & $\mathrm{FeS}_{2}$ & 6 \\
\hline Hematite & $\mathrm{Fe}_{2} \mathrm{O}_{3}$ & 3 \\
\hline Siderite & $\mathrm{FeCO}_{3}$ & 1 \\
\hline Total Clay & - & 27 \\
\hline
\end{tabular}


$\underline{\text { Huntsman \#21 Sample Analysis }}$

\begin{tabular}{|lc|}
\hline Description: & $\begin{array}{c}\text { Dark gray, powdery with clumps, } \\
\text { silica and scale visible }\end{array}$ \\
\multicolumn{2}{|c|}{ Content Summary } \\
\hline Hydrocarbon & $17.8 \%$ \\
Salt & $<0.1 \%$ \\
Scales & $61.6 \%$ \\
Formation Material & $20.5 \%$ \\
\hline
\end{tabular}

\begin{tabular}{|c|c|}
\hline \multicolumn{2}{|c|}{ Classification of Sample Less Moisture } \\
\hline $\begin{array}{l}\text { Water Solubility } \\
\text { Water Soluble Minerals (salts, etc.) }\end{array}$ & $2.28 \%$ \\
\hline $\begin{array}{l}\text { 15\% HCl Acid Solubility } \\
\text { Represents acid soluble minerals + salts }\end{array}$ & $22.25 \%$ \\
\hline $\begin{array}{l}\text { Xylene Solubility } \\
\text { Represents hydrocarbon content }\end{array}$ & $17.82 \%$ \\
\hline $\begin{array}{l}\text { Hexane Solubility } \\
\text { Hydrocarbon content less asphaltene }\end{array}$ & $14.17 \%$ \\
\hline $\begin{array}{l}\text { Parrafin Content } \\
\text { C18 and above }\end{array}$ & $0.13 \%$ \\
\hline $\begin{array}{l}\text { Insoluble Content } \\
\text { Fraction not soluble in xylene or acid }\end{array}$ & $59.93 \%$ \\
\hline $\begin{array}{l}\mathrm{Cl} \text { Content } \\
\text { Reported as percentage } \mathrm{NaCl}\end{array}$ & $<0.1 \%$ \\
\hline
\end{tabular}




\begin{tabular}{|c|c|c|c|c|c|}
\hline \multirow[b]{2}{*}{ Mineral } & \multicolumn{3}{|c|}{$\begin{array}{c}\text { XRD Analysis Well } 21 \\
\text { Xylene and Water Insoluble Fraction }\end{array}$} & \multirow[b]{2}{*}{ Scale } & \multirow[b]{2}{*}{ Formation } \\
\hline & Formula & $\begin{array}{c}\text { Estimated } \\
\text { Percentage }^{*}\end{array}$ & $\begin{array}{c}\text { Part of Total } \\
\text { Percentage }\end{array}$ & & \\
\hline Quartz & $\mathrm{SiO}_{2}$ & 25 & 20.5 & & 20.5 \\
\hline Magnetite & $\mathrm{Fe}_{3} \mathrm{O}_{4}$ & 25 & 20.5 & 20.5 & \\
\hline Mackinawite & $\mathrm{Fe}_{9} \mathrm{~S}_{8}$ & 25 & 20.5 & 20.5 & \\
\hline Pyrite & $\mathrm{FeS}_{2}$ & 10 & 8.2 & 8.2 & \\
\hline Siderite & $\mathrm{FeCO}_{3}$ & 10 & 8.2 & 8.2 & \\
\hline Anhydrite & $\mathrm{CaSO}_{4}$ & 5 & 4.1 & 4.1 & \\
\hline Barite - ? & $\mathrm{BaSO}_{4}$ & Trace & Trace & Trace & \\
\hline Sulfur - ? & $\mathrm{S}$ & Trace & Trace & Trace & \\
\hline Total Clays & - & Trace & Trace & $\begin{array}{r}\text { Trace } \\
61.6\end{array}$ & $20.5<$ Total \\
\hline
\end{tabular}

\begin{tabular}{|c|c|c|}
\hline \multicolumn{3}{|c|}{ Xylene and $\mathrm{HCl}$ Acid Insoluble Fraction } \\
\hline Mineral & Formula & $\begin{array}{l}\text { Estimated } \\
\text { Percentage }\end{array}$ \\
\hline Quartz & $\mathrm{SiO}_{2}$ & 54 \\
\hline Feldspar & $(\mathrm{K}$ or $\mathrm{Na}) \mathrm{AlSi}_{3} \mathrm{O}_{8}$ & 4 \\
\hline Magnetite & $\mathrm{Fe}_{3} \mathrm{O}_{4}$ & 21 \\
\hline Mackinawite & $\mathrm{Fe}_{9} \mathrm{~S}_{8}$ & 12 \\
\hline Pyrite & $\mathrm{FeS}_{2}$ & 5 \\
\hline Siderite & $\mathrm{FeCO}_{3}$ & 1 \\
\hline Total Clay & - & 3 \\
\hline
\end{tabular}


Huntsman \#23 Sample Analysis

\begin{tabular}{|lc|}
\hline \multicolumn{1}{|c|}{ Description: } & $\begin{array}{c}\text { Mostly quartz grains with dark gray } \\
\text { fragments, damp }\end{array}$ \\
& \multicolumn{2}{|c|}{ Content Summary } \\
\hline Hydrocarbon & $1.9 \%$ \\
Salt & $1.5 \%$ \\
Scales & $3.9 \%$ \\
Formation Material or Frac Sand & $92.7 \%$ \\
\hline
\end{tabular}

\begin{tabular}{|lc|}
\hline \multicolumn{2}{|c|}{ Classification of Sample Less Moisture } \\
\hline Water Solubility & $5.65 \%$ \\
Water Soluble Minerals (salts etc.) & \\
$\mathbf{1 5 \%} \mathrm{HCl}$ Acid Solubility & $\mathbf{7 . 5 3 \%}$ \\
Represents acid soluble minerals + salts & $\mathbf{1 . 8 6 \%}$ \\
$\begin{array}{l}\text { Xylene Solubility } \\
\text { Represents hydrocarbon content }\end{array}$ & $\mathbf{9 0 . 6 1 \%}$ \\
Insoluble Content & \\
Fraction not soluble in xylene or acid \\
Microscopic examination suggests mostly $20 / 40$ frac Sand \\
Cl Content & $1.50 \%$ \\
Reported as percentage NaCl & \\
\hline
\end{tabular}




\begin{tabular}{|c|c|c|c|c|c|}
\hline \multirow[b]{2}{*}{ Mineral } & \multicolumn{3}{|c|}{$\begin{array}{c}\text { XRD Analysis Well } 23 \\
\text { Xylene and Water Insoluble Fraction }\end{array}$} & \multirow[b]{2}{*}{ Scale } & \multirow[b]{2}{*}{ Formation } \\
\hline & Formula & $\begin{array}{l}\text { Estimated } \\
\text { Percentage }\end{array}$ & $\begin{array}{l}\text { Part of Total } \\
\text { Percentage } \\
\end{array}$ & & \\
\hline Quartz & $\mathrm{SiO}_{2}$ & 95 & 91.8 & & 91.8 \\
\hline Feldspar & $(\mathrm{K}$ or $\mathrm{Na}) \mathrm{AlSi}_{3} \mathrm{O}_{8}$ & Trace & Trace & & \\
\hline Calcite & $\mathrm{CaCO} 3$ & Trace & Trace & & \\
\hline Magnetite & $\mathrm{Fe}_{3} \mathrm{O}_{4}$ & 0 & 0.0 & & \\
\hline Mackinawite & $\mathrm{Fe}_{9} \mathrm{~S}_{8}$ & 0 & 0.0 & & \\
\hline Pyrite & $\mathrm{FeS}_{2}$ & 2 & 1.9 & 1.9 & \\
\hline Hematite & $\mathrm{Fe}_{2} \mathrm{O}_{3}$ & 0 & 0.0 & & \\
\hline Siderite & $\mathrm{FeCO}_{3}$ & 2 & 1.9 & 1.9 & \\
\hline Anhydrite & $\mathrm{CaSO}_{4}$ & 0 & 0.0 & & \\
\hline Ankerite & $\mathrm{Ca}(\mathrm{Mg}, \mathrm{Fe})\left(\mathrm{CO}_{3}\right)_{2}$ & Trace & Trace & Trace & \\
\hline Total Clay & - & 1 & 1.0 & & 1.0 \\
\hline & & & & 3.9 & $92.7<$ Total \\
\hline
\end{tabular}

\begin{tabular}{|c|c|c|}
\hline \multicolumn{3}{|c|}{ Xylene and $\mathrm{HCl}$ Acid Insoluble Fraction } \\
\hline Mineral & Formula & $\begin{array}{l}\text { Estimated } \\
\text { Percentage }\end{array}$ \\
\hline Quartz & $\mathrm{SiO}_{2}$ & 98 \\
\hline Total Clay & - & 2 \\
\hline
\end{tabular}


Huntsman \#30 Sample Analysis

\begin{tabular}{|lc|}
\hline \multirow{2}{*}{ Description: } & Tan-black moist sludge \\
\multicolumn{2}{|c|}{ Content Summary } \\
\hline Hydrocarbon & $11.8 \%$ \\
Moisture (volitiles) & $69.4 \%$ \\
Salt & $0.5 \%$ \\
Scales (includes calcite) & $10.3 \%$ \\
Formation Material & $8.0 \%$ \\
\hline
\end{tabular}

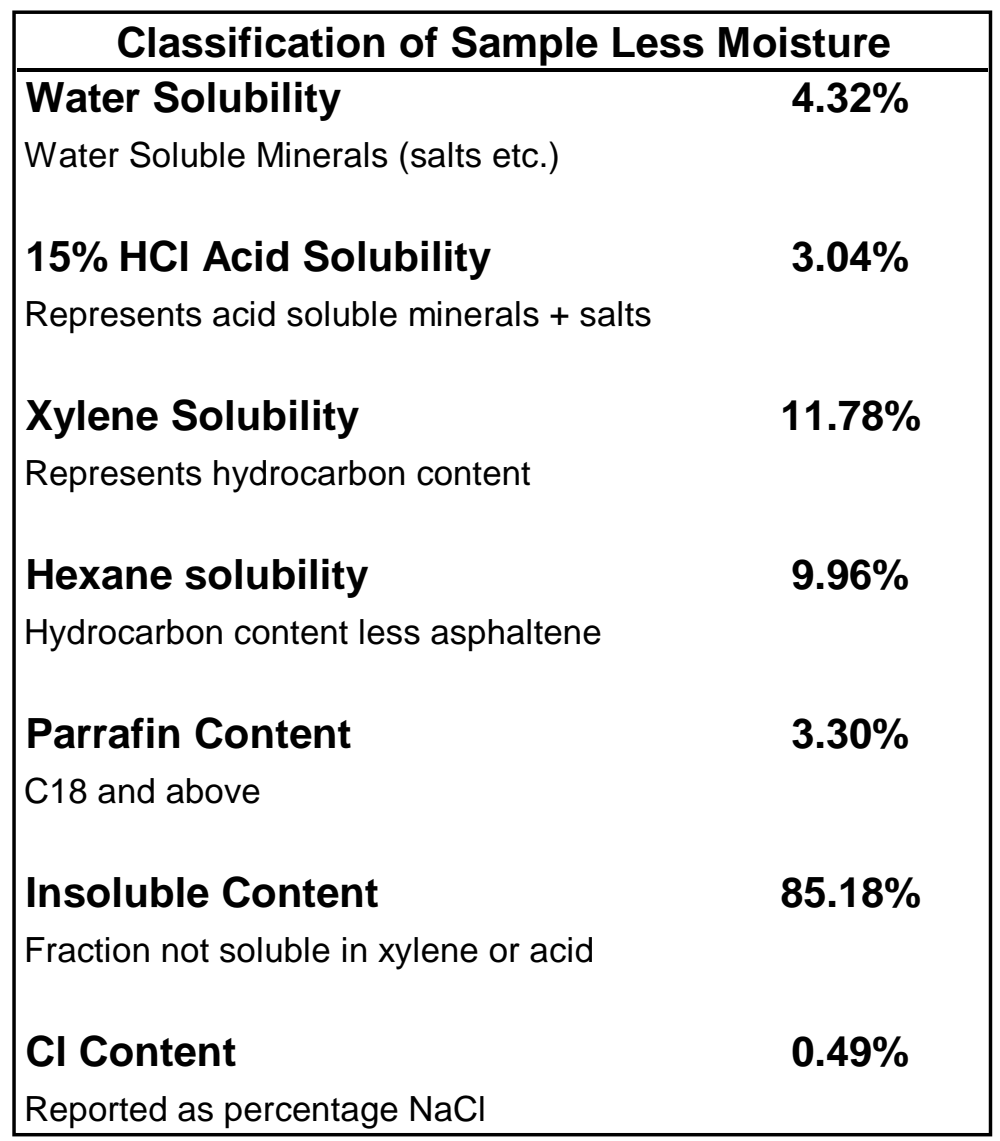




\begin{tabular}{|c|c|c|c|c|c|}
\hline \multirow[b]{2}{*}{ Mineral } & \multicolumn{3}{|c|}{$\begin{array}{l}\text { XRD Analysis Well } 30 \text { Sample } \\
\text { Xylene and Water Insoluble Fraction }\end{array}$} & \multirow[b]{2}{*}{ Scale } & \multirow[b]{2}{*}{ Formation } \\
\hline & Formula & $\begin{array}{l}\text { Estimated } \\
\text { Percentage }\end{array}$ & $\begin{array}{l}\text { Part of Total } \\
\text { Percentage }\end{array}$ & & \\
\hline Quartz & $\mathrm{SiO}_{2}$ & 25 & 4.6 & & 4.6 \\
\hline Feldspar & $(\mathrm{K}$ or $\mathrm{Na}) \mathrm{AlSi}_{3} \mathrm{O}_{8}$ & 0.5 & 0.1 & & 0.1 \\
\hline Calcite & $\mathrm{CaCO} 3$ & 43 & 7.9 & 7.9 & \\
\hline Gypsum & $\mathrm{CaSO}_{4}$ & 4 & 0.7 & 0.7 & \\
\hline Bassinite & $\mathrm{CaSO}_{4}$ & 9 & 1.6 & 1.6 & \\
\hline Pyrite & $\mathrm{FeS}_{2}$ & 0.5 & 0.1 & 0.1 & \\
\hline Total Clay & - & 18 & 3.3 & & 3.3 \\
\hline & & & & 10.3 & $8.0<$ Total \\
\hline
\end{tabular}

\begin{tabular}{|c|c|c|}
\hline Xylene & $\mathrm{HCl}$ Acid Insolub & $\begin{array}{l}\text { Eaction } \\
\text { Estimated } \\
\text { Percentage }\end{array}$ \\
\hline Quartz & $\mathrm{SiO}_{2}$ & 82 \\
\hline Feldspar & $(\mathrm{K}$ or $\mathrm{Na}) \mathrm{AlSi}_{3} \mathrm{O}_{8}$ & 6 \\
\hline Calcite & $\mathrm{CaCO}_{3}$ & 1 \\
\hline Pyrite & $\mathrm{FeS}_{2}$ & 2 \\
\hline Anhydrite & $\mathrm{CaSO}_{4}$ & 4 \\
\hline Talc & & 1 \\
\hline Total Clay & - & 4 \\
\hline
\end{tabular}


Huntsman \#44 Sample Analysis

\begin{tabular}{|lc|}
\hline \multirow{2}{*}{ Description: } & Gray to black oily solid \\
\multicolumn{2}{|c|}{ Content Summary } \\
\hline Hydrocarbon & $8.3 \%$ \\
Moisture (volitiles) & $13.6 \%$ \\
Salt & $1.2 \%$ \\
Scales (includes calcite) & $5.4 \%$ \\
Formation Material & $71.5 \%$ \\
\hline
\end{tabular}

\begin{tabular}{|c|c|}
\hline \multicolumn{2}{|c|}{ Classification of Sample Less Moisture } \\
\hline $\begin{array}{l}\text { Water Solubility } \\
\text { Water Soluble Minerals (salts etc.) }\end{array}$ & $0.75 \%$ \\
\hline $\begin{array}{l}15 \% \mathrm{HCl} \text { Acid Solubility } \\
\text { Represents acid soluble minerals + salts }\end{array}$ & $37.59 \%$ \\
\hline $\begin{array}{l}\text { Xylene Solubility } \\
\text { Represents hydrocarbon content }\end{array}$ & $8.30 \%$ \\
\hline $\begin{array}{l}\text { Hexane solubility } \\
\text { Hydrocarbon content less asphaltene }\end{array}$ & $7.15 \%$ \\
\hline $\begin{array}{l}\text { Parrafin Content } \\
\text { C18 and above }\end{array}$ & $2.32 \%$ \\
\hline $\begin{array}{l}\text { Insoluble Content } \\
\text { Fraction not soluble in xylene or acid }\end{array}$ & $54.11 \%$ \\
\hline $\begin{array}{l}\mathrm{Cl} \text { Content } \\
\text { Reported as percentage } \mathrm{NaCl}\end{array}$ & $1.20 \%$ \\
\hline
\end{tabular}




\begin{tabular}{|llrrrr|}
\hline \multicolumn{7}{c|}{ XRD Analysis Well 44 Sample } \\
\multicolumn{1}{c}{ Xylene and Water Insoluble Fraction } \\
Mineral & \multicolumn{1}{c|}{ Formula } & $\begin{array}{r}\text { Estimated } \\
\text { Percentage }\end{array}$ & $\begin{array}{c}\text { Part of Total } \\
\text { Percentage }\end{array}$ & Scale & Formation \\
\hline Quartz & $\mathrm{SiO}_{2}$ & 45 & 34.6 & & 34.6 \\
Feldspar & $\left(\mathrm{K} \mathrm{or} \mathrm{Na)AlSi}_{3} \mathrm{O}_{8}\right.$ & 4 & 3.1 & & 3.1 \\
Calcite & $\mathrm{CaCO}^{2}$ & 2 & 1.5 & 1.5 & \\
Siderite & $\mathrm{CaSO}_{4}$ & 1 & 0.8 & 0.8 & \\
Hematite & $\mathrm{Fe}_{2} \mathrm{O}_{3}$ & 0 & 0.0 & 0.0 & \\
Pyrite & $\mathrm{FeS}_{2}$ & 4 & 3.1 & 3.1 & \\
Total Clay & & 44 & 33.8 & & 33.8 \\
& & & & 5.4 & $71.5<$ Total \\
\hline
\end{tabular}

\begin{tabular}{|llr|}
\hline \multicolumn{2}{|c|}{ Xylene and $\mathrm{HCl}$ Acid Insoluble Fraction } \\
Mineral & \multicolumn{1}{c|}{ Formula } & $\begin{array}{c}\text { Estimated } \\
\text { Percentage }\end{array}$ \\
\hline Quartz & $\mathrm{SiO}_{2}$ & 58 \\
Feldspar & $\left({\mathrm{K} \mathrm{or} \mathrm{Na}) \mathrm{AlSi}_{3} \mathrm{O}_{8}}_{7}\right.$ \\
Calcite & $\mathrm{CaCO}_{3}$ & 0.5 \\
Pyrite & $\mathrm{FeS}_{2}$ & 4 \\
Siderite & $\mathrm{FeCO}_{3}$ & 0.5 \\
Total Clay & & 30 \\
\hline
\end{tabular}




\section{Appendix B}

\section{Petrographic Analysis of Selected Samples from Huntsman Storage Well \#26}




\title{
PETROGRAPHIC ANALYSIS OF SELECTED SAMPLES FROM THE HUNTSMAN STORAGE NO. 26 CHEYENNE, NEBRASKA
}

Prepared for:

\author{
ADVANCED RESOURCES INTERNATIONAL \\ 1110 N. GLEBE ROAD \\ ARLINGTON, VA 22201
}

Prepared by:

\author{
STIM-LAB, INC. \\ 7406 NORTH HWY 81 \\ DUNCAN, OKLAHOMA 73533-1644
}

P.O. NUMBER: VERBAL/

FILE NUMBER: SL 5757

JANUARY 30, 2002

\begin{abstract}
ALL INTERPRETATIONS ARE OPINIONS BASED ON INFERENCES FROM SAMPLES AND LOGS, WHICH WERE SUPPLIED. WE CANNOT, AND DO NOT, GUARANTEE THE ACCURACY OR CORRECTNESS OF ANY INTERPRETATIONS, AND WE SHALL NOT, EXCEPT IN THE CASE OF GROSS OR WILLFUL NEGLIGENCE ON OUR PART, BE LIABLE OR RESPONSIBLE FOR ANY LOSS, COSTS, DAMAGES OR EXPENSES INCURRED OR SUSTAINED BY ANYONE RESULTING FROM ANY INTERPRETATION MADE BY ANY OF OUR OFFICERS, AGENTS OR EMPLOYEES. THESE INTERPRETATIONS ARE ALSO SUBJECT TO OUR GENERAL TERMS AND CONDITIONS AS SET OUT IN OUR CURRENT PRICE SCHEDULE.
\end{abstract}




\section{CORE ANALYSIS REPORT}

\section{INTRODUCTION}

Routine core analysis was performed on two conventional core samples from the KN Energy Huntsman Storage No. 26 IN Cheyenne, Nebraska. Results are presented in this report.

\section{SAMPLE PREPARATION}

PLUG PREPARATION: The core plugs were drilled with a 1” diameter diamond tipped core barrel cooled with water. The plugs were trimmed using a saw equipped with diamond blades. The plugs were faced with a diamond-facing tool to provide right circular cylinders.

SAMPLE CLEANING: The samples were extracted of hydrocarbons in a soxhlet extractor. Toluene was used as the refluxing solvent. Extraction was continued until the returning solvent was clear.

SAMPLE DRYING: The samples were dried in a convection oven at $240^{\circ} \mathrm{F}$ for 24 hours.

\section{PERMEABILITY MEASUREMENT WITH CMS-300}

Conventional core samples are analyzed using the CMS-300 automated core measurement system that incorporates a porosimeter and permeameter into one instrument. The CMS-300 system performs computer-controlled, unsteady state, pressure-transient measurements of reservoir rock pore volumes, porosity, Klinkenberg permeability, Forchheimer inertial factor and Klinkenberg slip factor at up to eight specified confining pressures between 500 psi and 10,000 psi. This allows measurements to be made at overburden pressures more representative of reservoir conditions. Helium is the test gas used.

POROSITY: Porosity is defined as the ratio of the pore volume to the bulk volume of material.

Pore Volume (Volume Of Helium Injected Into the Pore Space by the CMS)

Porosity $=\quad$ Bulk Volume (Volume Of The Plug As Determined By A Fowler Ultra-Call Mark III Digital Caliper)

This equation corrects for bulk volume reduction as overburden pressure is applied.

PERMEABILITY: Permeability is a measure of the ability of a porous material to transmit fluid.

Kinf $=$ Klinkenberg corrected permeability. Equivalent, non-reactive, liquid permeability determined by the CMS at up to eight designated, net-overburden, confining stresses. This is an improved flow capacity indicator since gas slippage effects present at low laboratory pore pressure (and not at reservoir conditions) have been eliminated. 

Kair = A calculated air permeability approximating historical core analysis permeability data. Kair is an optimistic value. Low pressures in historical laboratory measurements result in gas slippage not present at reservoir conditions and create artificially high permeability values.

GRAIN DENSITY: Calculated grain densities were obtained utilizing bulk volume and pore volume measurements and clean, dry sample weights. Grain densities were checked against lithology standards.

\section{Routine Core Analysis Results}

\begin{tabular}{|c|c|c|c|c|c|}
\hline \multirow[b]{2}{*}{$\begin{array}{c}\text { Sample } \\
\text { ID }\end{array}$} & \multirow[b]{2}{*}{$\begin{array}{c}\text { Depth } \\
\text { (feet) }\end{array}$} & \multirow{2}{*}{$\begin{array}{c}\text { Helium } \\
\text { Porosity } \\
\% \\
\end{array}$} & \multicolumn{2}{|c|}{ Permeability (800psi) } & \multirow{2}{*}{$\begin{array}{c}\text { Grain } \\
\text { Density } \\
\text { g/cc } \\
\end{array}$} \\
\hline & & & $\begin{array}{c}\text { Air } \\
\text { (md) }\end{array}$ & $\begin{array}{c}\text { Klinkenberg } \\
\text { (md) }\end{array}$ & \\
\hline 1 & 4830 & 17.9 & 41.1 & 38.5 & 2.62 \\
\hline 2 & 4861 & 19.3 & 249 & 248 & 2.59 \\
\hline
\end{tabular}




\section{PETROGRAPHic report}

\section{INTRODUCTION}

Thin section petrography, scanning electron microscopy with energy dispersive spectrometry (SEM/EDS) and X-ray diffraction analysis were performed on two conventional core samples from the KN Energy Huntsman Storage No. 26 in Cheyenne, Nebraska. The purpose of this study is to describe the mineralogical and textural characteristics of these samples.

\section{METHOD}

\section{Thin Section Petrography}

Thin section petrography provides the best overall characterization of the rock samples. Selected samples are impregnated with a low viscosity, blue epoxy prior to mounting on a glass slide. After mounting, the samples are ground to a uniform thickness of 30 microns. Thin sections have been stained with Alizarin Red-S and potassium ferricyanide stains for easier identification of calcite and ferroan carbonate minerals.

Most mineral and amorphous phases can be identified, and visual estimates of porosity types are possible from the thin sections. Grain size, sorting and other textural characteristics can also be accurately estimated. Observations are documented in the data sheets and photomicrographs presented later in the report.

\section{Scanning Electron Microscopy}

The scanning electron microscope (SEM) provides a three-dimensional view of grain surfaces and pores. Freshly fractured surfaces of selected sample are used for SEM analysis. The samples are sputter coated with gold-palladium and photographs document the observations. High magnifications, coupled with energy dispersive x-ray spectrometry (EDS), allow for the identification of clay-size materials.

\section{X-Ray Diffraction Analysis}

X-ray diffraction analysis (XRD) provides excellent qualitative mineral identification and semiquantitative compositions by weight of the crystalline components of the rock samples. A complete procedure requires separate analysis of the "bulk" sample and the "clay" fraction. A table of compositions determined by XRD is presented in the report.

The representative samples selected for "bulk" analysis are first cleaned of surface contamination and ground until all of the material passes through a 200-mesh screen. Next, the sample is ground in acetone to produce a uniform powder of 10 to 50 micron particles. The powdered rock is lightly packed in a sample holder and scanned from 2 to 45 degrees 2-theta by step scanning 0.05 degrees 2-theta for 5 seconds. The counts at each step are directly collected by and stored in the computer for later analysis.

Analysis of the clay fraction begins by disaggregation of fine-grained material in water with ultrasonication. The suspended material is centrifuged to separate the particles by size. Particles less than 5 microns in size are filtered out of suspension. The filtered clays are transferred to a glass slide and scanned from 2 to 40 degrees 2-theta by step scanning as above. If swelling clays appear to be present, they are confirmed by saturating the clays with ethylene glycol vapor. The slide is then rescanned. 


\section{PETROGRAPHIC DESCRIPTION}

\section{0 feet - Sublitharenite}

The sandstone sample at 4830 feet is a sublitharenite to quartzarenite. Quartz is the most abundant framework grain, but rock fragments and chert occur in minor to moderate amounts. Also present are minor to trace amounts of feldspars (mostly plagioclase), micas, heavy minerals and organic material. Detrital clays are present in trace amounts and ductile grains have been deformed into pseudomatrix. Authigenic minerals include quartz overgrowths, carbonate cements (calcite and ferroan dolomite), pyrite and clays.

The sample is a very fine-grained, moderately to well sorted sandstone. Average grain size is about 95 microns. Elongate grains exhibit a slight preferred orientation. Detrital grains are mostly subangular to subround and have long to tangential grain-to-grain contacts.

The rock has minor amounts of clay cements. Clay content (detrital and authigenic) is 3 percent of the whole rock by XRD. Authigenic clay minerals present in the examined samples are mostly illite, kaolinite and chlorite. Authigenic clays are present as grain-coating, pore-lining and porefilling minerals. Detrital clays appear to be illitic (SEM observations). The abundance of clay minerals, particularly illite, will increase irreducible water saturations, resulting in low resistivity log measurements for this reservoir. Illite, with its high surface area, creates large volumes of microporosity in which to bind formation water. The presence of kaolinite could contribute fines available for migration to pore throats.

Minor quartz overgrowths are observed at grain contacts. When found, quartz overgrowth cement is observed as euhedral crystals that coat detrital grains. Other trace, authigenic minerals include grain-replacive and pore-filling calcite, ferroan dolomite (ankerite) and pyrite. Porefilling ankerite appears to b concentrated along a diffuse lamina.

At 4830 feet, routine porosity and permeability measurements report porosity to be $17.9 \%$ and klinkenberg permeability to be $38.5 \mathrm{md}$. Visual estimates are slightly lower and most likely due to fair amounts of microporosity associated with clays. Intergranular pores are common and average about 50 o 70 microns in diameter. Some secondary dissolution pores are also observed and on the order of 100 microns across, but range up to 250 microns.

\section{1 feet - Sublitharenite to Quartarenite}

The sandstone sample at 4860.1 feet is a sublitharenite to quartzarenite. Quartz is the most abundant framework grain, but feldspars (plagioclase and potassium feldspars), rock fragments (mostly argillaceous) and chert occur in minor amounts. Also present are trace amounts of heavy minerals, phosphate grains and micas. Detrital clays are present in trace to minor amounts as diffuse laminations. Some unstable rock fragments have been deformed into pseudomatrix. Authigenic minerals include quartz overgrowths, carbonate cements (calcite, siderite and ferroan dolomite), pyrite and clays.

The sample is a fine-grained, moderately sorted sandstone. Average grain size is about 160 microns. Elongate grains exhibit a very slight preferred orientation. Detrital grains are mostly subangular to round and have long to tangential grain-to-grain contacts. Some 'floating” grainto-grain contacts are observed.

The rock has minor amounts of clay cements. Clay content (detrital and authigenic) is 2 percent of the whole rock by XRD. Authigenic clay minerals present in the examined samples are mostly kaolinite and chlorite with trace amounts of $\quad$ B- 6 smectite and illite. Authigenic clays are 
present as grain-coating, pore-lining and pore-filling minerals. Detrital clays appear to be illitic (SEM observations).

Minor quartz overgrowths are observed at grain contacts. When found, quartz overgrowth cement is observed as euhedral crystals that coat detrital grains. Other trace, authigenic minerals include grain-replacive and pore-filling calcite and ferroan dolomite (ankerite), pyrite and siderite.

At 4860.1 feet, routine porosity and permeability measurements report porosity to be $19.3 \%$ and klinkenberg permeability to be 248 md. Intergranular pores are common and average about 80 microns in diameter. Secondary dissolution pores range up to 400 microns and average around 150 microns. Microporosity associated with the clays are also observed.

\section{X-ray Diffraction Analysis \\ By Weight Percent}

\begin{tabular}{|c|c|c|c|c|c|c|c|c|c|c|c|}
\hline $\begin{array}{c}\text { Depth } \\
\text { (feet) }\end{array}$ & 胥 & 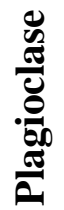 & $\frac{b}{\frac{\pi}{0}}$ & $\frac{\mathscr{J}}{\frac{\pi}{3}}$ & 苞 & مُ & $\begin{array}{l}\text { Total } \\
\text { Clays }\end{array}$ & 苞 & 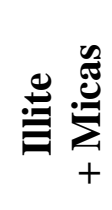 & 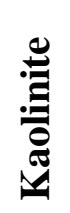 & ڤ્气 \\
\hline & $\%$ & $\%$ & $\%$ & $\%$ & $\%$ & $\%$ & $\%$ & $\%$ & $\%$ & $\%$ & $\%$ \\
\hline 4830 & 89 & 5 & 2 & $\mathrm{tr}$ & $\operatorname{tr}$ & 1 & 3 & 1 & 2 & 0 & 0 \\
\hline 4861 & 96 & 2 & tr & $\operatorname{tr}$ & $\operatorname{tr}$ & $\operatorname{tr}$ & 2 & 1 & $\operatorname{tr}$ & 1 & $\operatorname{tr}$ \\
\hline
\end{tabular}




\section{KN ENERGY}

HUNTSMAN STORAGE NO. 26

CHEYENNE, NEBRASKA

FILE NO.: SL5757

\section{SAMPLE DATA SHEET}

\section{DEPTH: 4830 FEET}

Rock Name: Sublitharenite

Textural Maturity: Submature

Average Grain Size: $95 \mu \mathrm{m}$ (very fine sand)

Porosity Types: Intergranular, dissolution and microporosity

Measured Porosity: $17.9 \%$

Measured Klinkenberg Permeability: 38.5 md

Average Pore Diameter:

Sorting: Moderate to well

Intergranular: $50-70 \mu \mathrm{m}$

Dissolution: $100 \mu \mathrm{m}$ (up to $250 \mu \mathrm{m}$ )

Total Clay Content (by XRD): $3 \%$

Roundness: Subangular to subround

Contacts: Long to tangential, some floating

Detrital Grains

Quartz

Feldspars

Rock fragments

(argillaceous)

Micas

Chert

Organic material

Accessory minerals (zircon \& tourmaline)

Detrital Clays

Abundant Moderate Minor Trace

Authigenic Minerals

Quartz overgrowths

$\mathrm{X}$

Calcite

Ankerite/Ferroan dolomite

Pyrite

Authigenic clays

$\mathrm{X} \quad \mathrm{X}$

$\mathrm{X}$

$\begin{array}{cc}\mathrm{X} & \\ \mathrm{X} & \mathrm{X} \\ & \mathrm{X} \\ & \mathrm{X} \\ & \mathrm{X}\end{array}$

$\mathrm{X}$

$\begin{array}{ccc} & & X \\ & X & X \\ X & X & \\ X & \end{array}$

Observations: Elongate grains show a slight preferred orientation. A zone along one edge of the thin section suggests a Fe-calcite cemented lamina. This sample is very slightly laminated. A possible ooid is also found. Some ductile grains have been deformed into pseudomatrix. Pyrite is found replacing organic stringers. Authigenic minerals (including clays) are observed filling pores and coating grains. 
KN ENERGY

HUNTSMAN STORAGE NO. 26

CHEYENNE, NEBRASKA

FILE NO.: SL5757

\section{THIN SECTION MICROSCOPY — 4830 FEET}

\section{Captions for photos on facing page}

from top (1) to bottom (2)

Figure 1 This is an overview of a very fine-grained, moderately to well sorted sandstone. Intergranular pores are common and on the order of 50 to 70 microns in diameter. Detrital grains include quartz, chert, micas, feldspars and argillaceous rock fragments. This sample appears to be slightly laminated.

Thin section, plane polarized light, 40X

|-------------| $500 \mu \mathrm{m}$

Figure 2 In this high-magnification photomicrograph, quartz overgrowth cement has coated many of the detrital grains. Notice the authigenic pore-lining and partially pore-filling clays. Black, opaque minerals in this view are pyrite.

Thin section, plane polarized light, 200X $100 \mu \mathrm{m}$ 

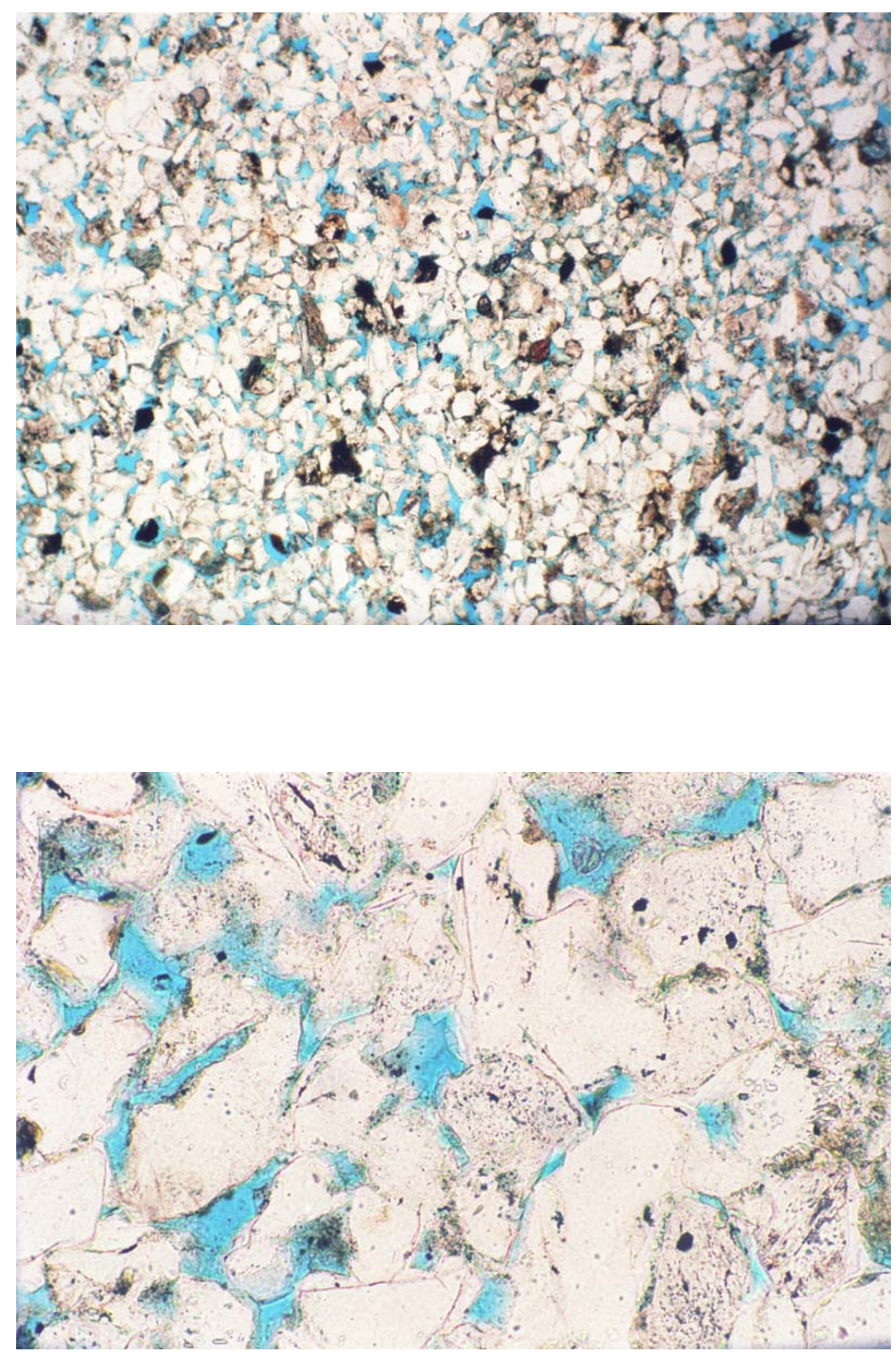


\author{
KN ENERGY \\ HUNTSMAN STORAGE NO. 26 \\ CHEYENNE, NEBRASKA \\ FILE NO.: SL5757
}

THIN SECTION MICROSCOPY — 4830 FEET

Captions for photos on facing page

from top (1) to bottom (2)

Figure 3 Highlighted in this high-magnification photo is the pore-filling ferroan dolomite (ankerite) cement. Notice it has been stained a bluish-purple color. Small brown crystals are siderite.

Thin section, plane polarized light, 200X

|------------| $100 \mu \mathrm{m}$

Figure $4 \quad$ At this location, authigenic, pore-filling and grain-coating clays are evident. Most of the clays in this view appear to be chlorite.

Thin section, plane polarized light, 100X

$|------------| \mid 200 \mu m$

B-11 

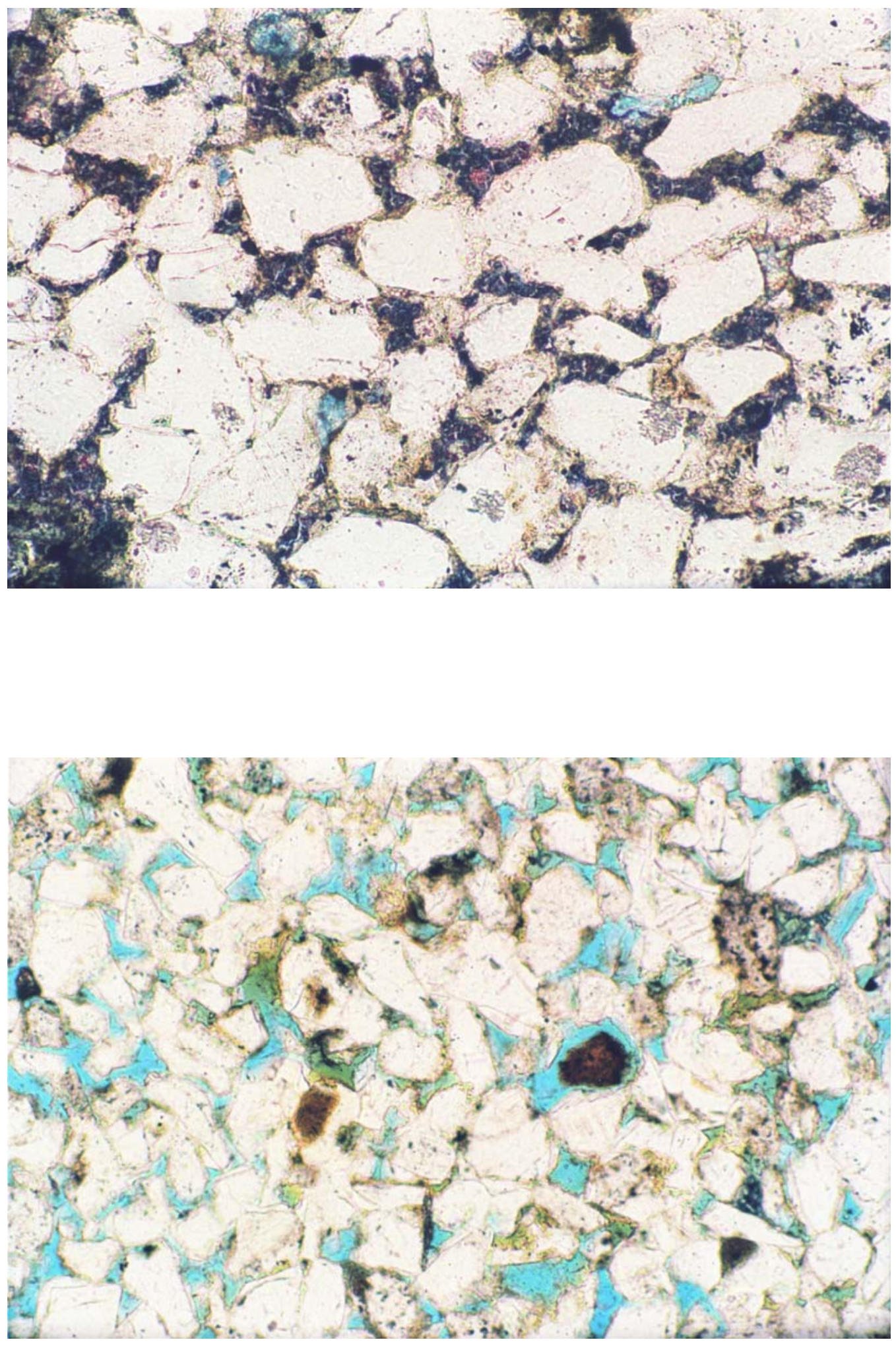
KN ENERGY

HUNTSMAN STORAGE NO. 26

CHEYENNE, NEBRASKA

FILE NO.: SL5757

SCANNING ELECTRON MICROSCOPY — 4830 FEET

Captions for photos on facing page

from top (3) to bottom (4)

Figure 1 This is an overview of a very fine to fine-grained, well sorted sandstone. Quartz is the dominant cement and occurs as euhedral overgrowths coating detrital grains. Authigenic clays are also present in minor to moderate amounts. Open pores are common and on the order of less than 50 microns in diameter.

Scanning Electron Microscopy, 120X

Figure 2 Pore-filling, authigenic kaolinite and pore-bridging illite clays are observed occluding an intergranular pore in this photomicrograph. Quartz overgrowth cement has also contributed to porosity loss in this sample.

Scanning Electron Microscopy, 800X 

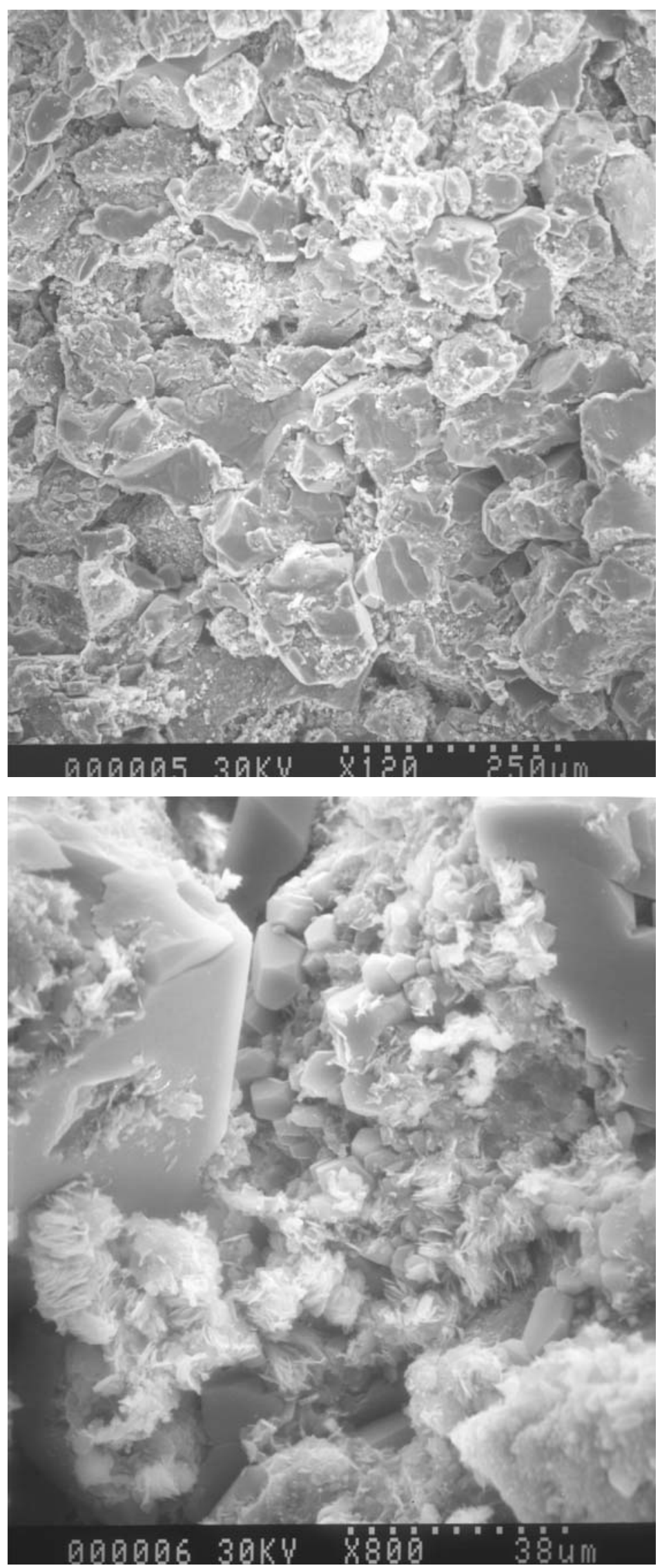

B-14 


\section{KN ENERGY}

HUNTSMAN STORAGE NO. 26

CHEYENNE, NEBRASKA

FILE NO.: SL5757

\section{SAMPLE DATA SHEET}

\section{DEPTH: 4860.1 FEET}

Rock Name: Sublitharenite to Quartzarenite

Textural Maturity: Submature

Average Grain Size: $160 \mu \mathrm{m}$ (fine sand)

Porosity Types: Intergranular, dissolution and microporosity

Measured Porosity: $19.3 \%$

Measured Klinkenberg Permeability: 248 md

Average Pore Diameter:

Sorting: Moderate

Intergranular: $80 \mu \mathrm{m}$

Dissolution: $150 \mu \mathrm{m}$ (up to $400 \mu \mathrm{m}$ )

Roundness: Subangular to round

Total Clay Content (by XRD): $2 \%$

Contacts: Long to tangential, some floating

Detrital Grains

Quartz

Feldspars

Rock fragments

(argillaceous)

Micas

Chert

Phosphate grains

Moderate Minor Trace

Accessory minerals (zircon \& tourmaline)

Detrital Clays

Abundant Moderate Minor Trace

Authigenic Minerals

Quartz overgrowths

Calcite

Ankerite/Ferroan dolomite

$\mathrm{X}$

Siderite

Pyrite

Authigenic clays

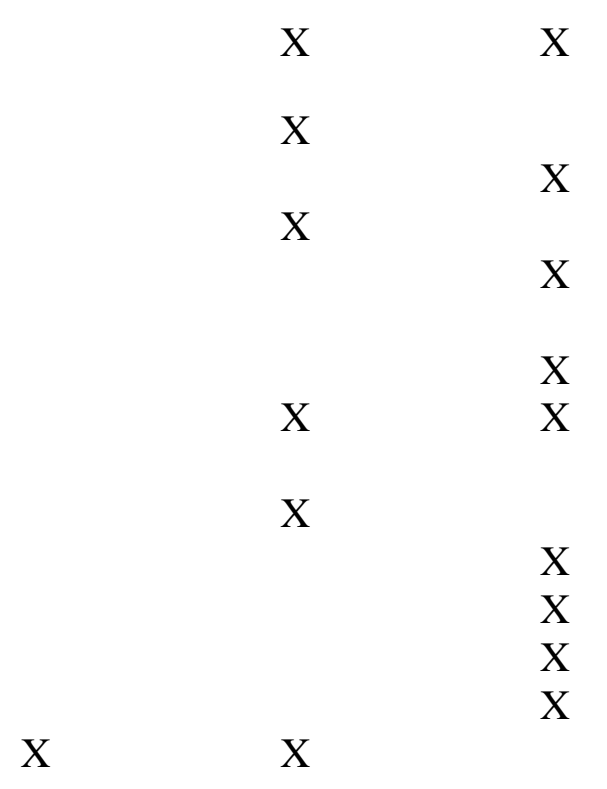

Observations: Diffuse laminations are observed and some elongate grains exhibit a preferred orientation. Pseudomatrix is also evident. Some detrital grains show fracturing. Authigenic clays are observed filling pores and coating grains. 
KN ENERGY

HUNTSMAN STORAGE NO. 26

CHEYENNE, NEBRASKA

FILE NO.: SL5757

\section{THIN SECTION MICROSCOPY — 4860.1 FEET}

\section{Captions for photos on facing page}

from top (1) to bottom (2)

Figure 1 This is an overview of fine-grained, moderately sorted sandstone. Open pores are found in moderate amounts. Intergranular pore diameters average about 80 microns while secondary dissolution pores range up to 400 microns across. Diffuse laminations are also evident.

Thin section, plane polarized light, 40X

|--------------| $500 \mu \mathrm{m}$

Figure 2 In this high-magnification view, secondary, dissolution pores are highlighted. Also observed here are authigenic pore-lining and grain-coating clays.

Thin section, plane polarized light, 100X $200 \mu \mathrm{m}$ 

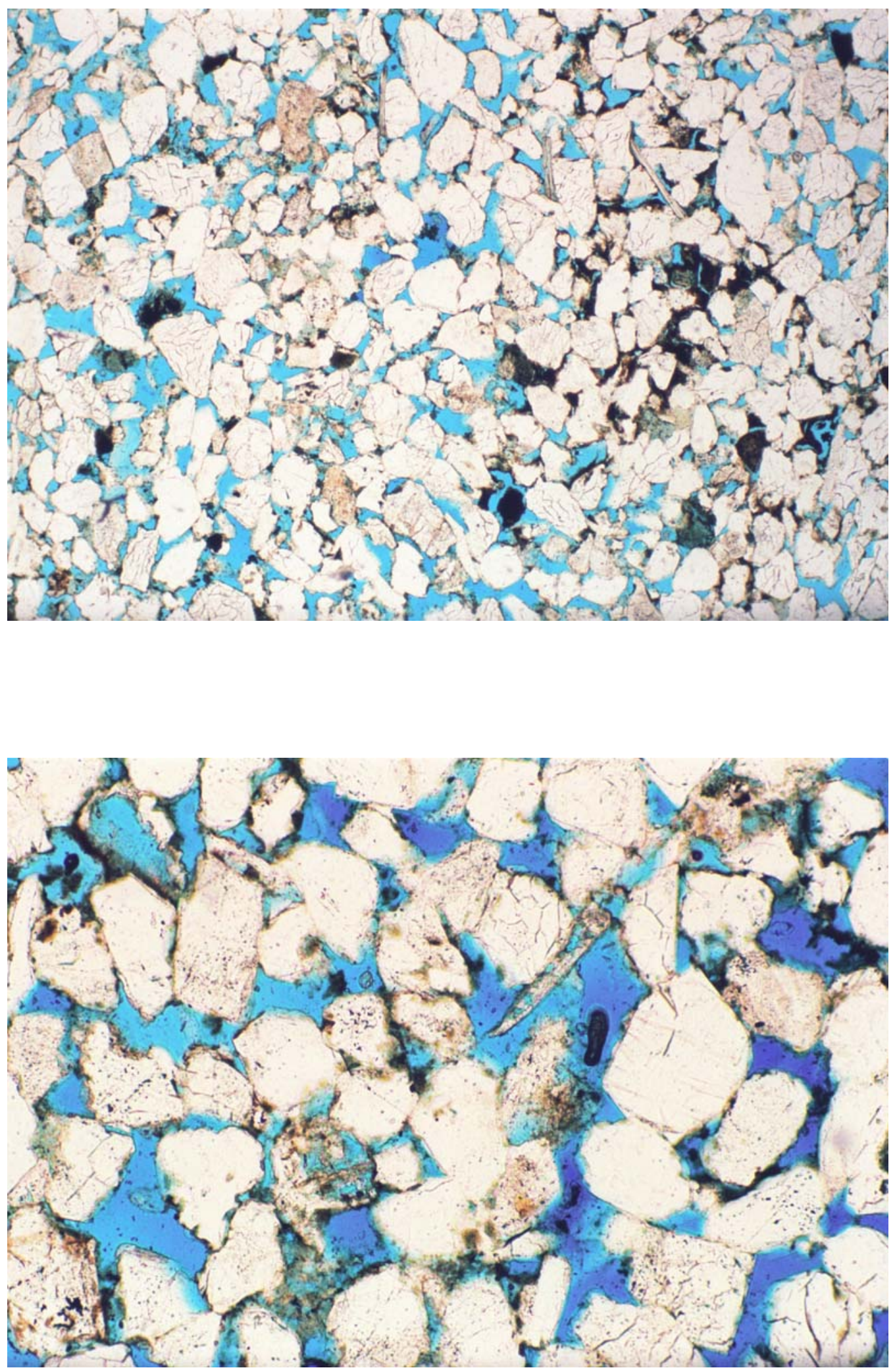


\author{
KN ENERGY \\ HUNTSMAN STORAGE NO. 26 \\ CHEYENNE, NEBRASKA \\ FILE NO.: SL5757
}

THIN SECTION MICROSCOPY — 4860.1 FEET

Captions for photos on facing page

from top (1) to bottom (2)

Figure 3 Authigenic pore-filling kaolinite is found in the upper left corner of this photomicrograph. Also evident in this image are euhedral, grain-coating quartz overgrowth cement. Notice the authigenic, pore-lining clays.

Thin section, plane polarized light, 200X

|------------| $100 \mu \mathrm{m}$

Figure 4 In addition to the authigenic, pore-lining and pore-filling clays, pore-filling, ironrich dolomite (ankerite) cement is observed near the center of this view. Notice the slightly fractured nature to the detrital quartz grains.

Thin section, plane polarized light, 200X

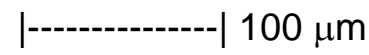

B-18 

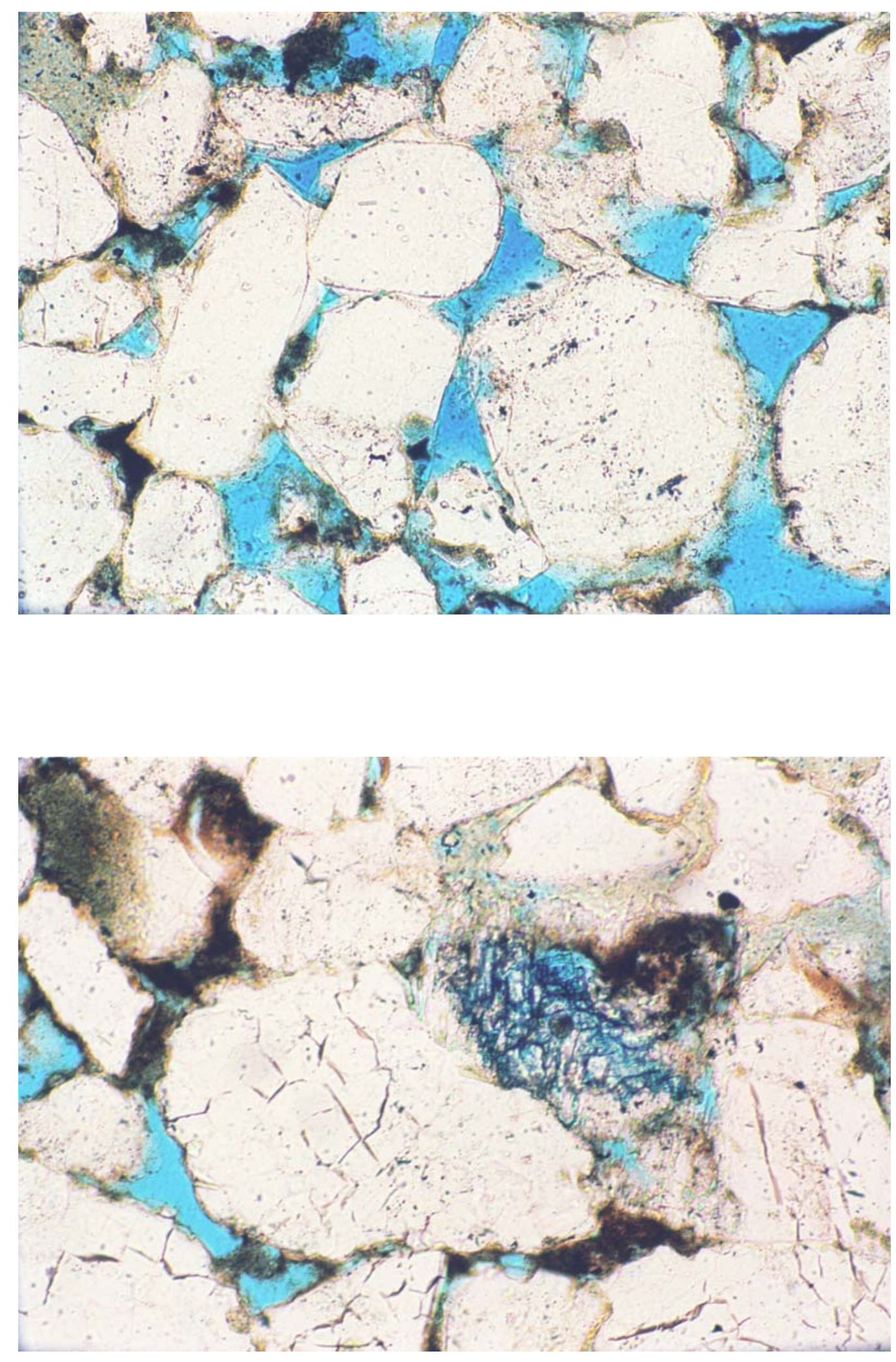
KN ENERGY

HUNTSMAN STORAGE NO. 26

CHEYENNE, NEBRASKA

FILE NO.: SL5757

SCANNING ELECTRON MICROSCOPY — 4860.1 FEET

Captions for photos on facing page

from top (3) to bottom (4)

Figure 1 This is an overview of a fine to medium-grained, well sorted sandstone. Quartz overgrowths are abundant and grain-coating/pore-lining illite clays are common. Open pores are also common and average about 80 to 90 microns across.

Scanning Electron Microscopy, 110X

Figure 2 Authigenic kaolinite is highlighted at this location. Notice the characteristic crystal morphology and the microporosity associated with this clay. Some pore-bridging illite clays can also be found in this view. At high production rates, looselyattached kaolinite can become mobile and migrate to pore throats.

Scanning Electron Microscopy, 800X 

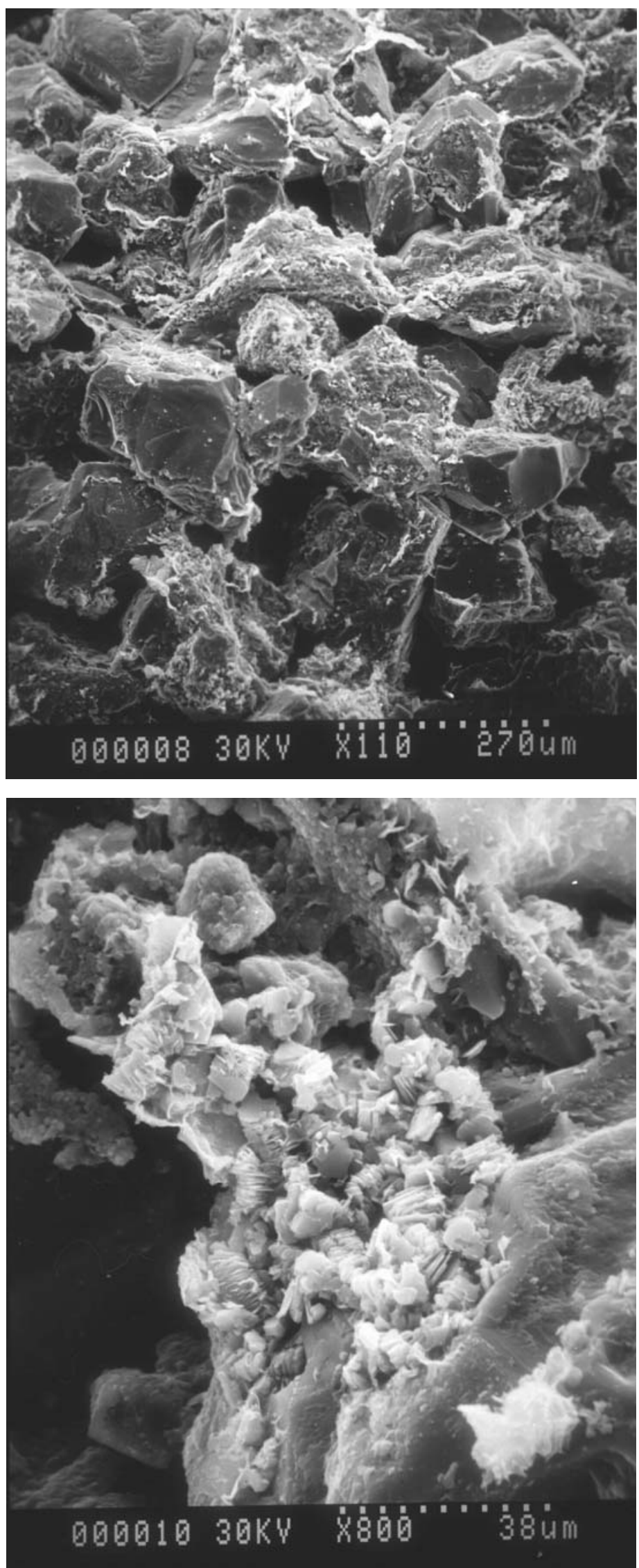

B-21 


\section{Appendix C}

\section{Petrographic Analysis of the A-2 Caronate from the Overisel Storage Field}




\title{
PETROGRAPHIC ANALYSIS OF THE A-2 CARBONATE FROM THE OVERISEL STORAGE FACILITY OVERISEL, MICHIGAN
}

Prepared for:

\author{
ADVANCED RESOURCES INTERNATIONAL \\ 1110 N. GLEBE ROAD \\ ARLington, VA 22201
}

Prepared by:

\author{
STIM-LAB, INC. \\ 7406 NORTH HWY 81 \\ DUNCAN, OKLAHOMA 73533-1644
}

P.O. NUMBER: VERBAL/

FILE NUMBER: SL 5757

SEPTEMBER 30, 2002

\begin{abstract}
ALL INTERPRETATIONS ARE OPINIONS BASED ON INFERENCES FROM SAMPLES AND LOGS, WHICH WERE SUPPLIED. WE CANNOT, AND DO NOT, GUARANTEE THE ACCURACY OR CORRECTNESS OF ANY INTERPRETATIONS, AND WE SHALL NOT, EXCEPT IN THE CASE OF GROSS OR WILLFUL NEGLIGENCE ON OUR PART, BE LIABLE OR RESPONSIBLE FOR ANY LOSS, COSTS, DAMAGES OR EXPENSES INCURRED OR SUSTAINED BY ANYONE RESULTING FROM ANY INTERPRETATION MADE BY ANY OF OUR OFFICERS, AGENTS OR EMPLOYEES. THESE INTERPRETATIONS ARE ALSO SUBJECT TO OUR GENERAL TERMS AND CONDITIONS AS SET OUT IN OUR CURRENT PRICE SCHEDULE.
\end{abstract} Application of Carbon Dioxide in Natural Gas Storage Wells” 


\section{CORE ANALYSIS REPORT}

\section{INTRODUCTION}

Routine core analysis was performed on one conventional core sample from the Consumers Energy Overisel Storage Facility, Overisel, Michigan. Results are presented in this report.

\section{SAMPLE PREPARATION}

PLUG PREPARATION: The core plugs were drilled with a 1" diameter diamond tipped core barrel cooled with water. The plugs were trimmed using a saw equipped with diamond blades. The plugs were faced with a diamond-facing tool to provide right circular cylinders.

SAMPLE CLEANING: The samples were extracted of hydrocarbons in a soxhlet extractor. Toluene was used as the refluxing solvent. Extraction was continued until the returning solvent was clear.

SAMPLE DRYING: The samples were dried in a convection oven at $240^{\circ} \mathrm{F}$ for 24 hours.

\section{POROSITY AND PERMEABILITY MEASUREMENTS WITH THE CMS-300}

Conventional core samples are analyzed using the CMS-300 automated core measurement system that incorporates a porosimeter and permeameter into one instrument. The CMS-300 system performs computer-controlled, unsteady state, pressure-transient measurements of reservoir rock pore volumes, porosity, Klinkenberg permeability, Forchheimer inertial factor and Klinkenberg slip factor at up to eight specified confining pressures between 500 psi and 10,000 psi. This allows measurements to be made at overburden pressures more representative of reservoir conditions. Helium is the test gas used.

POROSITY: Porosity is defined as the ratio of the pore volume to the bulk volume of material.

Porosity $=\frac{\text { Pore Volume (Volume Of Helium Injected Into the Pore Space by the CMS) }}{\text { Bulk Volume (Volume Of The Plug As Determined By A Fowler Ultra-Call Mark III }}$

This equation corrects for bulk volume reduction as overburden pressure is applied. 
PERMEABILITY: Permeability is a measure of the ability of a porous material to transmit fluid.

Kinf $=$ Klinkenberg corrected permeability. Equivalent, non-reactive, liquid permeability determined by the CMS at up to eight designated, net-overburden, confining stresses. This is an improved flow capacity indicator since gas slippage effects present at low laboratory pore pressure (and not at reservoir conditions) have been eliminated.

Kair $=$ A calculated air permeability approximating historical core analysis permeability data. Kair is an optimistic value. Low pressures in historical laboratory measurements result in gas slippage not present at reservoir conditions and create artificially high permeability values.

GRAIN DENSITY: Calculated grain densities were obtained utilizing bulk volume and pore volume measurements and clean, dry sample weights. Grain densities were checked against lithology standards.

\section{Routine Core Analysis Results}

\begin{tabular}{|c|c|c|c|c|}
\hline \multirow[b]{2}{*}{$\begin{array}{c}\text { Sample } \\
\text { ID }\end{array}$} & \multirow{2}{*}{$\begin{array}{c}\text { Helium } \\
\text { Porosity } \\
\% \\
\end{array}$} & \multicolumn{2}{|c|}{ Permeability (800psi) } & \multirow{2}{*}{$\begin{array}{c}\text { Grain } \\
\text { Density } \\
\text { g/cc }\end{array}$} \\
\hline & & $\begin{array}{l}\text { Air } \\
\text { (md) }\end{array}$ & $\begin{array}{c}\text { Klinkenberg } \\
\text { (md) }\end{array}$ & \\
\hline A-2 Carbonate & 10.0 & 0.100 & 0.061 & 2.83 \\
\hline
\end{tabular}




\section{PETROGRAPHic report}

\section{INTRODUCTION}

Thin section petrography, scanning electron microscopy with energy dispersive spectrometry (SEM/EDS) and X-ray diffraction analysis were performed on one conventional core sample from the Consumers Energy Overisel Storage Facility, Overisel, Michigan. The purpose of this study is to describe the mineralogical and textural characteristics of the sample.

\section{METHOD}

\section{Thin Section Petrography}

Thin section petrography provides the best overall characterization of the rock samples. Selected samples are impregnated with a low viscosity, blue epoxy prior to mounting on a glass slide. After mounting, the samples are ground to a uniform thickness of 30 microns. Thin sections have been stained with Alizarin Red-S and potassium ferricyanide stains for easier identification of calcite and ferroan carbonate minerals.

Most mineral and amorphous phases can be identified, and visual estimates of porosity types are possible from the thin sections. Grain size, sorting and other textural characteristics can also be accurately estimated. Observations are documented in the data sheets and photomicrographs presented later in the report.

\section{Scanning Electron Microscopy}

The scanning electron microscope (SEM) provides a three-dimensional view of grain surfaces and pores. Freshly fractured surfaces of selected sample are used for SEM analysis. The samples are sputter coated with gold-palladium and photographs document the observations. High magnifications, coupled with energy dispersive x-ray spectrometry (EDS), allow for the identification of clay-size materials.

\section{X-Ray Diffraction Analysis}

X-ray diffraction analysis (XRD) provides excellent qualitative mineral identification and semiquantitative compositions by weight of the crystalline components of the rock samples. A complete procedure requires separate analysis of the "bulk" sample and the "clay" fraction. A table of compositions determined by XRD is presented in the report.

The representative samples selected for "bulk" analysis are first cleaned of surface contamination and ground until all of the material passes through a 200-mesh screen. Next, the sample is ground in acetone to produce a uniform powder of 10 to 50 micron particles. The powdered rock is lightly packed in a sample holder and scanned from 2 to 45 degrees 2-theta by step scanning 0.05 degrees 2 -theta for 5 seconds. The counts at each step are directly collected by and stored in the computer for later analysis.

Analysis of the clay fraction begins by disaggregation of fine-grained material in water with ultrasonication. The suspended material is centrifuged to separate the particles by size. Particles less than 5 microns in size are filtered out of suspension. The filtered clays are transferred to a glass slide and scanned from 2 to 40 degrees 2-theta by step scanning as above. If swelling clays appear to be present, they are confirmed by saturating the clays with ethylene glycol vapor. The slide is then rescanned. 


\section{PETROGRAPHIC DESCRIPTION}

\section{a-2 Carbonate - dolostone}

The sample is classified as a crystalline dolostone (Dunham, 1962). The average crystal size for the dolomite crystals is around 10 to 20 microns (very finely crystalline). Allochemical constituents are not observed. Terrigenous grains in the dolostones include minor to trace amounts of quartz and plagioglase feldspars. Organics and other insoluble materials are concentrated along stylolites.

The most common authigenic mineral is hypidiotopic to idiotopic dolomite, which has replaced and destroyed most of the original depositional textures. Authigenic quartz occurs in trace to minor amounts as a pore-filling mineral. Anhydrite is observe in the thin section as a localized pore-filling cement; but is not detected by X-ray diffraction analysis. Pyrite is found in trace amounts in this sample.

Clay minerals are found in trace amounts as a pore lining, and some clays are associated with stylolites. X-ray diffraction analysis shows the clays to be mostly illite.

Measured helium porosity for this sample is 10.0 percent. Air permeability is $0.100 \mathrm{md}$, and Klinkenburg permeability is $0.061 \mathrm{md}$. Thin section analysis indicates that most of the porosity is likely due to intercrystalline micropores, with only a few isolated, secondary dissolution pores observed. One large dissolution pore ranges up to 1300 microns across, but most dissolution pores are about 100 to 150 microns in diameter. Some stylolitic porosity (secondary) is also evident.

\section{X-ray Diffraction Analysis \\ By Weight Percent}

\begin{tabular}{|c|c|c|c|c|c|}
\hline & Dolomite & Quartz & Plagioclase & $\begin{array}{c}\text { Total } \\
\text { Clay }\end{array}$ & Illite \\
\hline & $\%$ & $\%$ & $\%$ & $\%$ & $\%$ \\
\hline A-2 Carbonate & 99 & 1 & $\operatorname{tr}$ & $\operatorname{tr}$ & $\operatorname{tr}$ \\
\hline
\end{tabular}


CONSUMERS ENERGY

OVERISEL STORAGE FACILITY

OVERISEL, MICHIGAN

FILE NO.: SL5757

SAMPLE DATA SHEET

DEPTH: A-2 CARBONATE - DOLOSTONE

Measured Air Permeability: 0.100 md

Measured Porosity: $\quad 10.0 \%$

Porosity Types: $\quad$ Some dissolution and stylolitic; also microporosity associated with matrix

Pore Diameters Average: Intercrystalline micropores are less than 10 microns

Sorting/Angularity: N/A

Range: Dissolution pores up to 1300 microns, but isolated

Detrital Grains:

Minor quartz; trace feldspars

Detrital Clays:

None observed

Total Clay by XRD: $\quad$ Trace - mostly illite

Carbonate Constituents \& No allochems are observed

Allochems:

Authigenic Cements

Abundant dolomite (microcystalline matrix); minor quartz (replacive, pore-filling); minor to trace pyrite and possible siderite; localized pore-filling anhydrite associated with dissolution pores

Authigenic Clays:

Trace - pore-lining, mostly illite

Average Crystal Size:

Aphanocrystalline matrix; 10 to 20 microns

Dolomitic Textures

Hypidiotopic to idiotopic;; some xenotopic

Structures \& Other

Features:

Stylolites are observed. Amplitude is about $5 \mathrm{~mm}$.

Observations:

Some organics are observed along the large stylolite. Some dissolution pores are developed along the stylolites. 
Figure 1 This is an overview of a crystalline dolomite. A stylolite with an amplitude of around $5 \mathrm{~mm}$ is distinguished by the concentration of organics and insoluble material. Although a few isolated secondary dissolution pores are observed, most of the porosity is due to microporosity associated with the dolomite matrix. Thin section, plane polarized light, 20X

Figure 2 This is a similar view of the previous sample. Notice the development of secondary porosity along the stylolite.

Thin section, plane polarized light, 40X 

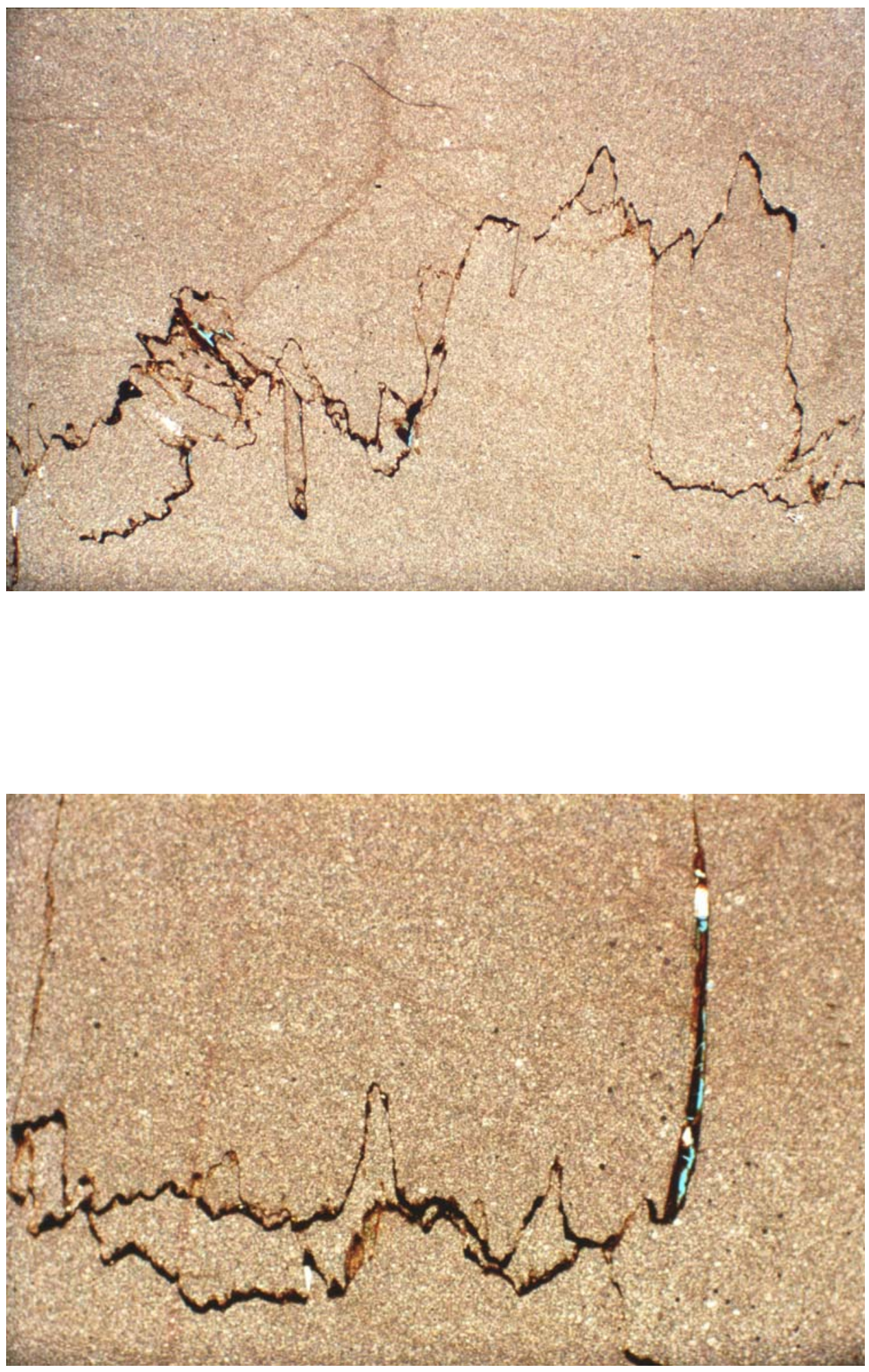
CONSUMERS ENERGY

OVERISEL STORAGE FACILITY

OVERISEL, MICHIGAN

FILE NO.: SL5757

\section{THIN SECTION MICROSCOPY — A-2 CARBONATE}

\section{Captions for photos on facing page}

from top (3) to bottom (4)

Figure 3 Small dissolution pores (on the order of 150 microns) are highlighted in this view. This is also a good view of the dolomite matrix. Dolomite crystals are typically 10 to 20 microns across.

Thin section, plane polarized light, 200X

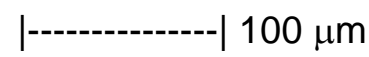

Figure $4 \quad$ Anhydrite is found partially filling a large, secondary dissolution pore. Also observed are trace amounts of authigenic clays.

Thin section, plane polarized light, 100X

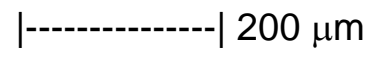

C-10 

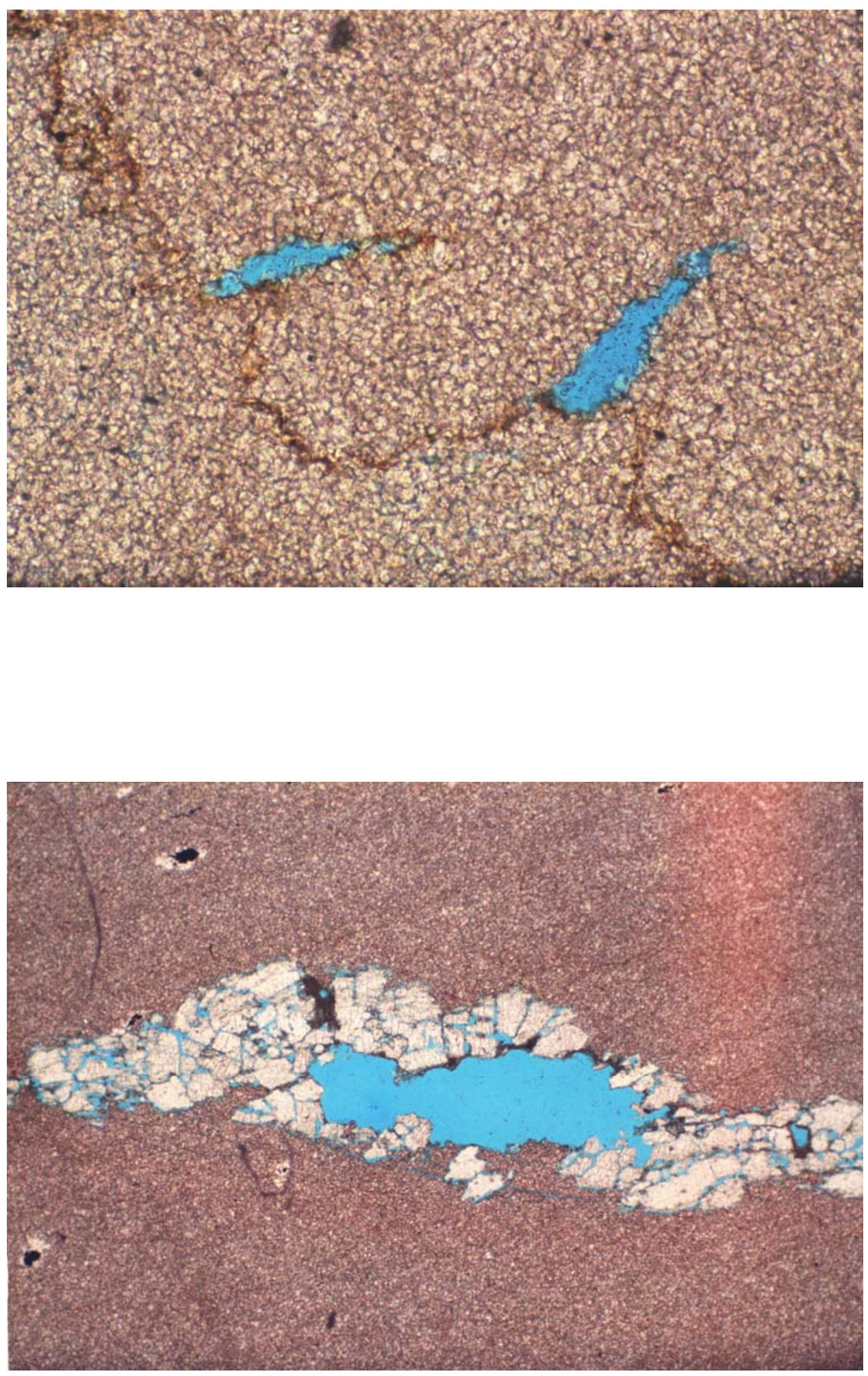
CONSUMERS ENERGY

OVERISEL STORAGE FACILITY

OVERISEL, MICHIGAN

FILE NO.: SL5757

SCANNING ELECTRON MICROSCOPY — A-2 CARBONATE

Captions for photos on facing page

from top (1) to bottom (2)

Figure 1 In this high-magnification photomicrograph the dolomite matrix is highlighted. Notice the small rhombs. This dolomite texture is hypidiotopic to idiotopic. Also notice the intercrystalline microporosity.

Scanning Electron Microscopy, 700X

Figure 2 Some pore-filling quartz cement is found at this location. XRD analysis shows quartz to be a trace to minor mineral.

Scanning Electron Microscopy, 500X

C-12 
OVERISEL STORAGE FACILITY
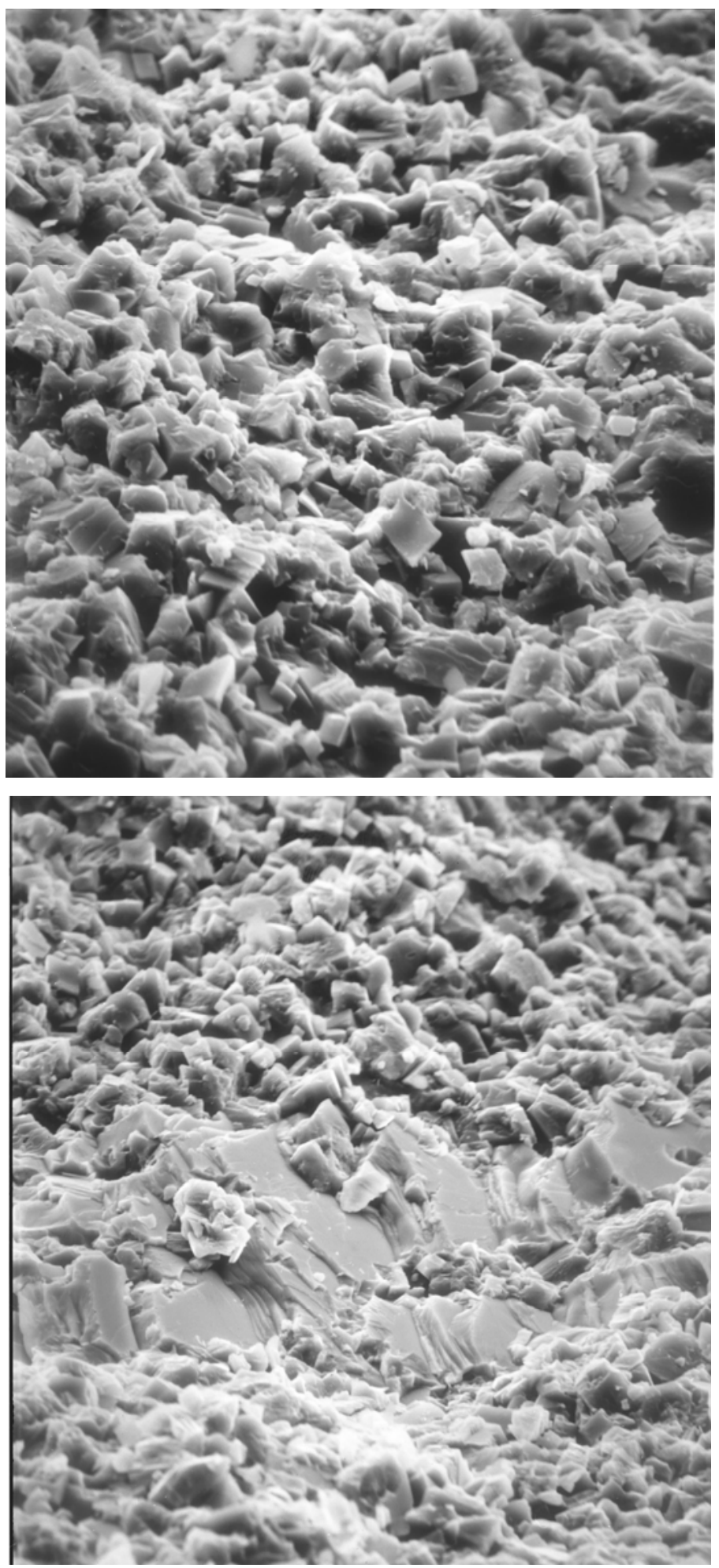